San Jose State University

SJSU ScholarWorks

Master's Theses

Master's Theses and Graduate Research

1993

\title{
Investigation into toughness improvement in graphite/epoxy composites using teflon powder
}

Daniel A. Chafey

San Jose State University

Follow this and additional works at: https://scholarworks.sjsu.edu/etd_theses

\section{Recommended Citation}

Chafey, Daniel A., "Investigation into toughness improvement in graphite/epoxy composites using teflon powder" (1993). Master's Theses. 522.

DOI: https://doi.org/10.31979/etd.x29v-a893

https://scholarworks.sjsu.edu/etd_theses/522

This Thesis is brought to you for free and open access by the Master's Theses and Graduate Research at SJSU ScholarWorks. It has been accepted for inclusion in Master's Theses by an authorized administrator of SJSU ScholarWorks. For more information, please contact scholarworks@sjsu.edu. 


\section{INFORMATION TO USERS}

This manuscript has been reproduced from the microfilm master. UMI films the text directly from the original or copy submitted. Thus, some thesis and dissertation copies are in typewriter face, while others may be from any type of computer printer.

The quality of this reproduction is dependent upon the quality of the copy submitted. Broken or indistinct print, colored or poor quality illustrations and photographs, print bleedthrough, substandard margins, and improper alignment can adversely affect reproduction.

In the unlikely event that the author did not send UMI a complete manuscript and there are missing pages, these will be noted. Also, if unauthorized copyright material had to be removed, a note will indicate the deletion.

Oversize materials (e.g., maps, drawings, charts) are reproduced by sectioning the original, beginning at the upper left-hand corner and continuing from left to right in equal sections with small overlaps. Each original is also photographed in one exposure and is included in reduced form at the back of the book.

Photographs included in the original manuscript have been reproduced xerographically in this copy. Higher quality $6 " \mathrm{x}$ " 9 " black and white photographic prints are available for any photographs or illustrations appearing in this copy for an additional charge. Contact UMI directly to order.

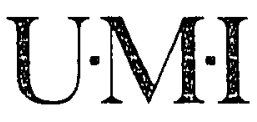

University Microfilms internatıonal

A Bell \& Howell Information Company

300 North Zeeb Road. Ann Arbor. MI 48106-1346 USA

$313: 761-4700 \quad 800: 521-0600$ 
Investigation into toughness improvement in graphite/epoxy composites using Teflon powder

Chafey, Daniel Allen, M.S.

San Jose State University, 1993

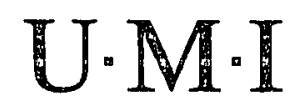

300 N. Zeeb Rd.

Ann Arbor, MI 48106 


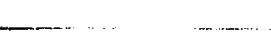




\title{
INVESTIGATION INTO TOUGHNESS IMPROVEMENT IN GRAPHITE/EPOXY COMPOSITES USING TEFLON POWDER
}

\author{
A Thesis \\ Presented to \\ The Faculty of the Department of Materials Engineering \\ San Jose State University \\ In Partial Fulfillment \\ of the Requirements for the Degree \\ Master of Science
}

By

Daniel A. Chafey

May, 1993 
APPROVED FOR THE DEPARTMENT OF MATERIALS ENGINEERING

$\underset{\text { Dr. Gina Selvaduray }}{\text { Gray }}$

Thesis Committee Chairman

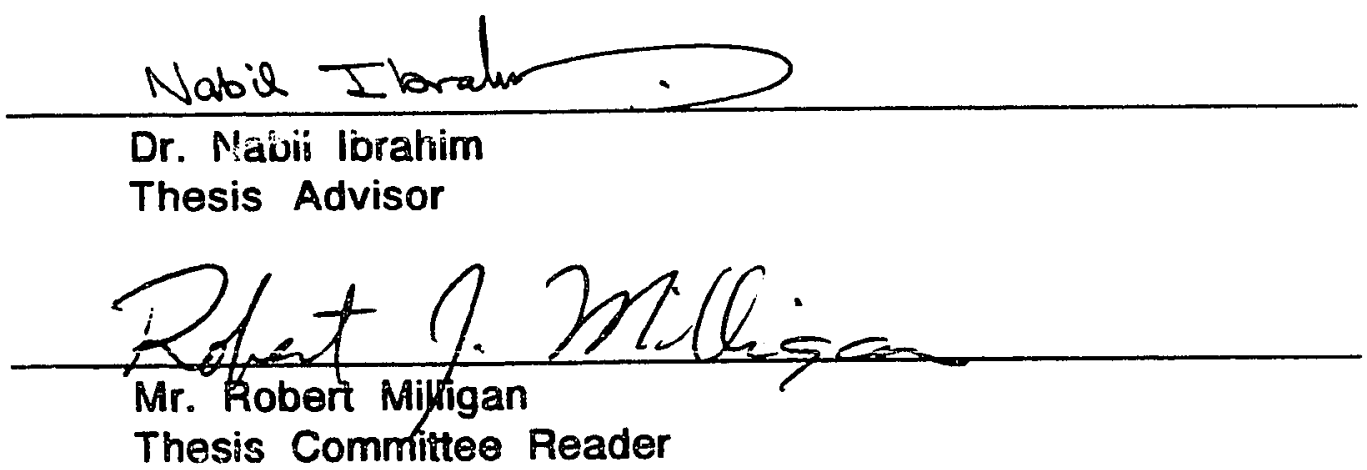

APPROVED FOR THE UNIVERSITY

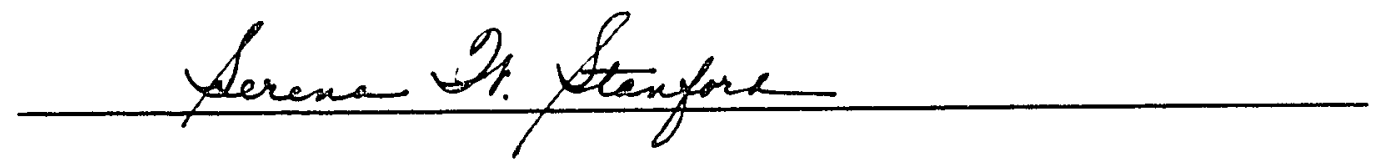




\section{ABSTRACT \\ INVESTIGATION INTO TOUGHNESS IMPROVEMENT \\ IN GRAPHITEEEPOXY COMPOSITES \\ USING TEFLON POWDER}

by Daniel A. Chafey

This project investigates a method of improving composite toughness by additives in the form of Tefion powder. The additives improve energy absorbing mechanisms by providing numerous and small defects for the formation of cracks smaller than the critical crack size. The Teflon provides a ductile phase in the matrix that relieves stress and induces cracks to form convoluted paths as the crack tip reaches sites that will plastically deform. An experiment was conducted using graphite/epoxy composite three point bend specimens. The control samples had virtually no measurable strain after yield. With Tefion additions the samples displayed additional strain. The jailure modes changed from predominantly single cracks, to a mode of multiple cracks forming delamination before failure. The additional strain is important because it increased the nonlinear portion of the stress-strain curve, delaying the propagation of catastrophic cracks, and the material becomes more tolerant to limited damage preceding total failure. 


\section{ACKNOWLEDGMENTS}

Sincere gratitude is expressed to Dr. Guna Selvaduray, Dr. Nabit Ibrahim, and Mr. Robert Milligan for their valuable assistance and advise on this thesis.

Recognition is also given to Lockheed Missiles and Space Co., Inc., for the use of facilities in the Materials and Processes Engineering Advanced Technology Laboratory. Specifically, I would like to thank Gilbert Hennessee, and Patrick McCormick for their valuable assistance in providing the necessary material, equipment, expertise and guidance, without which this project would not have been possible.

Lastly, but most importantly, I would like to thank Mary Eller, my wife, for countless hours of proofreading and editorial help. She also has provided the understanding, support, and ime I needed to work on this project, which, together with our son, Pongsak, has given me the inspiration to finish. 


\section{TABLE OF CONTENTS}

Abstract page iii

Acknowledgments iv

List of Figures $\mathrm{vii}$

List of Tables $x i$

Chapter 1: Introduction

1

1.1 Composite Design 1

1.2 Toughness in Composites 5

Chapter 2: Previous Investigations in

Toughness 10

2.1 Review of Relevant Investigations 10

2.2 Summary of Previous Investigations 17

Chapter 3: Experimental Objectives 19 Chapter 4: Experimental Details 22

4.1 Raw Materials 23

4.2 Material Preparation 25

4.3 Cure Cycle 30

4.4 Specimen Preparation 34

4.5 Three Point Bend Test 36

4.6 Experimental Test Variables 37

4.7 Data Acquisition System 38

4.8 Method of Calculating Toughness 42 


\section{TABLE OF CONTENTS}

(continued)

Chapter 5: Experimental Results 44

5.1 Test Resuits 45

5.2 Toughness and Damage Tolerance Evaluation - 57

5.3 Effects on Strength and Flexural Modulus _ 64

5.4 Effects on Panel Thickness and Density _ 68

5.5 Effects on the Mode of Failure 71

Chapter 6: Summary of Significant Results -77

Chapter 7: Conclusions 82

Chapter 8: References 87

Chapter 9: Bibliography 90

Appendix A: Instrumented Mechanical Test

Data for all Specimens 91 


\section{LIST OF FIGURES}

Figure 1. Specific Tensile Modulus and Specific Strength for Various Materials _ page 2

Figure 2. Exploded View of an FRP Laminate __ 4

Figure 3. Planes of Separation in Fiber

Reinforced Composites _ 8

Figure 4. Effect of Interleaving on Impact

Damage Resistance

Figure 5. Fracture Energy and $T_{g}$ Changes

Versus Rubber Content

Figure 6. Delamination Model Showing an Assumed

Fracture Surface Through a Stylized

Hexagonai Array of Fibers

Figure 7. Pull-out Curve For Kevlar Treated

with Acetone

Figure 8. Continuous Fibers Which Fail in the

Crack Plane

Figure 9. HMF 2409/34 Prepreg, with 5HS Satin

Weave Pattern

Figure 10. Prepreg Surface Before Application of

Tefion Powder

Figure 11. Prepreg Surface After Application of $1 \%$

Tefion Powder 


\section{LIST OF FIGURES}

(continued)

Figure 12. Prepreg Surface After Application of $2 \%$

Teflon Powder

Figure 13. Prepreg Surface After Application of $4 \%$ Teflon Powder 28

Figure 14. Prepreg Surface After Application of 6\% Teflon Powder 28

Figure 15. GFRP Lay Up Prepared for Autoclave Cure 31

Figure 16. Four Panel Arrangement on Autoclave Caul Plate 32

Figure 17. Autoclave Cure Cycle 33

Figure 18. Panel Cutting Diagram 35

Figure 19. Three Point Bend Test Specimen 36

Figure 20 Offset Yield Method 41

Figure 21. Stress-Strain Curve for a Warp Direction Specimen from Panel A with 0\% Teflon 53

Figure 22. Stress-Strain Curve for a Warp Direction Specimen from Panel $F$ with $1 \%$ Teflon

Figure 23. Siress-Strain Curve for a Warp Direction Specimen from Panel $P$ with $4 \%$ Teffon 54

Figure 24. Stress-Strain Curve for a Fill Direction Specimen from Panel A with 6\% Tefion 54 


\section{LIST OF FIGURES \\ (continued)}

Figure 25. Stress-Strain Curve for a Fill Direction Specimen from Panel 0 with 2\% Teflon

Figure 26. Stress-Strain Curve for a Fill Direction

Specimen from Panel D with $4 \%$ Tefion

Figure 27. Warp Direction $\Delta \varepsilon$ as a Function of Added

Teflon

Figure 28. Fill Direction $\Delta \varepsilon$ as a Function of Added

Tefion

Figure 29. Warp Direction Fracture Energy as a

Function of Added Tefion 60

Figure 30. Fill Direction Fracture Energy as a

Function of Added Tefion

Figure 31. Warp Direction Total Energy of Failure as a Function of Added Teînon

Figure 32. Fiil Direction Total Energy of Failure as a

Function of Added Teflon

Figure 33. Warp Direction Strength as a Function of Added Teflon 65

Figure 34. Fill Direction Strength as a Function of Added Tefion 66

Figure 35. Warp Direction Flexural Modulus as a Function of Added Teflon 


\section{LIST OF FIGURES \\ (continued)}

Figure 36. Fill Direction Flexural Modulus as a

Function of Added Tefion

Figure 37. Post-Cure Panel Density as a Function of

Added Tefion

Figure 38. Post-Cure Panel Thickness as a Function of Added Teflon

Figure 39. Three Point Bend Specimens Fracture Zone.

Warp Direction, Panel E, 0\% Added Teflon

Figure 40. Three Point Bend Specimens Fracture Zone.

Warp Direction, Panel F, 1.28\% Added Tefion - 72

Figure 41. Three Point Bend Specimens Fracture Zone.

Warp Direction, Panel O, 2.02\% Added Tefion _ 73

Figure 42. Three Point Bend Specimens Fracture Zone.

Warp Direction, Panel H, 4.13\% Added Teflon _ 73

Figure 43. Three Point Bend Specimens Fracture Zone.

Fill Direction, Panel M, 0\% Added Teflon

Figure 44. Three Point Bend Specimens Fracture Zone.

Fill Direction, Panel N, 1.14\% Added Teflon 74

Figure 45. Three Point Bend Specimens Fracture Zone.

Fill Direction, Panel G, 2.17\% Added Tefion 75

Figure 46. Three Point Bend Specimens Fracture Zone.

Fill Direction, Panel D, 4.25\% Added Teffon 75 


\section{LIST OF TABLES}

Table 1. Teflon Concentrations added to Each Panel___ page 30

Table 2. Warp Direction 3-point Bend Test Data___ 46

Table 3. Fill Direction 3-point Bend Test Data___ 47

Table 4. Warp Direction, With Calculations for

Toughness and Damage Tolerance___ 50

Table 5. Fill Direction, With Calculations for

Toughness and Damage Tolerance___ 51 


\section{CHAPTER 1}

\section{INTRODUCTION}

\subsection{Composite Design}

A composite is a physical combination of two or more separate materials, designed to use advantageous properties from each component. In the case of fiber reinforced plastics (FRP), desirable properties of greatest interest usually are high strength, high elastic modulus, and low density. This is important because strong, stiff, and lightweight materials are necessary for many advanced high performance applications. In FRP the fibers provide strength and a high elastic modulus, and the plastic matrix provides cohesiveness and load transfer from fiber to fiber. The construction of FRP composite materials can be tailored such that the fibers carry the majority of the load.

Small diameter graphite fibers are considerably stronger than the bulk material because they can be fabricated nearly defect-free with the highly ordered hexagonal plane parallel to the fiber axis. New grades of graphite fibers have tensile strengths of $5.5 \mathrm{GPa}$, and a elastic moduli of $320 \mathrm{GPa} .(1)$ With a density of $1.8 \mathrm{~g} / \mathrm{cm}^{3}$, graphite fibers fabricated into composite materials provide excellent strength, stiffness, and low weight. The specific strength (strength per specific gravity) and specific tensile modulus of various 
materials is shown in Figure 1. This figure shows the advantages of composites in weight sensitive structures. The composite material properties shown are for unidirectional fibers where strength is maximized.

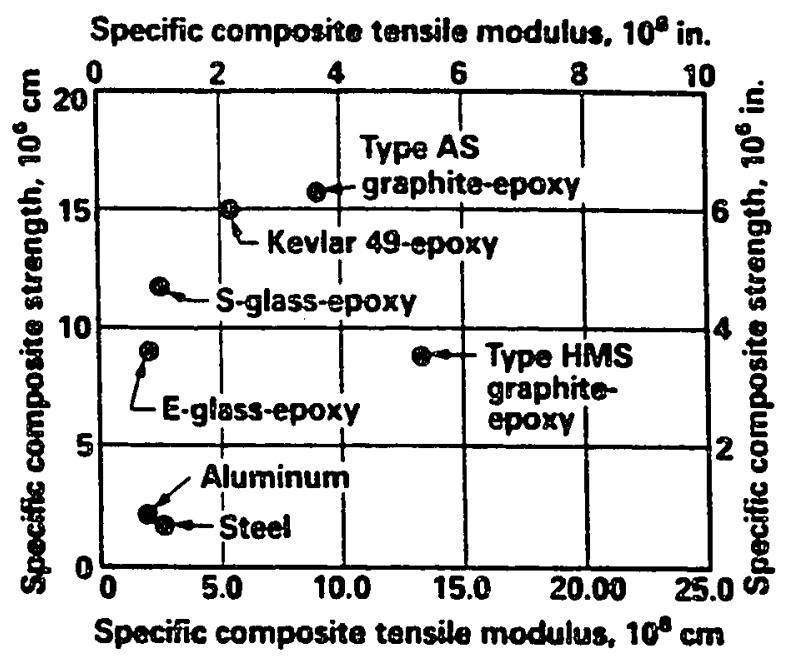

Figure 1. Specific Tensile Modulus and Specific Strength for Various Materials.(2)

The matrix binds the fibers together and acts as the medium to transmit and distribute applied stress to the fibers. The elastic modulus of the matrix is much lower than the fiber, and it is capable of yielding in a plastic manner, allowing the majority of the load to be carried by the fibers. The matrix also acts to protect the fibers from surface damage capable of forming cracks, which may lead to failure at a relatively low stress level. The plastic matrix deters 
the propagation of brittle cracks from fiber to fiber. Even though some individual fibers may fail at relatively low stress levels, premature composite fracture will not occur since the matrix phase acts as a barrier to crack propagation. As individual fibers break, the matrix deforms and redistributes the load to surrounding fibers. It is important that the adhesive bonding strength between fiber and matrix be sufficiently high to maximize the stress transfer and prevent fiber motion. Epoxy resins are used frequently because of their excellent balance of properties such as corrosion and solvent resistance, good adhesion, dimensional stability, hardness, and low shrinkage with cure. The fibers are surface treated and a sizing material is applied as a primer to promote gced adhesion between the graphite and the epoxy.

A typical continuous FRP composite is shown in Figure 2 as an exploded view of layers called laminae. The fibers are commercially available in either unidirectional form, as a tape, or bi-directional as a woven fabric. Continuous fibers in woven fabric have two directional terms. Warp is the direction down the roll of fabric, and fill is the direction across the width. These directions are important in designing the load carrying capability of the finished composite material. Weavers can vary the tow size, number of tows per meter, and even the continuous reiniorcement in either direction, to create unbalanced fabrics. Unidirectional tape and woven fabric are commercially available impregnated with a 
partially cured polymer matrix in a form called a prepreg. The prepreg is ready for cutting and forming into a laminated composite.
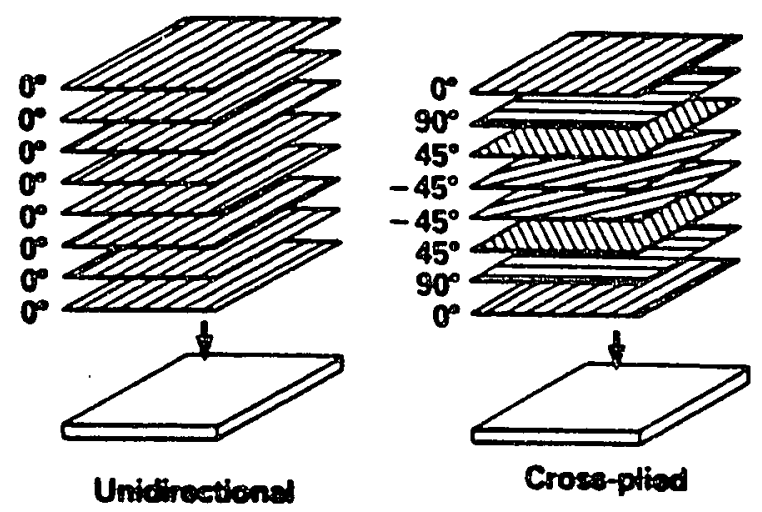

Figure 2. Exploded View of an FRP Laminate.(2)

During manufacturing the laminae are pressed together under elevated temperature and pressure to cure the matrix. The epoxy reacts and flows to bond the laminae together, resulting in a single structure. The cured epoxy provides cohesiveness, transfers load from fiber to fiber, and fixes the geometry of the part. Usually the optimum ratio of fibers to matrix, called the fiber volume, is $60 \%$. Another important advantage of composites in design also is illustrated in Figure 2, in that each lamina can be oriented to maximize the load carrying capability of the resulting manufactured 
part. This allows the part to be specifically tailored to meet the requirements of a design with a minimum of anciliary weight. The laminate must be balanced, or symmetric about the centerline, to prevent thermal warpage after cure, due to the coefficient of thermal expansion mismatch of the composite materials.

\subsection{Toughness in Composites}

Two advantages of FRP composite materials are high strength and high elastic modulus. However, a major obstacle to more widespread application of these materials in structural components is the problem of low toughness of the matrix which promotes delamination (lamina separation). Because of low toughness, composites have been restricted to uses outside of primary load bearing structures where they must withstand impact or cyclic loading close to the yield limit of the material.

Toughness indicates the amount of work expended to fracture the material. However, the term toughness should be regarded as a class of properties rather than a single property. This means that there are several measurable properties related to the amount of work required to produce failure in a material. Usually the most direct way to measure the work of fracture in un-notched specimens is the total area under the stress-strain curve up to the point of 
failure. This gives the energy of fracture per unit volume. Other toughness properties that can be measured are impact-resistance, delamination-resistance, strain-to-failure, and tear-resistance. Another important characteristic of toughness in materials is the ability to withstand limited fracturing without catastrophic failure. This property is called damage tolerance.

The fracture process generally takes place in three stages. First, a crack is initiated, or an initial flaw is present in the material under load. Second, the crack grows in a stable fashion and may link with other cracks. Third, the crack reaches a critical size at the applied stress level, and propagates to failure in an unstable manner. In brittle materials the second stage is repressed, or may be absent. The basis for many techniques to improve toughness is to modify the matrix to absorb a greater amount of strain energy during crack propagation.(3) This can be done by forcing the crack to follow a convoluted path or allowing multiple cracks to be formed. This permits increased deflection of the material with less crack propagation. Another method for increasing the energy absorbed during fracture is for cracks to be arrested at small sites that are able to deform plastically. This lowers the stress present at the crack tip.

Fracture and failure in FRP composites can occur in a number of complex ways because of their laminated construction. Unlike 
homogeneous isotropic materials, fracture can be caused by the failure of individual components, or a separation at the interface between the components. The modes of failure depend on both the direction of the applied load and the orientation of the fibers. Generally, there is not a single, self-propagating crack, as in metals. The typical FRP fracture is characterized by matrix cracking, fiber breakage, and delamination, all of which ultimately combine to produce component failure. Also, internal stresses generally develop when the laminate cools after the matrix has been cured because of differences in the coefficients of thermal expansion. Residual stresses cause unevon fiber loading, causing some fibers or the matrix to fail at low loads. This is evident when test specimens are put under load; it is often reported that prior to failure the specimen will emit acoustic energy characteristic of cracking.

Fractures in FRP can be divided into three basic types: interlaminar, intralaminar, and translaminar.(4) The fracture types are shown in Figure 3, and describe the plane of the fracture with respect to the orientation of the laminae. Translaminar fractures are transverse to the laminated plane, interlaminar fractures are oriented between the laminae, and intralaminar fractures are located internally within a lamina. Translaminar fracture involves significant fiber breakage, while interlaminar and intralaminar fracture occur in the laminate plane, and involve primarily matrix 
fracture. The type of failure reflects the type of load the component was subjected to, such as tension, compression, or shear.
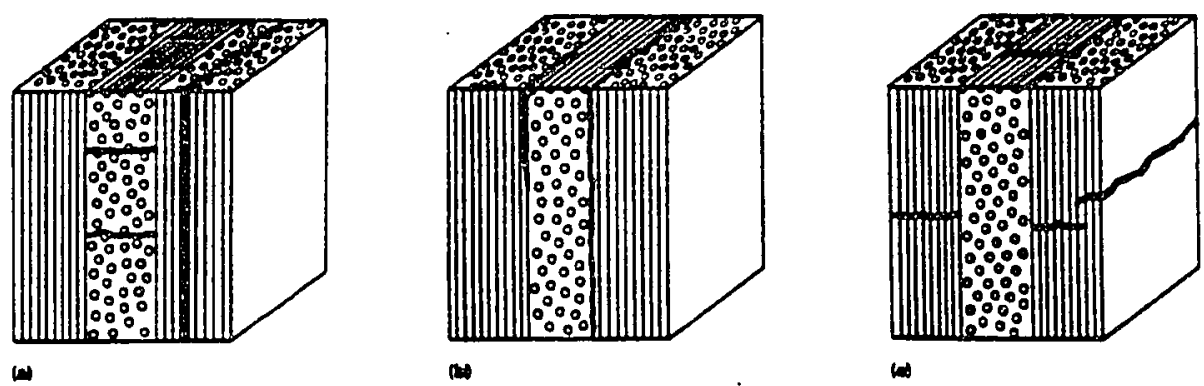

Figure 3: Planes of Separation in Fiber Reinforced Composites: (a) Intralaminar, (b) Interlaminar, (c) Translaminar.(4)

Tensile loading in the fiber direction produces predominantly translaminar fractures with a rough, fiber dominated morphology, and fibers protruding out of the fracture plane. Usually little or no delamination is evident near the fracture surface. Brittle tensile failure of fibers is the primary failure mechanism, and fracture of the surrounding matrix is secondary. Fibers tend to fracture in 
bundles, and the fibers within each bundle have a relatively flat and common fracture phase. Consistent with brittle failures, the fracture origins are primarily located at surface flaws on the fibers.

Both interlaminar and intralaminar fracture occur on a plane parallel to the fiber reinforcement. For the majority of thermosetting matrices in use, such as epoxy, cohesive matrix failure occurs in a brittle manner. Therefore, flexural and shear fracture mechanisms in FRP tend to be dominated by matrix failure and fiber to matrix interface separation. The cohesive fracture characteristically shows a relatively flat fracture plane with very little evidence of material deformation. For this reason, the interlaminar and translaminar failure modes provide excellent opportunities to study toughening mechanisms. A typical method for improving toughness is to improve the matrix ductility which increases resistance to crack propagation. This project examines a proposed toughening mechanism by additives to the epoxy matrix. The toughness is then tested by interiaminar failure in prepared specimens. The objective of the project is to improve FRP toughness without decreasing the strength or the elastic modulus. 


\section{CHAPTER 2 \\ PREVIOUS INVESTIGATIONS IN TOUGHNESS}

\subsection{Reviow of Relevant Investigations}

The approach to improving toughness of composites has been focused on the mechanisms that absorb energy during loading. in general, toughness can be described as the sum of all the contributions to energy dissipation related to fibers, matrix, and the fiber-matrix interface.(5) Some energy dissipation mechanisms related to the matrix and interface are elongation, crazing, crack bridging, matrix-fiber debonding, and friction during fiber slippage. Cairns(6) developed a finite element model to describe the role of individual phases during delamination, and predicted that a more convoluted fracture pattern will require greater energy to fracture. As a result of the convolution, more surface area is created during the fracture. This is shown to be a possibie mechanism for toughening brittle materials.

One method for increasing interlaminar toughness is to introduce tough layers interleaved in the composite matrix. Several methods using this technique were examined by Masters(7), and Sela and Ishai(8). They were able to show increases in impact damage resistance with layers of ductile material interleaved with the 
laminae. They used compressive strength after a standardized impact as the measure of toughness. The effect was that test panels with the tough interlayers had roughly $50 \%$ greater compressive strength after impact than panels without the interleaf. A graph of the results of this investigation is shown in Figure 4. The major disadvantage of this system is a weight penalty. The tough layers add weight without increasing the stiffness and the strength of the laminate.

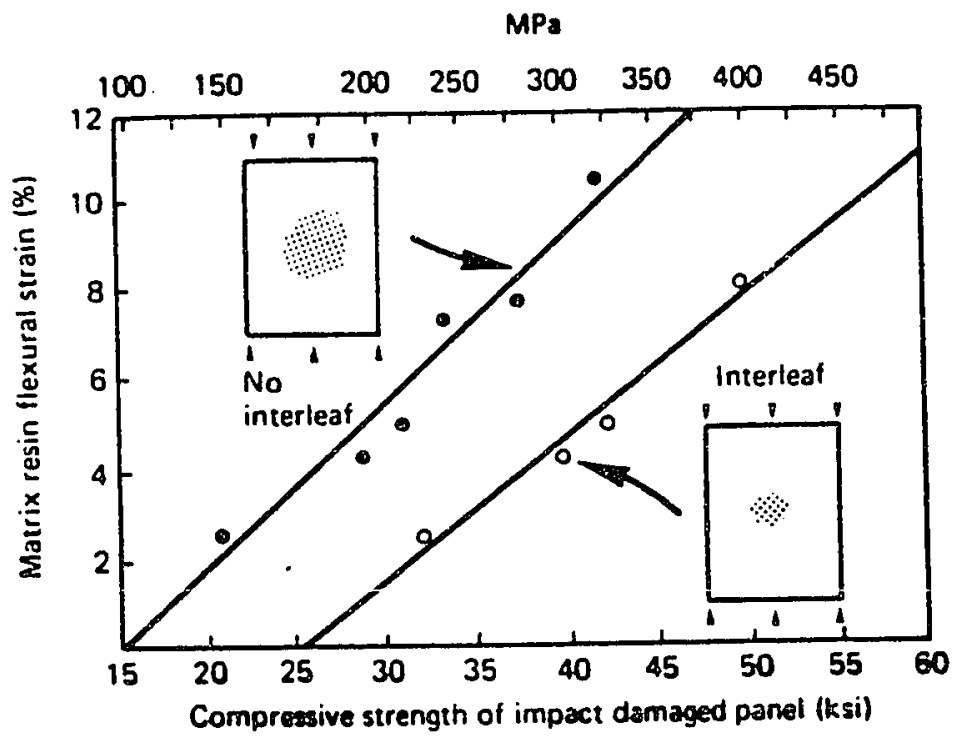

Figure 4. Effect of Interleaving on Impact Damage Resistance.(8)

The value of a low elastic modulus third phase dispersed as particles in the matrix was investigated by Pottick.(9) This investigation used discrete rubber particles widely dispersed in the 
matrix, rather than using tough interlayers. The study showed that the dispersion helped convolute the crack propagation by generating additional plastic deformation at the crack tip. The experimental technique used a moderate amount of rubber which reduced the strength properties. Figure 5 shows the results of adding two blends of rubber up to a weight percent of $15 \%$. The study also showed that an improvement in the toughness was possible with a minor effect to the glass transition temperature. However, this method was accompanied by a $20 \%$ decrease in the flexural modulus.

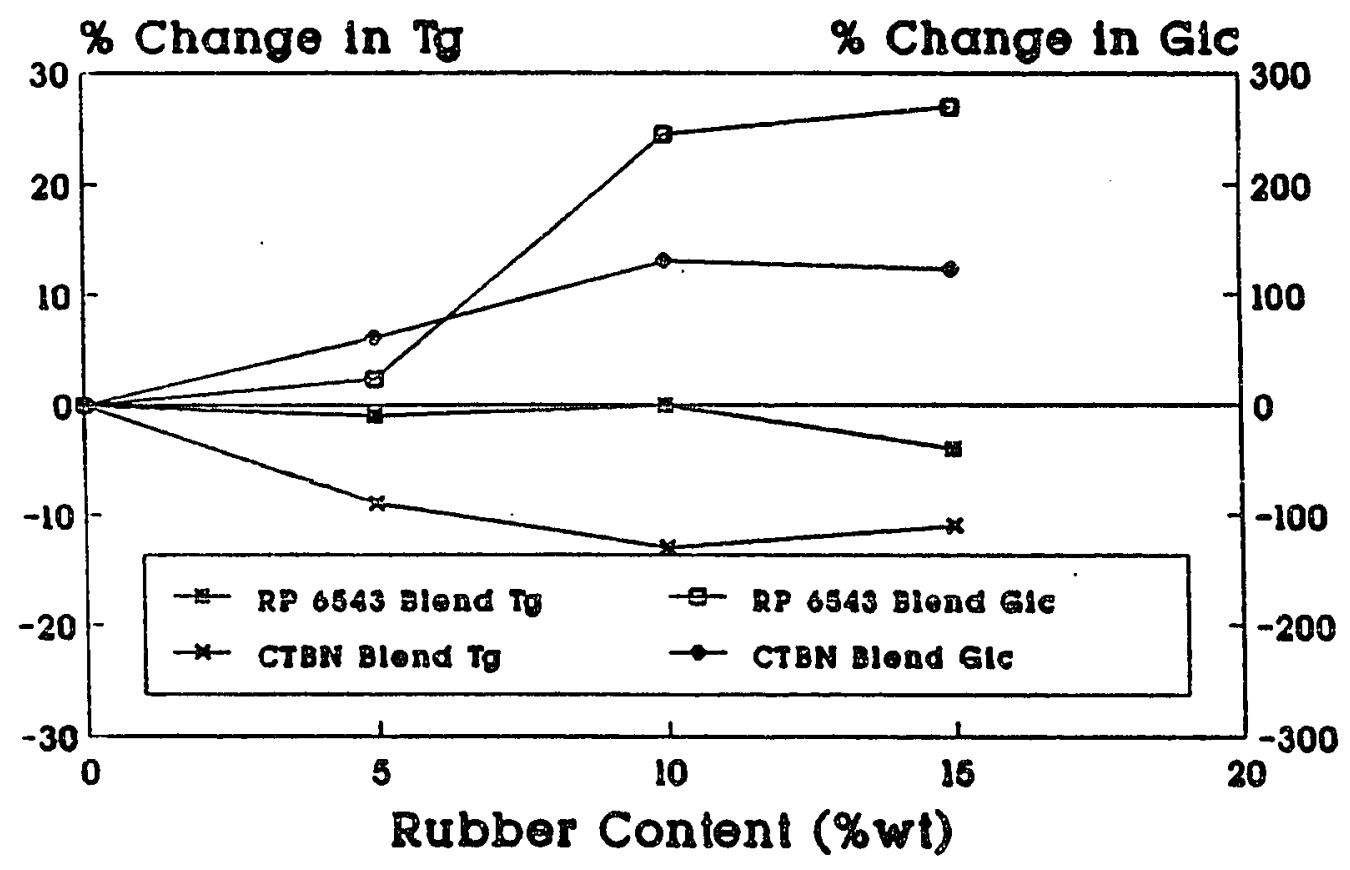

Figure 5. Fracture Energy and $T_{g}$ Changos Versus Rubber Content. (9) 
An extension of the theory of convoluting the growth of cracks was demonstrated by Thorfinnson, et al.(10) Thorfinnson's objective was to improve impact resistance without decreasing the elastic modulus of the composite. The method used glass microfibers added to the epoxy matrix. Instead of using a low elastic modulus filler, such as rubber, the glass microfibers were high modulus, and likely had a strong bond to the epoxy. The importance of this investigation was the size of the microfibers, being less than $70 \mathrm{~nm}$ in diameter, and lengths from 1 to $10 \mu \mathrm{m}$ (aspect ratios of 10 to 100). This particle size was much smaller than that used in previous investigations. The proposed effect of the microfibers was to disrupt crack propagation by creating discontinuities in the matrix. The small size was important in that a very large number of discontinuities can be generated in the matrix with a minimum of added weight or volume. The elastic modulus of the resulting composite material was not decreased because the epoxy content only marginally reduced the cohesiveness and bonding of the fibers. The small size also ensured that the defects formed were smaller than the critical crack size for a given level of stress. Thorfinnson reported that with an $8 \%$ addition of microfibers the FRP toughness, measured in damage tolerance to impact forces, was improved by $15 \%$.

Other investigators have examined the effects at the fibermatrix interface to improve toughness. Saghizadeh and Dharan(11) 
developed a model to estimate the relative contributions from the matrix and the fiber-matrix interface to the overall delamination crack energy. The theoretical crack propagation is illustrated in Figure 6. The study showed that there is a large amount of surface area involved in bonding the fibers, and therefore cracks propagating with both matrix failure and interface failure absorb more energy. This study concluded that increasing the interface energy absorption during crack propagation was more efficient in improving the overall toughness than improving the toughness of the neat* matrix resin alone.

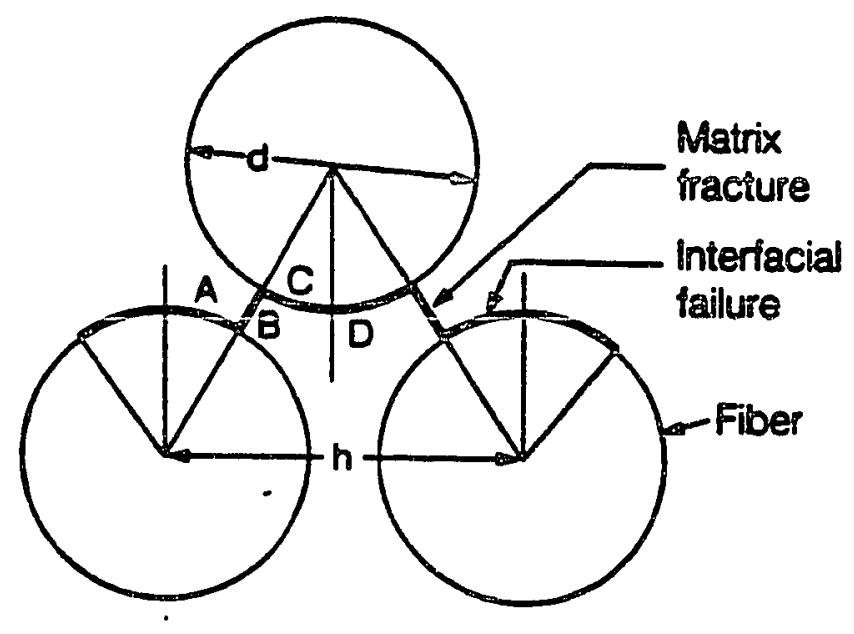

Figure 6. Delamination Model Showing an Assumed Fracture Surface Through a Stylized Hexagonal Array of Fibers.(11)

" "neat" refers to the unfilled, unmodified resin. 
Other studies have shown the fiber-matrix interface to be an important contributor to energy absorbing mechanisms. Piggott and Reboredo(12) showed that the interface often has properties greatly different from both the polymer and the fiber. The interface appears to be very brittle, often markedly more brittle than the polymer, having a work of fracture only about $20 \%$ of the polymer. The investigation showed that if ductility can be increased at the interface, then overall composite toughness should be improved. This supports the conclusions of Saghizadeh and Dharan. Piggott and Reboredo also showed that important friction interactions can take place on the fiber after failure of the interface bond. This is because pressure exists due to the cure shrinkage of the polymer, and that slippage of the fiber after debonding is resisted. The study used single fiber pull-out tests, and showed that due to the large number of fibers, a significant increase to the energy absorbed can be associated with slippage. Figure 7 shows results describing the energy involved in fiber slippage. The study also concluded that fiber interface failure does not necessarily lead to composite failure. A failure in the interface can still transmit stresses by friction. Interfacial pressures may be small, but are significant when coupled with high friction coefficients, giving substantial shear stresses to the fiber. The study reported that increases in the energy absorbed during fraciure is provided by allowing the fibers to slip. 


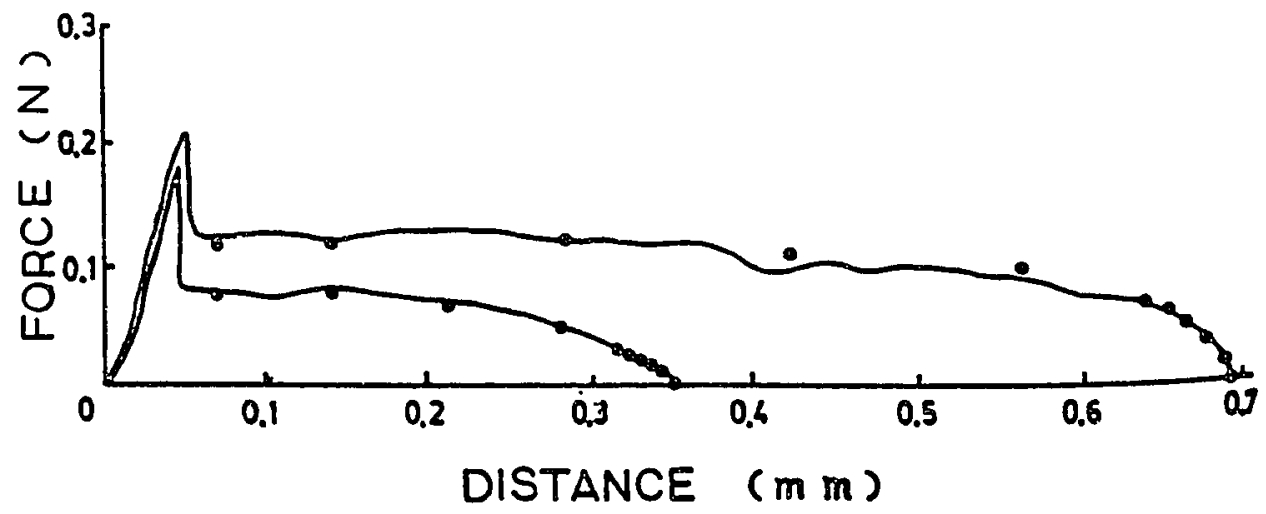

Figure 7. Pull-out Curve For Kevlar Treated with Acetone.(11)

A study by Friedrich(13) into the mechanisms of fracture at the interface includes the effects of a cohesive failure as well as adhesive failure*. The study concluded that a greater amount of energy was absorbed for fiber pull-out having cohesive failure. Frictional forces then are greater because they are generated by both overcoming the adhesive bond between the matrix and fiber, and the physical interlocking and subsequent plastic deformation of pull-out. Interlocking is missing in a pure adhesive failure, and so only frictional forces absorb energy during strain. A schematic of

"A "cohesive failure" refers to a rupture of an adhesive bond, such that the separation appears to be within the bulk adhesive. An "adhesive failure" refers to a rupture at the adhesive-adherend interface. 
this action is shown in Figure 8 as a crack tip extends through fibers producing zones of yielded matrix.

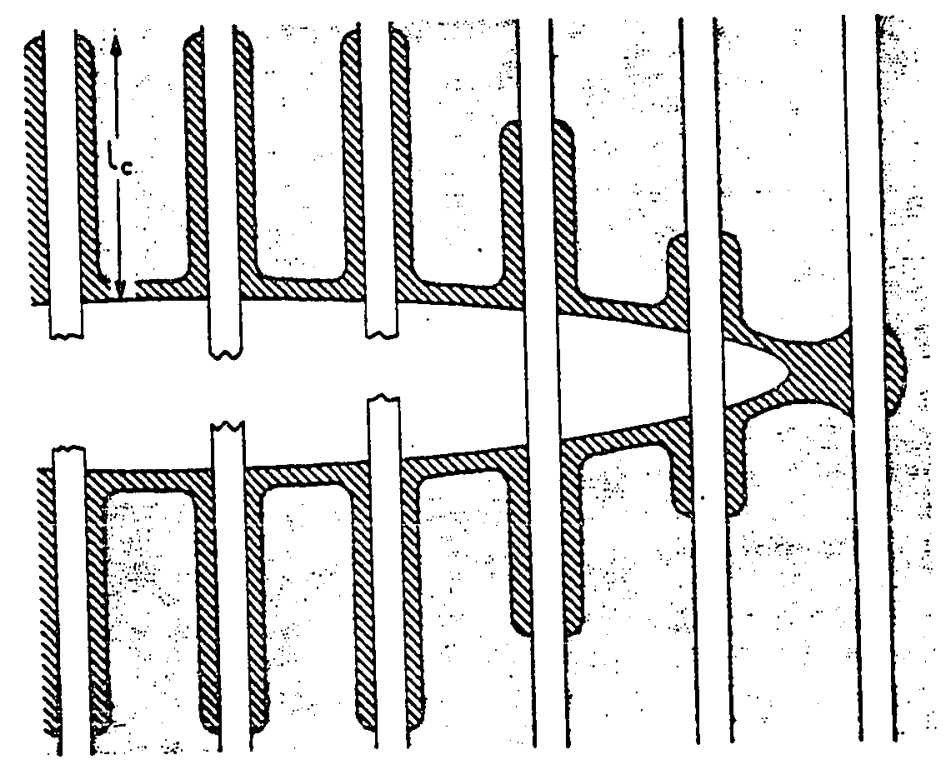

Figure 8. Continuous Fibers Which Fail in the Crack Plane. The Interface is Loaded in Shear and Yields in the Region Close to the Crack.(13) 


\subsection{Summary of Provious Investigations}

Investigators in the field of improving toughness in FRP materials have used various techniques to increase energy absorbing mechanisms. One of the successful methods is the application of a second phase of more ductile material added to the matrix to retard crack propagation. Other methods have included the use of small defects in the matrix designed to disrupt crack propagation. This results in an increase in the surface area of the fracture. Still other methods have examined the effects of improving the ductility at the fiber-matrix interface. This project uses these previous investigations to develop a method of improving toughness by adding a second phase of ductile plastic to the matrix. The second phase is in the form of small discrete particles that would retard crack propagation by being ductile, and increase the surface area generated by being numerous. 


\section{CHAPTER 3}

\section{EXPERIMENTAL OBJECTIVES}

Improvements in the toughness of FRP composites can be achieved by introducing additional mechanisms that absorb energy during crack formation and propagation under an applied load. Some investigations, as described in Chapter 2, examined methods to improve toughness by adding a second, more ductile, phase to the matrix. Other studies showed it was possible to improve toughness by introducing small defects below the critical crack size. This causes propagating cracks to follow a more convoluted path, and thus generate more surface area.

This project uses the previous research, and proposes that if numerous, well distributed, and very small defects are introduced into the composite matrix an improvement to toughness will be achieved. Defects can be added to the matrix in the form of small particles of a ductile material. As the total weight percent of the added defects remains low, improvements to toughness are not expected to be accompanied by decreases to the composite strength and elastic modulus.

The increase in toughness can be realized because cracks will initiate at many small sites, consuming part of the energy that 
otherwise would be available for propagation of a main crack. Cracks that form can remain small, below the critical crack size, for a given amount of strain because there are more of them. Also, if the added defects are in the form of a ductile third phase material, a propagating crack will tend to form a convoluted path as the crack tip reaches sites that will plastically deform. The convoluted path increases the absorbed energy by increasing the amount of surface area generated.

An experiment supporting this thesis was conducted to test the effectiveness of small, 0.1 to $5 \mu \mathrm{m}$, Teflon $\Theta$ particles dispersed in the matrix to improve the toughness in a graphite fiber reinforced plastic (GFRP). The objective was to disperse the small particles uniformly in the matrix, generating numerous sites of a third phase low elastic modulus material. The experiment used Tefion particles because of the excellent ductility of Tefton, the small particle size, and because the low bonding properties of Tefion ensured the formation of defects in the matrix. This allows the Tefion particles to retard the propagation of cracks by being ductile, and also to convolute the crack path and generate more surface area by being very numerous. The particle size distribution for the Tefion powder was such that for a $1 \%$ addition to the prepreg, approximately $4 \times$ $10^{8}$ particles per $\mathrm{cm}^{3}$ were introduced into the resin. Since the volume percent of added material was small, the surface area of debonded fiber was expected to be negligible, leaving the fiber 
dominated properties of strength and elastic modulus relatively unaffecied.

In this project Teflon powder was added to the prepreg laminae before lay-up in the amounts of $0,1,2,4$, and $6 \%$ by weight. The $0 \%$ test panels were used as the control sample for comparison. A more complete description of the calculations and the methods of measuring the foughness is given in Section 4.8. 
CHAPTER 4

EXPERIMENTAL DETAILS

This project extends the investigation reported by Thorfinnson(10) by making some important changes. In Thorfinnson's study, very small particles of glass fibers, less than $70 \mathrm{~nm}$ in diameter, were used to introduce defects into the matrix. The defects were generated by a high elastic modulus material, and were applied by blending directly into the liquid epoxy prior to impregnating the graphite fibers. In this project the defects were added to the matrix using a thermoplastic polymer of low elastic modulus in the form of very fine Tefion powder. The powder was applied directly to each lamina before lay-up and cure of the panels. The particle size of the Tefion powder was typically $3 \mu \mathrm{m}$, and the particle shape was roughly spherical. Although the previous study was able to introduce a greater number of defects per weight percent of added material, the use of a low elastic modulus particle, instead of high modulus glass, was expected to have the effect of allowing greater matrix deformation to occur in the region of high stress surrounding each particle. In Thorfinnson's study the glass fibers likely had a strong bond to the epoxy when forming the defects, whereas the Tefion particles in this project did not bond to the epoxy. This was expected to have the effect of generating a large number of very small cracks under the critical crack size. 
The experimental work for this project was performed in the following sequence:

1. Acquire raw materials;

2. Cut prepreg into panel size for lay up;

3. Weigh each ply, and add Tefion powder;

4. Lay up lamina into panels;

5. Assemble and bag panels for cure;

6. Autoclave cure panels;

7. Cut panels into 3 point bend specimens, identify warp and fill directions;

8. Mechanical test each specimen in flexure;

9. Reduce and analyze data, and report results.

Significant items for these steps are described below.

\subsection{Raw Materials}

The choice of a graphite epoxy composite for this study was made because of the wide industrial use of such materials. Graphite fiber reinforced plastics (GFRP) are also widely known for relatively low toughness properties, and as such provide excellent sensitivity for measuring small changes. A woven fabric of graphite fibers was cesirable both because of its common usage, and the ability to test toughness changes in warp and fill directions. The GFRP used in this 
project was a commercially available product from Fiberite Corporation, HMF 2409/34. This system has T300 graphite fibers pre-impregnated with Fiberite 934 resin. The weave pattern is $5 \mathrm{HS}$ Satin, with 1000 fibers per tow, and balanced in the warp and fill directions. The fabric weave pattern is shown in Figure 9.

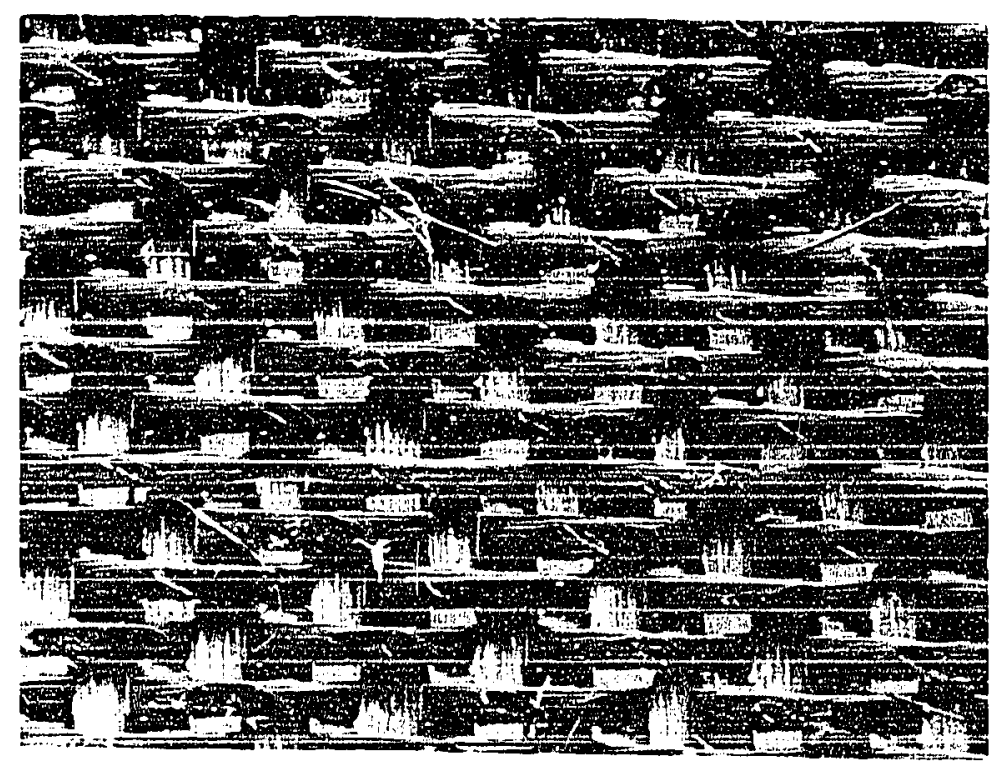

Figure 9. HMF 2409/34 Prepreg, with 5HS Satin Weave Pattern (5X). Warp direction is across the width of the page. The warp face is shown up. 
The Tefion powder used in this project was selected for its small particle size, and because it was available as a dry product ready to add to the prepreg without chemically affecting the epoxy resin. A commercially available product, MP1100, with particle size distribution in the range of $0.1 \mu \mathrm{m}$ to $5 \mu \mathrm{m}$, was obtained from E.I. duPont de Nemours and Company, Inc.

\subsection{Material Preparation}

The prepreg was obtained in rolls from a single lot number which assured consistency of properties. The prepreg was cut into plies of $24 \mathrm{~cm}$ by $30.6 \mathrm{~cm}$ to prepare for lay up. To add the Tefion powder in the desired amounts, each ply was first weighed, then the powder was brush applied to the prepreg surface by hand. A quantity of powder was added and the ply weighed again to verify the weight gain. Powder was added in small quantities until a target value was reached. A ply typically weighed 17 grams, so for a $1 \%$ sample 0.17 grams of powder would be added. It was desirable to add the powder in several light coats to reach the target value more accurately, and to cover the surface more uniformly. The uniformity of the powder was able to be checked visually because of the contrast from the white powder against the black prepreg. On a macroscopic scale the uniformity of the powder appeared quite good. A magnified view of

the surface of the prepreg before the application of Tefion is shown 
in Figure 10. Views showing prepreg surfaces after the application of powder are illustrated in Figures 11, 12, 13, and 14, for 1\%, 2\%, $4 \%$, and $6 \%$ Teflon, respectively. The Teflon becomes progressively more dominant on the surfaces as white deposits filling in depressions, and accumulating against the fiber tows in the weave pattern. The Teflon distribution on a large scale appeared generally uniform, but on the scale of the size of the weave pattern the distribution was not uniform because of the roughness of the surface.

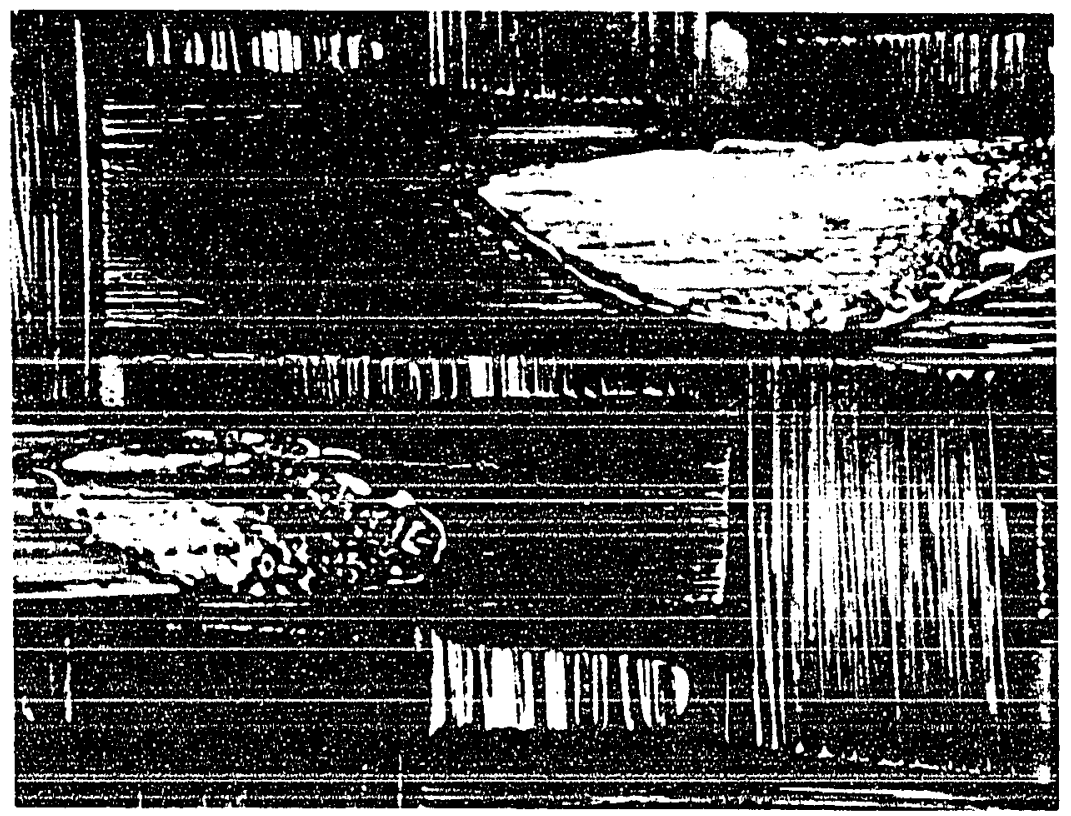

Figure 10. Prepreg Surface Before Application of Teflon Powder(32X). 


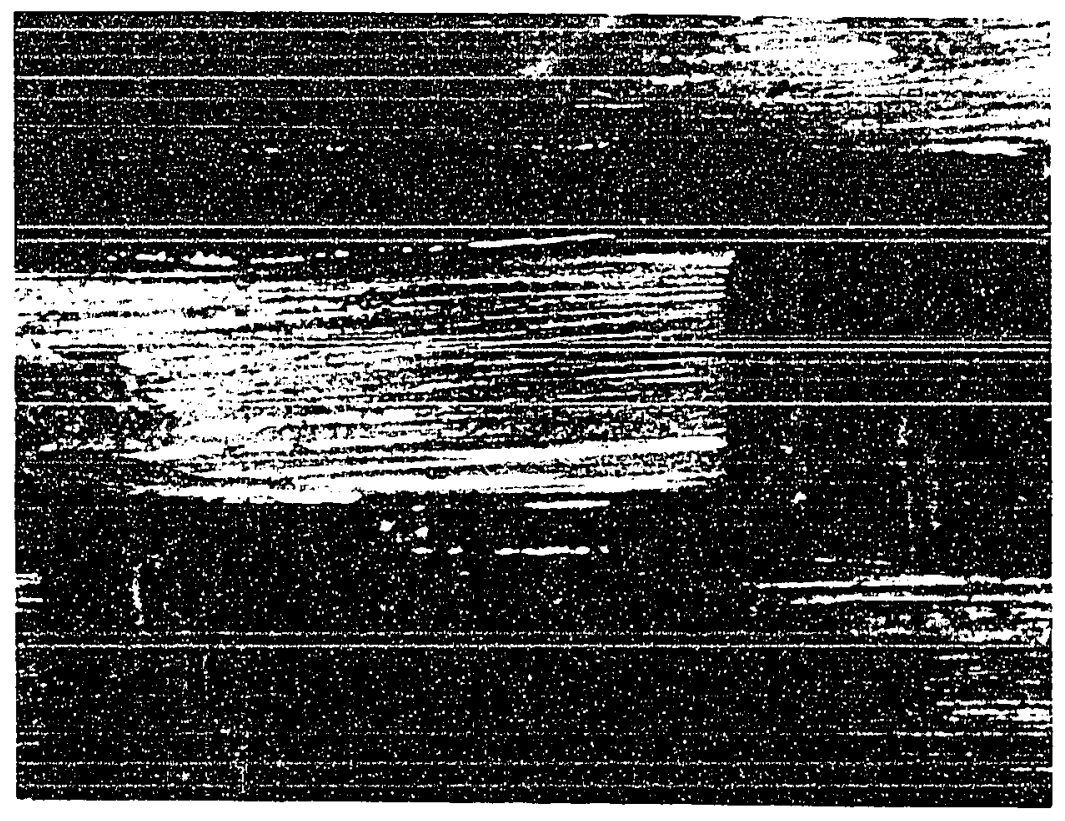

Figure 11. Prepreg Surface After Application of $1 \%$ Teflon Powder (32X).

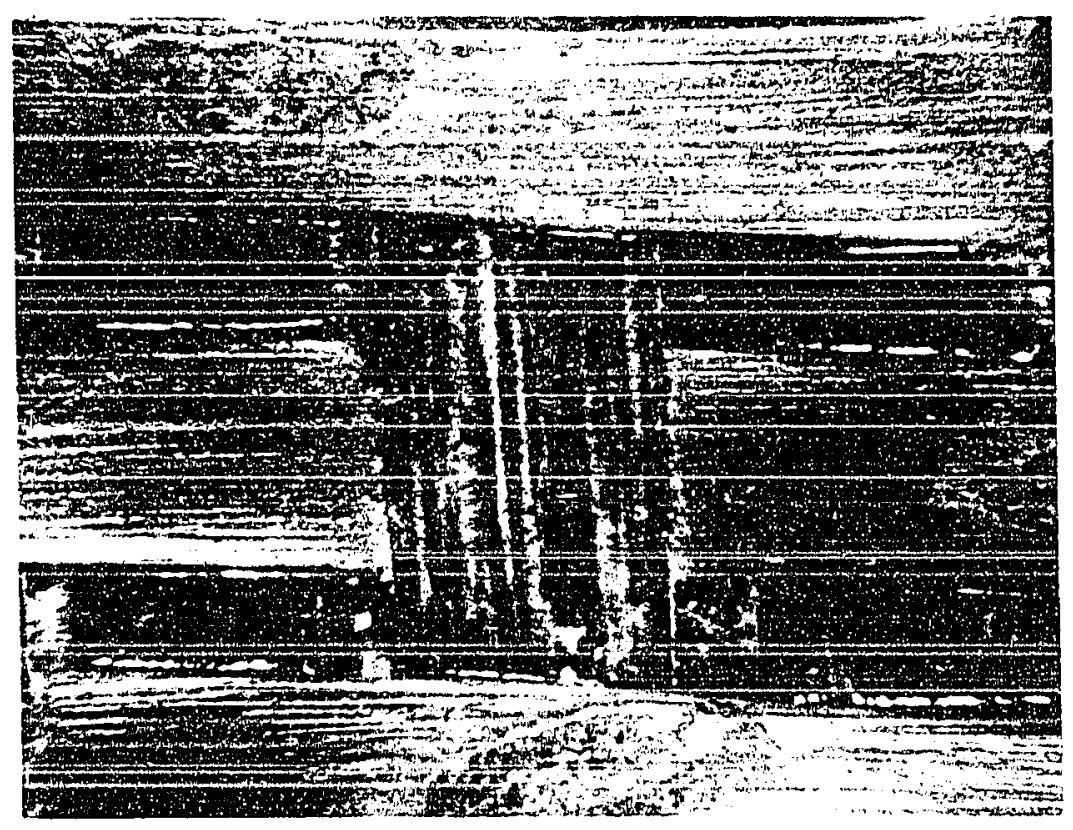

Figure 12. Prepreg Surface After Application of $2 \%$ Teflon Powder (32X). 


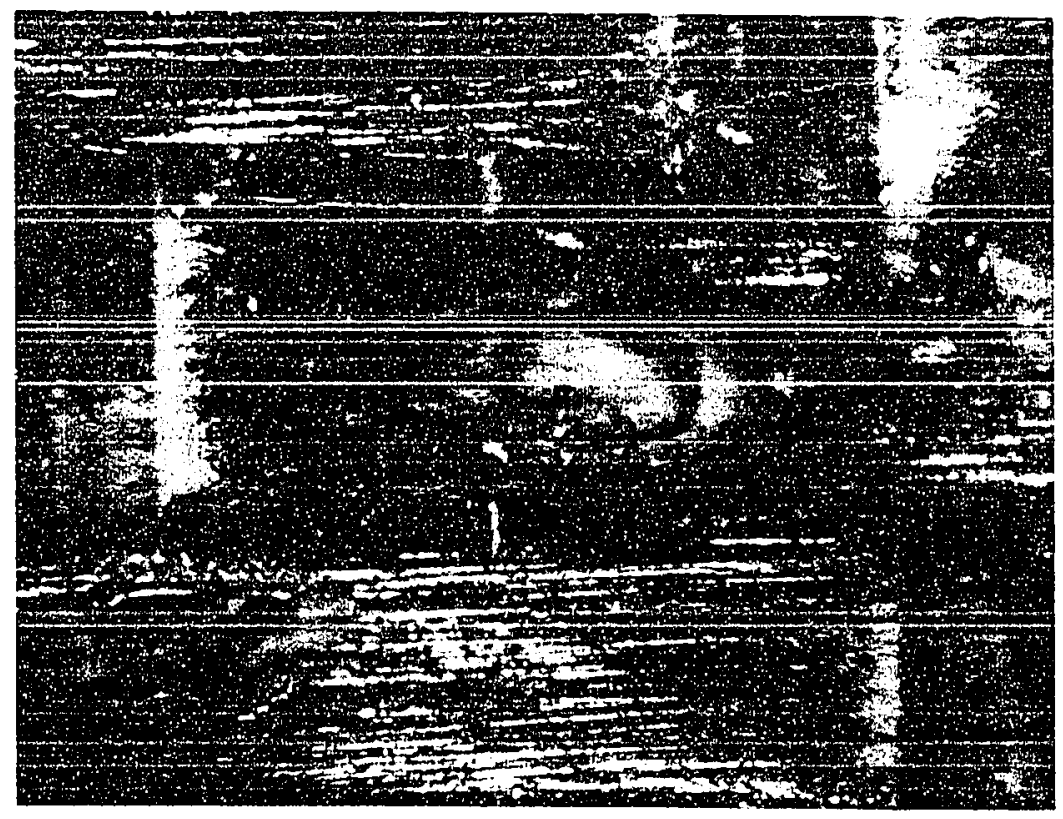

Figure 13. Prepreg Surface After Application of 4\% Teflon Powder (32X).

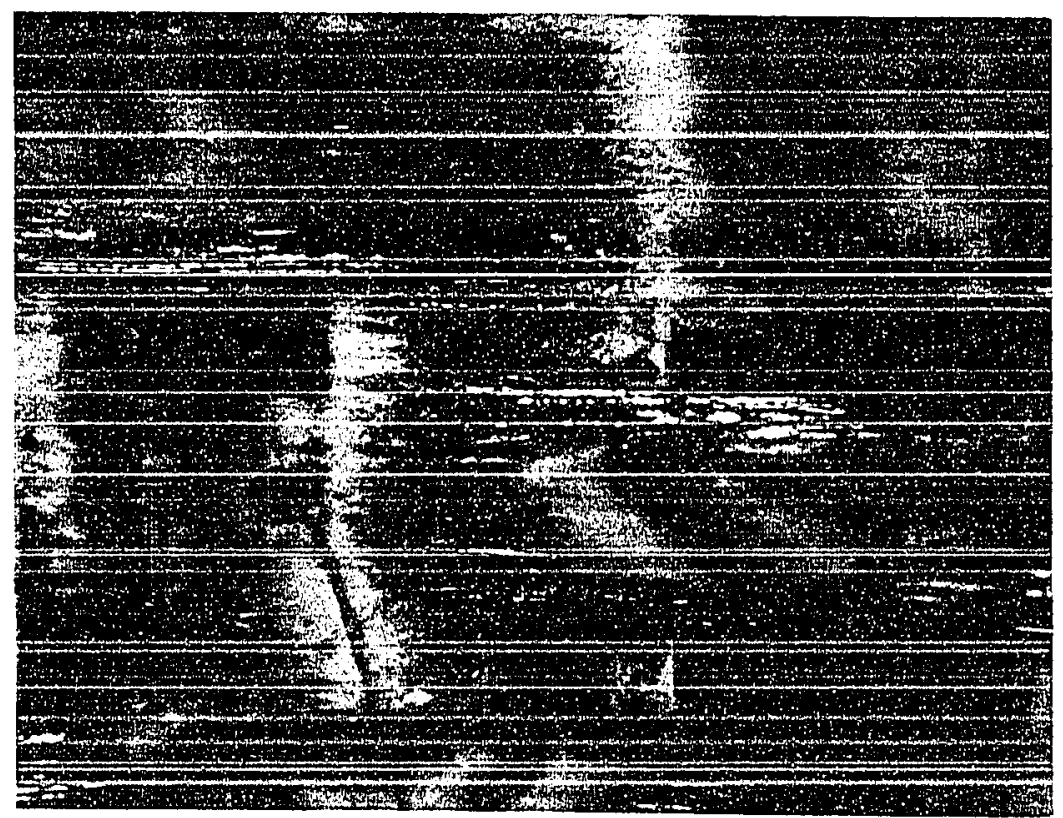

Figure 14. Prepreg Surface After Application of $6 \%$ Tefion Powder (32X). 
After each ply was prepared with Teflon powder, the panels were stacked up for curing with 16 plies per panel to produce a target thickness of $0.25 \mathrm{~cm}$. All panels were fabricated exactly the same with the Teflon added to the side opposite the peel ply, and then stacked with the peel ply side up for autoclave curing. Later, when the panels were cut into specimens and tested, the same orientation was always maintained for each panel with the peel ply side down (warp face up). A total of 16 panels were produced, with 4 panels each at Tefion concentrations of $0 \%, 2 \%$, and $4 \%$, three panels at $1 \%$, and one panel at $6 \%$. The panels were identified by assigning a letter to each panel in the order fabricated. All pertinent fabrication data was kept with the assigned identification letter. Since the weight gained by adding Teflon was not precise the actual concentration varied slightly from the target value. The Teflon concentrations are given in Table 1 . Panels $I, J, K$, and $L$ were not used because a leak developed in the vacuum bagging during the autoclave cure and complete compression of the laminate did not take place. During cure some resin would flow, bleeding out of the panel, and carrying with it a small amount of Tefion. The amount of resin lost was measured by weighing the panels before and after cure. The average value of lost resin was $0.75 \mathrm{~g}$, and for a $4 \%$ panel that would carry with it approximately $0.09 \mathrm{~g}$ of Teflon (assuming a uniform distribution of Tefion in the resin). Since a typical panel 
weighed $300 \mathrm{~g}$, the $4 \%$ added Tefion weighed $12 \mathrm{~g}$. This meant that the loss of Tefion by resin bleed-out was negligible, and did not need to be accounted for.

Table 1. Teflon Concentrations added to Each Panel.

\begin{tabular}{|c|c|c|c|}
\hline ID & Tefion (\%) & ID & Teflon (\%) \\
\hline A & 0 & $M$ & 0 \\
\hline B & 1.99 & $N$ & 1.14 \\
\hline C & 1.16 & 0 & 2.02 \\
\hline D & 4.25 & $\mathbf{P}$ & 4.04 \\
\hline$E$ & 0 & $\mathbf{Q}$ & 6.16 \\
\hline$F$ & 1.28 & $\mathbf{R}$ & 0 \\
\hline $\mathbf{G}$ & 2.17 & $S$ & 2.18 \\
\hline$H$ & 4.13 & $T$ & 4.08 \\
\hline
\end{tabular}

\subsection{Cure Cycle}

The panels were bagged for autoclave cure. The vacuum bagging assembly is shown schematically in Figure 15. 


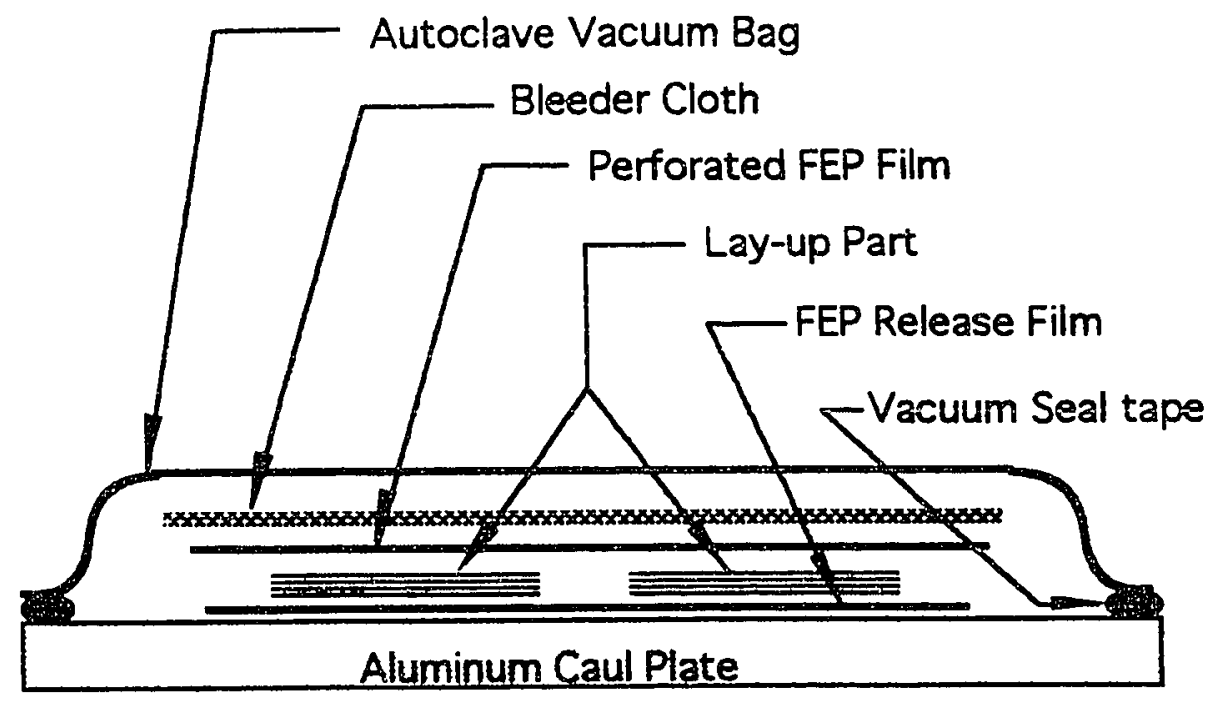

Figure 15. GFRP Lay Up Prepared for Autoclave Cure.

Four panels were cured together in each autoclave cycle. The arrangement of panels on the caul plate for the autoclave is shown in Figure 16. To produce 16 panels, four separate autoclave cycles were run. The temperature, pressure, and vacuum for each cycle were controlled by a microprocessor. The settings were the same for each cycle. The autoclave and control system tolerance on the temperature and pressure is $\pm 6^{\circ} \mathrm{C}$, and $\pm 70 \mathrm{KPa}$. 


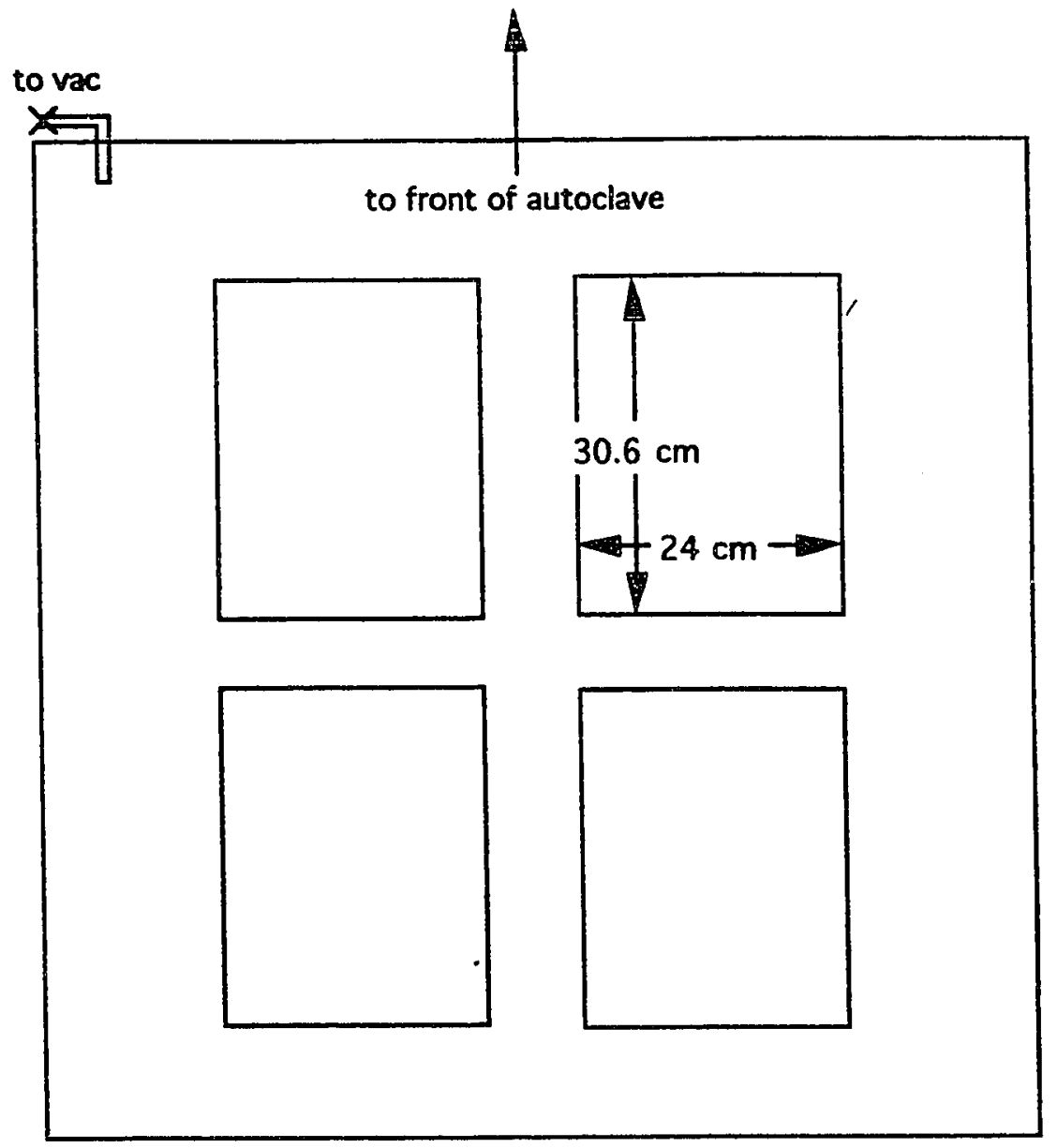

Figure 16. Four Panel Arrangement on Autoclave Caul Plate.

The cure is typical for a Fiberite 934 resin system and has several important sieps, as shown in Figure 17. The resin is cured at $182^{\circ} \mathrm{C}$ for two hours under $690 \mathrm{KPa}$ pressure. The autoclave first stages the parts at $121^{\circ} \mathrm{C}$ for 55 minuies to start the cure of the resin. This increases the viscosity of the resin, and thus prevents excessive flow at elevated temperatures, before the epoxy has a 
chance to fully cure. At 15 minutes into the $121^{\circ} \mathrm{C}$ stage the autoclave pressure is increased to $690 \mathrm{KPa}$ to compact the laminate. At this stage excess resin bleeds out of the panels, through the perforated FEP film, and is absorbed by the bleeder cloth as shown on Figure 15. The process is designed to provide low flow of the resin to achieve a fiber volume of $60 \%$. A vacuum of approximately $100 \mathrm{KPa}$ below ambient is applied on the parts throughout the duration of the cure cycle. This removes trapped gases, moisture, and residue solvents from the prepreg as it cures.

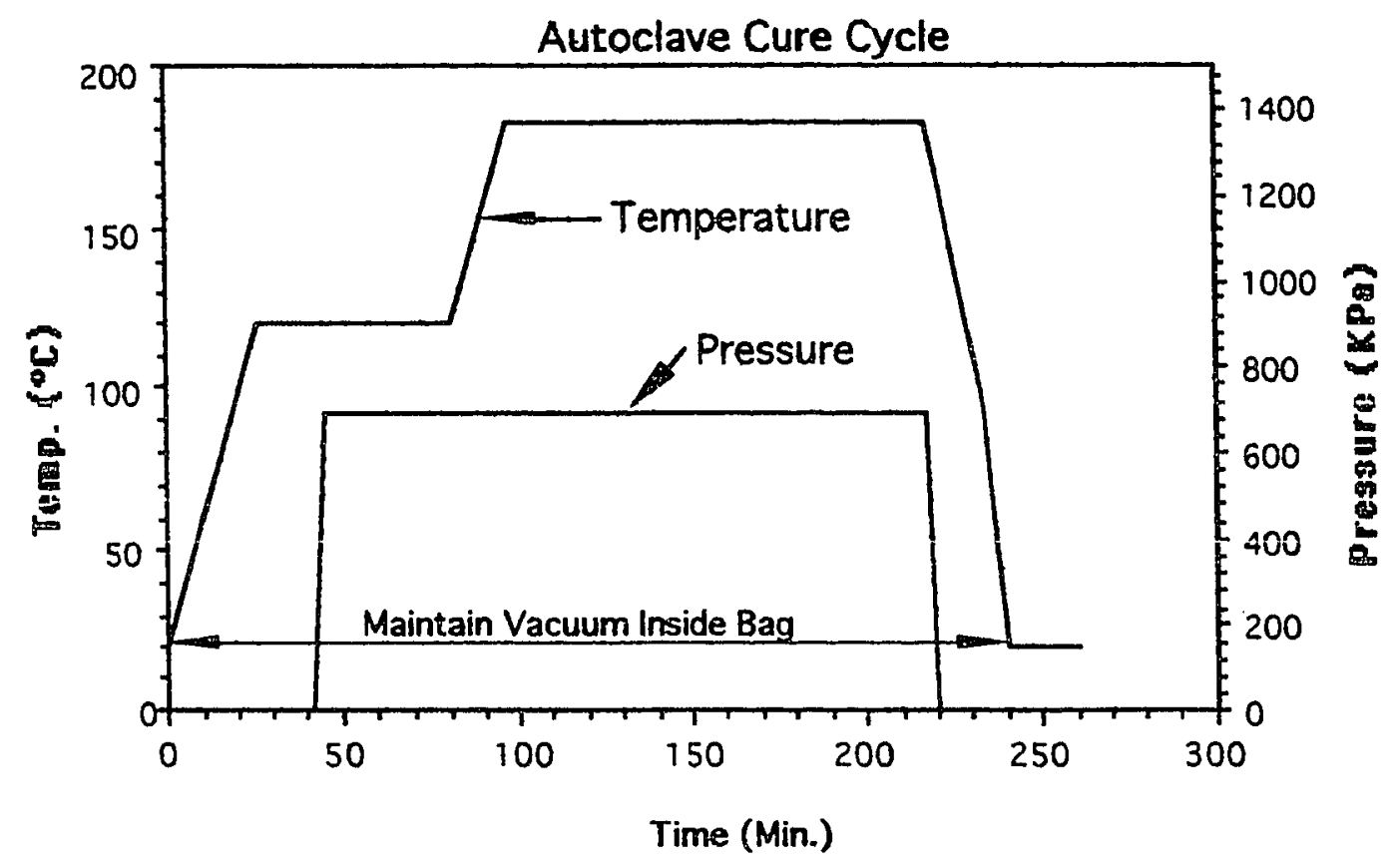

Figure 17. Autoclave Cure Cycle. 


\subsection{Specimen Preparation}

After cure the panels were trimmed to $21.6 \mathrm{~cm}$ by $28 \mathrm{~cm}$ and cut into five blanks labeled $A$ through $E$, as shown in Figure 18. All cutting was done with a diamond saw to produce clean edges, and smooth surfaces. Twenty 3 point bend specimens were then cut from each panel, with 10 specimens in the warp direction from blank $A$, and 10 specimens in the fill direction form blanks $C$ and $D$. The size of the specimen, and the configuration of the test is per ASTM D 790(14). The dimensions of the specimen are illustrated in Figure 19. This provides a span to thickness ratio of approximately 25. Each 3 point bend specimen was identified with two letters specifying the panel and blank, then numbered sequentially in the order cut. 


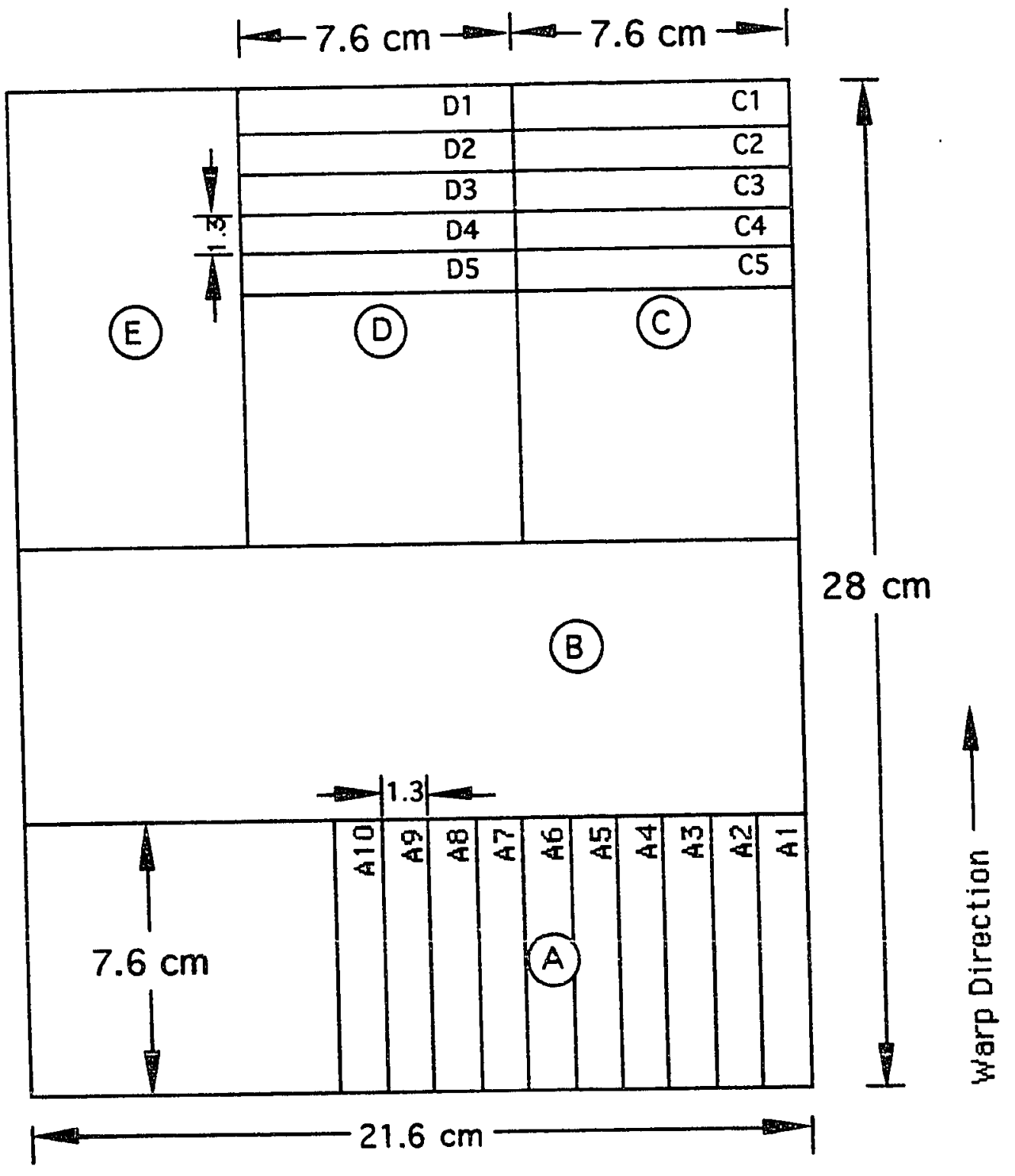

Fill Direction

Figure 18. Panel Cutting Diagram. 

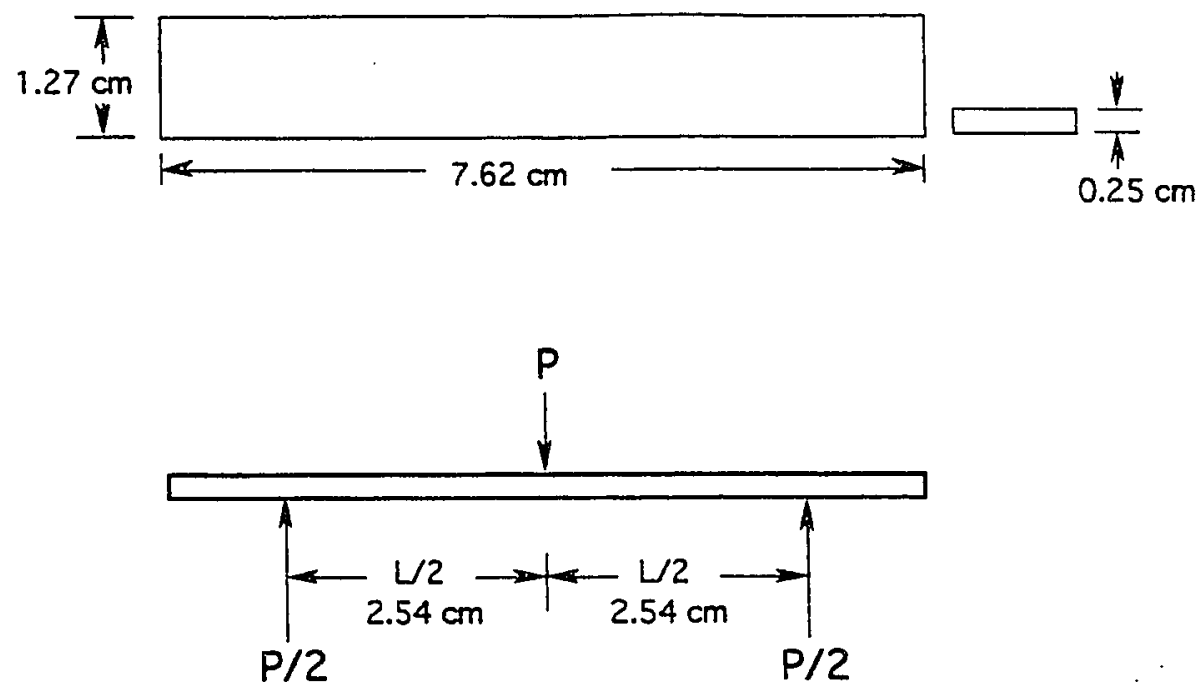

Figure 19. Three Point Bend Test Specimen.

\subsection{Three Point Bend Test}

The three point bend test is an accurate method for determining the flexural properties on flat specimens of GFRP. The test is standardized in ASTM D 790. The specimens are relatively easy to fabricate, and the test is readily performed on an instrumented mechanical tester configured in flexural compression mode. A disadvantage of this type of test is that the volume of the specimen under load is small. This means that if the samples are not uniform in properties there may be a large amount of scatter in the data as defects (voids, inclusions, broken fibers, and 
misalignment of laminae) have random probabilities of being included in the volume under load.

The three point bend test has several advantages when being used to test for toughness. The test produces a well defined loaddeflection curve, and has well defined points for measuring specimen yield and break. The amount of strain after yield is readily calculated from this data. Since the three point bend test generates shear forces in the specimen, the failure mode is primarily by delamination, fiber fracture, and pull-out. This is the same mode of failure generated by impact tests on GFRP. However, because it is capable of producing a well defined stress-strain curve, the three point bend test can produce toughness data in a more quantitative and repeatable basis than Charpy or Izod impact tests.(15) Results from the three point bend test do not directly correlate to the impact type tests because of differences in the test parameters, such as crosshead speed.

\subsection{Experimental Test Variables}

This experiment was designed to test the relationship between the amount of Teiton powder added to the GFRP and the toughness of the resulting samples. All other variables in the fabrication process were held constant, except the amount of Tefion added. All sample 
panels were made from the same manufacturing lot number of prepreg. All panels were prepared, cured, and cut into specimens using the same process. As mentioned in Section 4.2, Tefion was always added to the side opposite the peel ply, and the same orientation for all panels was maintained throughout the experiment. The Tefion was added to the test panels in concentrations ranging from $0 \%$ to $6 \%$. The $0 \%$ test panels became the control samples.

Three point bend tests were performed on the test specimens in the warp and fill directions to test the effectiveness of the Tefion in both directions.

\subsection{Data Acquisition System}

The three point bend test was set up on an Instron Series IX, Model 4505. The Instron system has a computer control for setting the test parameters, and recording data.

Each specimen was loaded to failure, and the data recorded and stored on magnetic disk. The crosshead speed was $1.27 \mathrm{~mm} /$ minute. The Instron was programmed to measure and record load and displacement at a rate of 10 data points per second. The measurement accuracy of the Instron system is $\pm 0.013 \mathrm{~mm}$ in displacement, and \pm 4 Newrons in load. The system was programmed to calculated stress and strain at each data point using the input 
parameters of specimen gauge length, width, and thickness. The calculated stress is the maximum stress in the outer fibers occurring at midspan. Likewise, the strain is the maximum strain in the outer fibers occurring at midspan. The flexural modulus is the stress divided by strain calculated from the maximum slope in the elastic region before yield.

Stress, in $\mathrm{MPa}$, for a 3 point bend sample was calculated by the formula:

$$
\sigma=\frac{3 \cdot P \cdot L}{2 \cdot w \cdot t^{2}}
$$

$$
\text { with } \quad \begin{aligned}
& P=\text { load }(N) \\
& L=\text { gauge length }(\mathrm{mm}) \\
& W=\text { specimen width }(\mathrm{mm}) \\
& t=\text { specimen thickness }(\mathrm{mm}) .
\end{aligned}
$$

Strain, in $\mathrm{mm} / \mathrm{mm}$, was calculated by the formula:

$$
\varepsilon=\frac{6 \cdot \mathrm{D} \cdot \mathrm{t}}{\mathrm{L}^{2}}
$$

with $\quad D=$ displacement $(\mathrm{mm})$. 
The flexural modulus, in MPa, was calculated by the formula:

$$
E=\frac{P}{D} \cdot \frac{L^{3}}{4 \cdot W \cdot t^{3}}
$$

These formulas calculate an apparent flexural modulus that is approximately $12 \%$ lower than the tensile elastic modulus for this size specimen with a span to thickness ratio of 25.(16) The primary method of evaluating of the data was by comparing the test samples with the control samples. Since all data were calculated using the same formula, this approximation did not affect the results.

The instrumented mechanical test machine was programmed to measure and record the maximum stress, strain, and flexural modulus for the linear elastic region of the stress-strain curve. The Instron detected the yield point by the offset method, as shown in Figure 20. The offset is a user-defined value, and was selected for this test after a set of trial specimens were run to determine the shape of the stress-strain curve. 


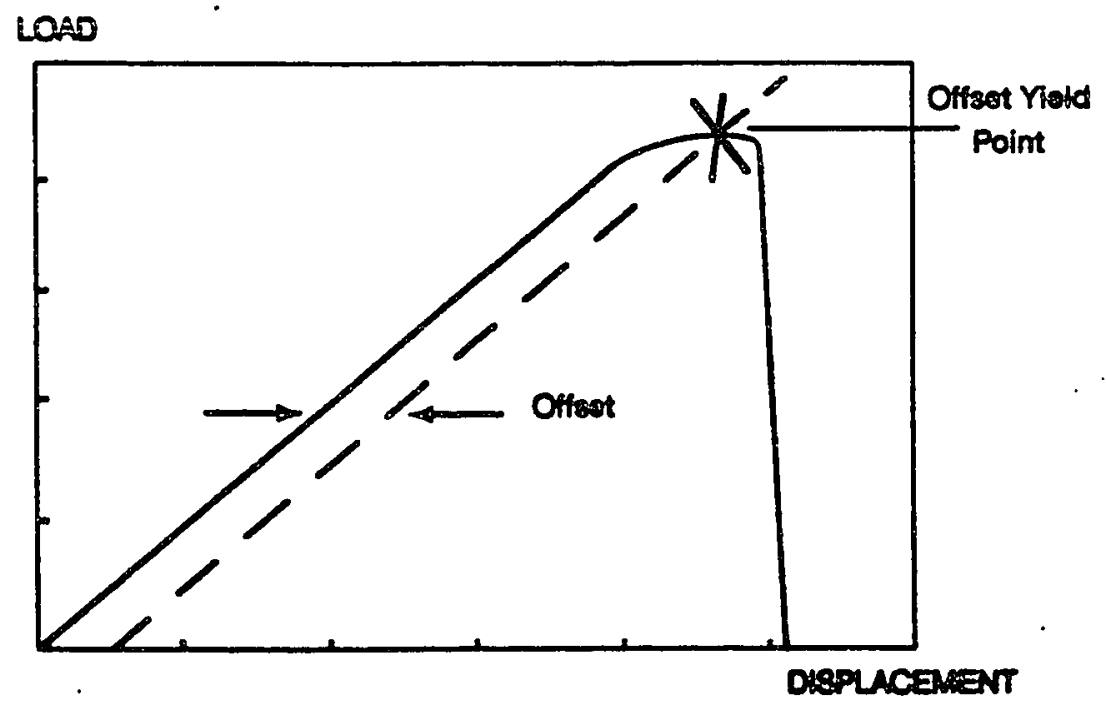

Figure 20 Offset Yield Method

The offset value used was $0.02 \mathrm{~mm}$ of displacement from the slope, which is roughiy equivaient to $0.01 \%$ strain. The value represented a compromise between a lower value, which could prematurely detect yield when small deviations occur while the test is still in the linear elastic region, and a larger value, which could be delayed in detecting delamination. The small strain value of the offset detect point is characteristic of a brittle material, such as the GFRP. Once the offset value was defined it was held constant throughout the test. 
The instrumented mechanical test machine was also programmed to detect and record stress $\left(\sigma_{b}\right)$ and strain $\left(\varepsilon_{b}\right)$ at the specimen break point. The break point criteria also is a userdeñned value specifying the decrease in load from the maximum load. Again, this value was selected after some trial runs. The value selected was $20 \%$ because in a typical structure a loss of load bearing cápability on that order would be defined as a failure. This value fit well into the data set because for the fully brittle specimens the break point showed loss of load clearly in excess of $20 \%$, and for specimens showing delamination before break the loss of load was less than $20 \%$.

\subsection{Method of Calculating Toughness and Damage Tolerance}

The toughness was measured quantitatively as energy per unit volume by the area under the stress strain curve for a three point bend specimen. This is identified as the total energy of failure:

$$
E_{T}=\int \sigma * d \varepsilon
$$

A measure of the energy of deflection in the linear elastic region of the stress-strain curve is the resilience, and is defined as: 


$$
\text { Resilience }=\frac{\sigma_{y} * \varepsilon_{y}}{2}
$$

Two additional relative measures of damage tolerance were calculated from the three point bend test data: delta-strain from yield to break, and the delta-strain times stress at break. The delta-strain $(\Delta \varepsilon)$ is the strain at the break point $\left(\varepsilon_{b}\right)$ minus the strain at the yield point $\left(\varepsilon_{y}\right)$ :

$$
\Delta \varepsilon=\varepsilon_{\mathrm{b}}-\varepsilon_{\mathrm{y}}
$$

The $\Delta \varepsilon$ times stress at break $\left(\sigma_{b}\right)$ is a measure of the energy absorbed after yielding begins, and is identified as the energy of fracture:

$$
E_{f}=\Delta \varepsilon \cdot \sigma_{b}
$$

All three measures of toughness were used to compare the performance of the test panels against the control panels. The three point bend test was used as a simple and effective mothod to measure delamination toughness of interlaminar and intralaminar fracture. 


\section{CHAPTER 5}

\section{EXPERIMENTAL RESULTS}

Sixteen panels were fabricated with concentrations of Tefion ranging from $0 \%$ to $6 \%$ added to the resin. Three point bend test specimens were cut from each panel, and loaded to failure with the instrumented mechanical test machine and the method described in Section 4.5. Stress and strain measurements were obtained for each specimen. Values for the flexural modulus, fracture energy, and total energy of failure were calculated from the stress and strain data. The data for all specimens are presented in Appendix 1.

In general, all the test specimens behaved in a brittle manner. The elastic portion on the stress-strain curve was relatively straight, and ended with a discontinuous portion in a delamination fracture. There was an increased amount of deflection from the point of initial yielding to the point of failure in specimens with added Teflon. This is measured as increased damage tolerance. However, it is important to recognize that the yielding is not plastic deformation of the GFRP material. The mechanism of yielding is one of progressive delamination, where the material under load fails by partial delamination, while the remaining plies continue to carry the load. This is observed during lesting as the specimen under load will emit acoustic reports. It is more appropriate to define the 
stress-strain curve in terms of a linear elastic region, and a nonlinear progressive delamination region.

\subsection{Test Results}

Data for the warp direction specimens are presented in Table 2, and data for the fill direction are presented in Table 3. Each value in the table presented here is the average of ten tests, as ten specimens each in the warp direction and ten in the fill direction were tested for each panel. The data in Tables 2 and 3 are given in order of increasing Teflon, and show values for the maximum stress, standard deviation for the maximum stress, flexural modulus, standard deviation for the modulus, strain at the yield point, and strain at the break point. 
Table 2. Warp Direction 3-point Bend Test Data

\begin{tabular}{|c|c|c|c|c|c|c|c|}
\hline ID & $\begin{array}{l}\text { FEP } \\
(\%)\end{array}$ & $\begin{array}{l}\sigma_{\max } \\
(\mathrm{MPa})\end{array}$ & $\begin{array}{c}\sigma_{\max } \\
\text { Std.Dev. } \\
(\%) \\
\end{array}$ & $\begin{array}{c}\text { Flexural } \\
\text { Modulus } \\
\text { (MPa) }\end{array}$ & $\begin{array}{c}\text { Modulus } \\
\text { Std.Dev. } \\
(\%)\end{array}$ & $\begin{array}{c}\varepsilon_{y} \\
(\mathrm{~mm} / \mathrm{mm})\end{array}$ & $\begin{array}{c}\varepsilon_{b} \\
(\mathrm{~mm} / \mathrm{mm})\end{array}$ \\
\hline $\mathrm{Aa}$ & 0 & 795.4 & 5.6 & 83890 & 1.7 & .0166 & .0166 \\
\hline $\mathrm{Ea}$ & 0 & 747.0 & 5.6 & 81720 & 0.9 & .0162 & .0161 \\
\hline $\mathrm{Ma}$ & 0 & 772.9 & 6.0 & 82510 & 1.8 & .0165 & .0165 \\
\hline $\mathrm{Ra}$ & 0 & 750.2 & 5.3 & 82650 & 1.1 & .0160 & .0160 \\
\hline $\mathrm{Na}$ & 1.14 & 764.3 & 5.3 & 82570 & 1.9 & .0158 & .0163 \\
\hline $\mathrm{Ca}$ & 1.16 & 774.3 & 2.9 & 82250 & 0.9 & .0160 & .0164 \\
\hline $\mathrm{Fa}$ & 1.28 & 723.8 & 3.8 & 80150 & 1.8 & .0147 & .0160 \\
\hline $\mathrm{Ba}$ & 1.99 & 756.5 & 7.2 & 82870 & 1.5 & .0145 & .0163 \\
\hline $\mathrm{Oa}$ & 2.02 & 750.2 & 5.3 & 81470 & 3.1 & .0153 & .0165 \\
\hline $\mathrm{Ga}$ & 2.17 & 726.8 & 4.9 & 81266 & 0.6 & .0134 & .0157 \\
\hline $\mathrm{Sa}$ & 2.18 & 774.3 & 7.1 & 83290 & 2.6 & .0162 & .0167 \\
\hline $\mathrm{Pa}$ & 4.04 & 699.6 & 3.2 & 78850 & 1.3 & .0128 & .0158 \\
\hline $\mathrm{Ta}$ & 4.08 & 749.1 & 4.8 & 82070 & 1.7 & .0157 & .0160 \\
\hline $\mathrm{Ha}$ & 4.13 & 693.2 & 5.0 & 83260 & 1.4 & .0120 & .0152 \\
\hline$D$ & 4.25 & 660.9 & 6.5 & 81630 & 1.1 & .0124 & .0151 \\
\hline $\mathrm{O}$ & 6.16 & 692.7 & 8.2 & 80930 & 1.3 & .0128 & .0157 \\
\hline
\end{tabular}

Note: Each data entry represents an average of ten specimens. 
Table 3. Fill Direction 3-point Bend Test Data

\begin{tabular}{|c|c|c|c|c|c|c|c|}
\hline ID & FEP & $\sigma_{\max }$ & $\begin{array}{c}\sigma_{\max } \\
\text { (MPa) }\end{array}$ & $\begin{array}{c}\text { Flexural } \\
(\%)\end{array}$ & $\begin{array}{c}\text { Modulus } \\
\text { Modulus } \\
\text { Std.Deva) }\end{array}$ & $\begin{array}{c}\varepsilon_{\mathrm{y}} \\
(\%)\end{array}$ & $\varepsilon_{\mathrm{b}}$ \\
\hline Ac-d & 0 & 823.8 & 5.9 & 88180 & 0.9 & .0165 & .0165 \\
\hline Ec-d & 0 & 822.9 & 3.9 & 84420 & 1.4 & .0172 & .0172 \\
\hline Mc-d & 0 & 743.9 & 6.4 & 84560 & 1.7 & .0156 & .0155 \\
\hline Rc-d & 0 & 862.0 & 3.0 & 85370 & 1.9 & .0176 & .0178 \\
\hline Nc-d & 1.14 & 690.6 & 3.8 & 82990 & 1.2 & .0145 & .0146 \\
\hline Cc-d & 1.16 & 743.1 & 6.6 & 84700 & 2.1 & .0154 & .0154 \\
\hline Fc-d & 1.28 & 729.0 & 6.8 & 84850 & 1.2 & .0152 & .0151 \\
\hline Bc-d & 1.99 & 757.9 & 4.4 & 87950 & 1.3 & .0148 & .0151 \\
\hline Oc-d & 2.02 & 673.3 & 4.9 & 83200 & 1.5 & .0138 & .0146 \\
\hline Gc-d & 2.17 & 626.0 & 5.9 & 82460 & 1.4 & .0132 & .0132 \\
\hline Sc-d & 2.18 & 705.2 & 8.3 & 84290 & 3.0 & .0146 & .0148 \\
\hline Pc-d & 4.04 & 655.1 & 4.9 & 82620 & 1.9 & .0134 & .0142 \\
\hline Tc-d & 4.08 & 697.5 & 5.7 & 85820 & 2.0 & .0141 & .0153 \\
\hline Hc-d & 4.13 & 663.5 & 3.0 & 86750 & 1.0 & .0135 & .0134 \\
\hline Dc-d & 4.25 & 661.2 & 4.6 & 83960 & 1.4 & .0133 & .0138 \\
\hline Oc-d & 6.16 & 676.5 & 3.8 & 83160 & 1.4 & .0139 & .0145 \\
\hline
\end{tabular}

Note: Each data entry represents an average of ten specimens. 
All samples fractured in a manner characteristic of a generally brittle material, and with a considerable amount of scatter in the data. The amount of scatter in the data was measured by the standard deviations in the averages of the strength and flexural moduli. As shown in Tables 2 and 3 , the standard deviations did not increase with added Teflon in either the warp or fill directions. This implies that adding the Tefion powder did not increase the inherent defect population caused by the manufacturing process. Inherent defects, such as broken fibers, voids, laminae misalignment, rough cutting edges, or contamination, are largely responsible for variations in the test data that are observed in all test samples. Frequently, a measure of the processing quality is the standard deviation of the average of the test samples. A large value in the standard deviation implies non-uniformity, and random defects in the material, which leads to scatter in the test data. This shows that the measured effects were not biased by additional factors in the sample fabrication process, and indicates that the additions of Tefion were uniform at least on a macroscopic scale.

Toughness and damage tolerance values in terms of $\Delta \varepsilon$, fracture energy, and total failure energy, were calculated from the data in Tables 2, and 3. These values are presented in Table 4 for the warp direction, and Table 5 for the fill direction. In Tables 2 and 3 some of the $\varepsilon_{b}$ values are larger than the $\varepsilon_{y}$ values. This is typically the case for brittle specimens, and is a result of the 
programming used to detect the yield and break points on the instrumented mechanical test machine, as explained in Section 4.7. When $\varepsilon_{b}$ is larger than $\varepsilon_{y}$ it results in a negative value for $\Delta \varepsilon$, which then results in a negative value for the fracture energy, $\Delta \varepsilon \times \sigma_{\mathrm{b}}$. This is avoided by recognizing that in reality there is no additional strain, and $\varepsilon_{b}$ is equal to $\varepsilon_{y}$, meaning that we may simply assign a zero value to $\Delta \varepsilon$. 
Table 4. Warp Direction, With Calculations for Toughness and Damage Tolerance

\begin{tabular}{|c|c|c|c|c|c|c|}
\hline $\mathrm{ID}$ & $\mathrm{FEP}$ & $\Delta \varepsilon$ & $\sigma_{\mathrm{b}}$ & $\Delta \varepsilon \times \sigma_{\mathrm{b}}$ & Resilience & $\begin{array}{c}\text { Total } \\
(\%)\end{array}$ \\
$(\mathrm{mm} / \mathrm{mm})$ & $(\mathrm{MPa})$ & $\left(\mathrm{MJ}^{2} \mathrm{~m}^{3}\right)$ & $\left(\mathrm{MJ} / \mathrm{m}^{3}\right)$ & $\begin{array}{c}\text { Energy } \\
\left(\mathrm{MJ}^{\prime} \mathrm{m}^{3}\right)\end{array}$ \\
\hline $\mathrm{Aa}$ & 0 & 0 & 767.5 & 0 & 6.602 & 6.602 \\
\hline $\mathrm{Ea}$ & 0 & 0 & 745.2 & 0 & 6.051 & 5.976 \\
\hline $\mathrm{Ma}$ & 0 & 0 & 760.9 & 0 & 6.376 & 6.376 \\
\hline $\mathrm{Ra}$ & 0 & 0 & 748.2 & 0 & 6.002 & 6.002 \\
\hline $\mathrm{Na}$ & 1.14 & 0.0005 & 762.3 & 0.381 & 6.038 & 6.419 \\
\hline $\mathrm{Ca}$ & 1.16 & 0.0004 & 768.8 & 0.308 & 6.194 & 6.502 \\
\hline $\mathrm{Fa}$ & 1.28 & 0.0013 & 720.8 & 0.937 & 5.320 & 6.257 \\
\hline $\mathrm{Ba}$ & 1.99 & 0.0018 & 724.8 & 1.305 & 5.485 & 6.789 \\
\hline $\mathrm{Oa}$ & 2.02 & 0.0012 & 735.6 & 0.883 & 5.739 & 6.622 \\
\hline $\mathrm{Ga}$ & 2.17 & 0.0023 & 712.7 & 1.639 & 4.870 & 6.509 \\
\hline $\mathrm{Sa}$ & 2.18 & 0.0005 & 767.1 & 0.384 & 6.272 & 6.655 \\
\hline $\mathrm{Pa}$ & 4.04 & 0.003 & 691.0 & 2.073 & 4.477 & 6.550 \\
\hline $\mathrm{Ta}$ & 4.08 & 0.0003 & 734.0 & 0.220 & 5.880 & 6.101 \\
\hline $\mathrm{Ha}$ & 4.13 & 0.0032 & 665.0 & 2.128 & 4.159 & 6.287 \\
\hline $\mathrm{Da}$ & 4.25 & 0.0027 & 612.5 & 1.654 & 4.098 & 5.751 \\
\hline $\mathrm{Ca}$ & 6.16 & 0.0029 & 657.9 & 1.908 & 4.433 & 6.341 \\
\hline
\end{tabular}

Note: Each data entry represents an average of ten specimens. 
Table 5. Fill Direction, With Calculations for Toughness and Damage Tolerance

\begin{tabular}{|c|c|c|c|c|c|c|}
\hline ID & $\begin{array}{c}\text { FEP } \\
(\%)\end{array}$ & $\Delta \varepsilon$ & $\sigma_{\mathrm{b}}$ & $\Delta \varepsilon \times \sigma_{\mathrm{b}}$ & Resilience & Total \\
$(\mathrm{mm} / \mathrm{mm})$ & $(\mathrm{MPa})$ & $\left(\mathrm{MJ}^{3} \mathrm{~m}^{3}\right)$ & $\left(\mathrm{MJ} / \mathrm{m}^{3}\right)$ & $\begin{array}{c}\text { Energy } \\
\left(\mathrm{MJ}^{3} \mathrm{~m}^{3}\right.\end{array}$ \\
\hline Ac-d & 0 & 0 & 809.4 & 0 & 6.796 & 6.796 \\
\hline Ec-d & 0 & 0 & 821.6 & 0 & 7.077 & 7.077 \\
\hline Mc-d & 0 & 0 & 742.2 & 0 & 5.802 & 5.728 \\
\hline Rc-d & 0 & 0.0002 & 860.2 & 0.172 & 7.586 & 7.758 \\
\hline Nc-d & 1.14 & 0 & 688.8 & 0.069 & 5.007 & 5.076 \\
\hline Cc-d & 1.16 & 0 & 738.6 & 0 & 5.722 & 5.722 \\
\hline Fc-d & 1.28 & 0 & 726.1 & 0 & 5.540 & 5.468 \\
\hline Bc-d & 1.99 & 0.0003 & 747.0 & 0.224 & 5.608 & 5.833 \\
\hline Oc-d & 2.02 & 0.0008 & 654.5 & 0.524 & 4.646 & 5.169 \\
\hline Gc-d & 2.17 & 0 & 616.5 & 0 & 4.132 & 4.132 \\
\hline Sc-d & 2.18 & 0.0002 & 690.6 & 0.138 & 5.148 & 5.286 \\
\hline Pc-d & 4.04 & 0.0006 & 643.6 & 0.515 & 4.389 & 4.904 \\
\hline Tc-d & 4.08 & 0.0012 & 673.9 & 0.809 & 4.917 & 5.726 \\
\hline Hc-d & 4.13 & 0 & 661.6 & 0 & 4.479 & 4.413 \\
\hline Dc-d & 4.25 & 0.0005 & 641.6 & 0.321 & 4.397 & 4.718 \\
\hline Qc-d & 6.16 & 0.0006 & 652.2 & 0.391 & 4.702 & 5.093 \\
\hline
\end{tabular}

Note: Each data entry represents an average of ten specimens. 
It is evident from Table 4 that for the warp direction, an increase in $\Delta \varepsilon$ and fracture energy $\left(\Delta \varepsilon \times \sigma_{b}\right)$ is produced by adding Teflon powder. Table 5 shows that for the fill direction $\Delta \varepsilon$ and fracture energy increases are slight. Tables 4 and 5 also show the total failure energy, which is the fracture energy plus the resilience. The resilience is defined as the work to strain the specimen elastically. It is shown that for the warp direction the total energy is a slightly decreasing function of added Teflon, but for the fill direction the total energy decreases a much larger degree, primarily because of the decrease in $\sigma_{\max }$.

Examples of stress-strain curves for some representative warp direction specimens are shown in Figures 21, 22, and 23. Examples of stress-strain curves for some representative fill direction specimens are shown in Figures 24, 25, and 26. 


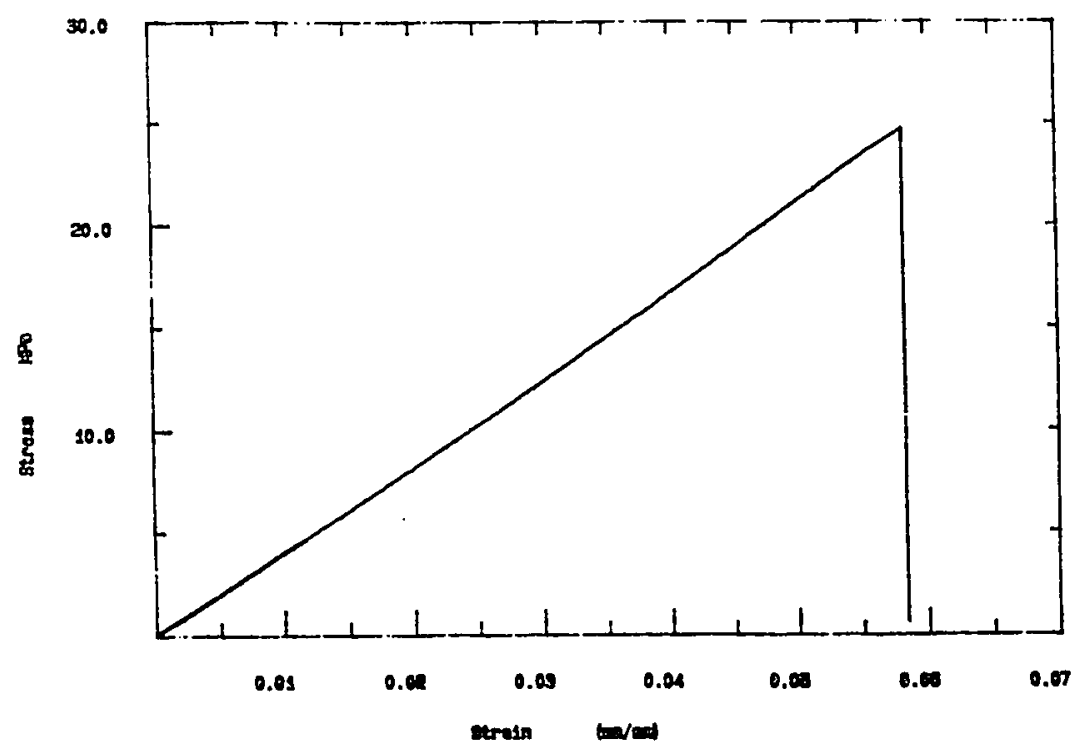

Figure 21. Stress-Strain Curve for a Warp Direction Specimen from Panel A with $0 \%$ Teflon

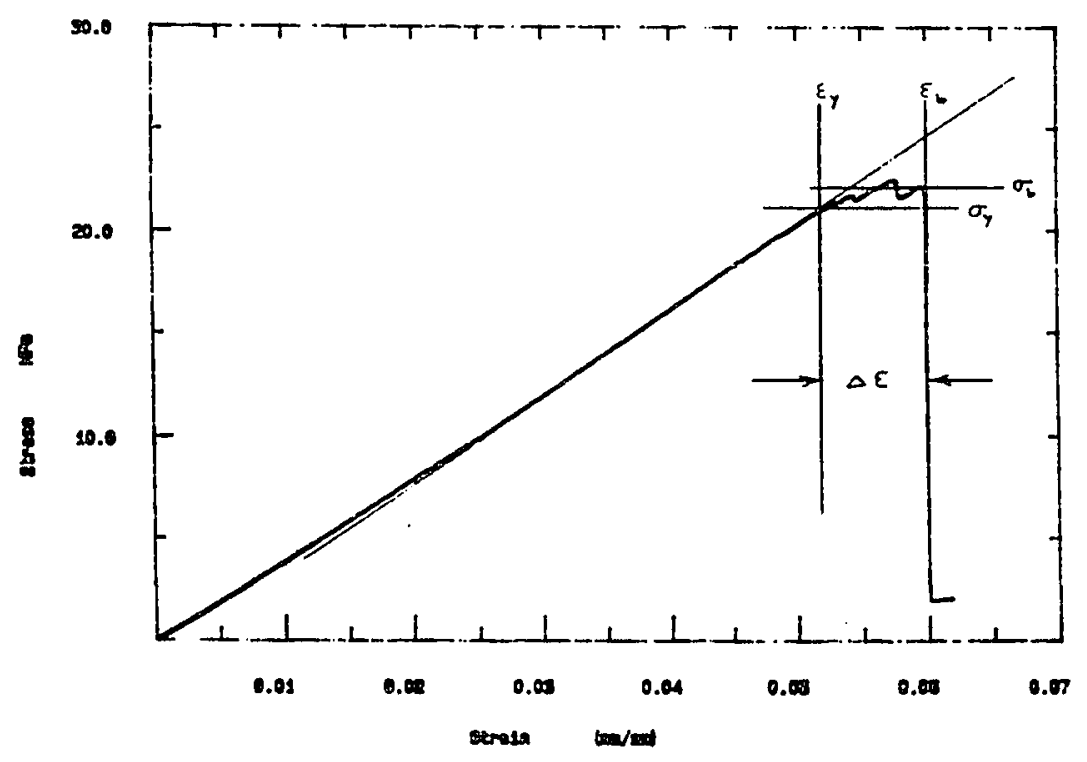

Figure 22. Stress-Strain Curve for a Warp Direction Specimen from Panel $F$ with $1 \%$ Teflon 


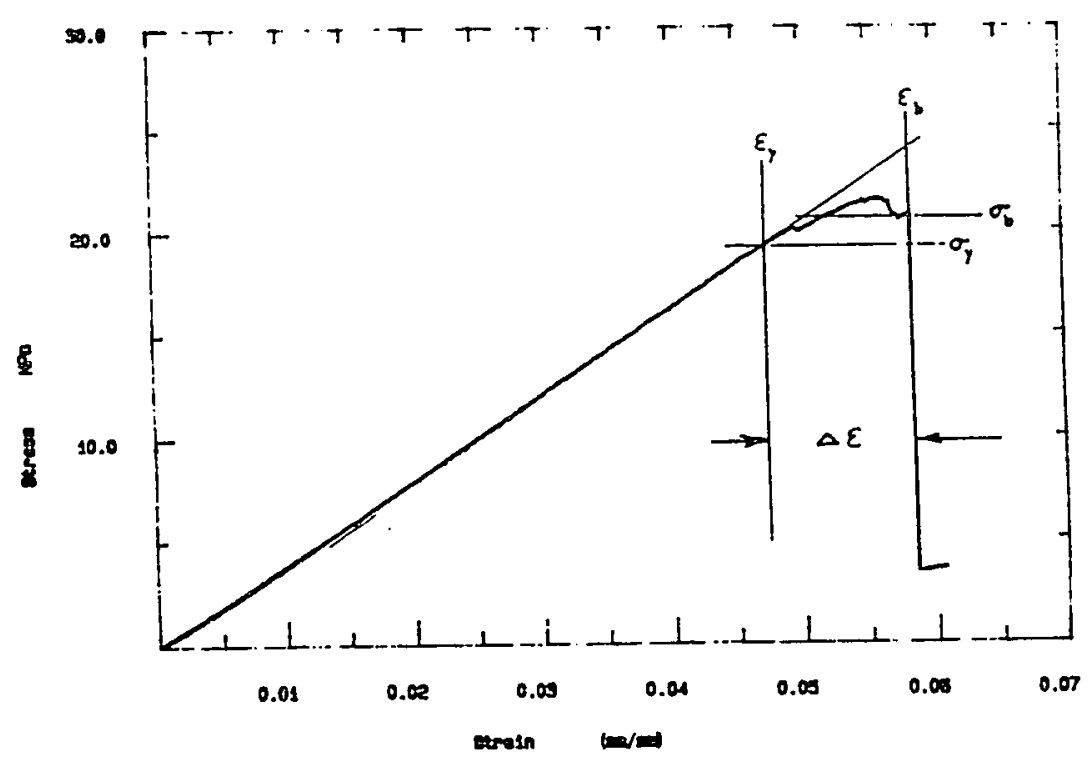

Figure 23. Siress-Strain Curve for a Warp Direction Specimen from Panel $P$ with $4 \%$ Teflon

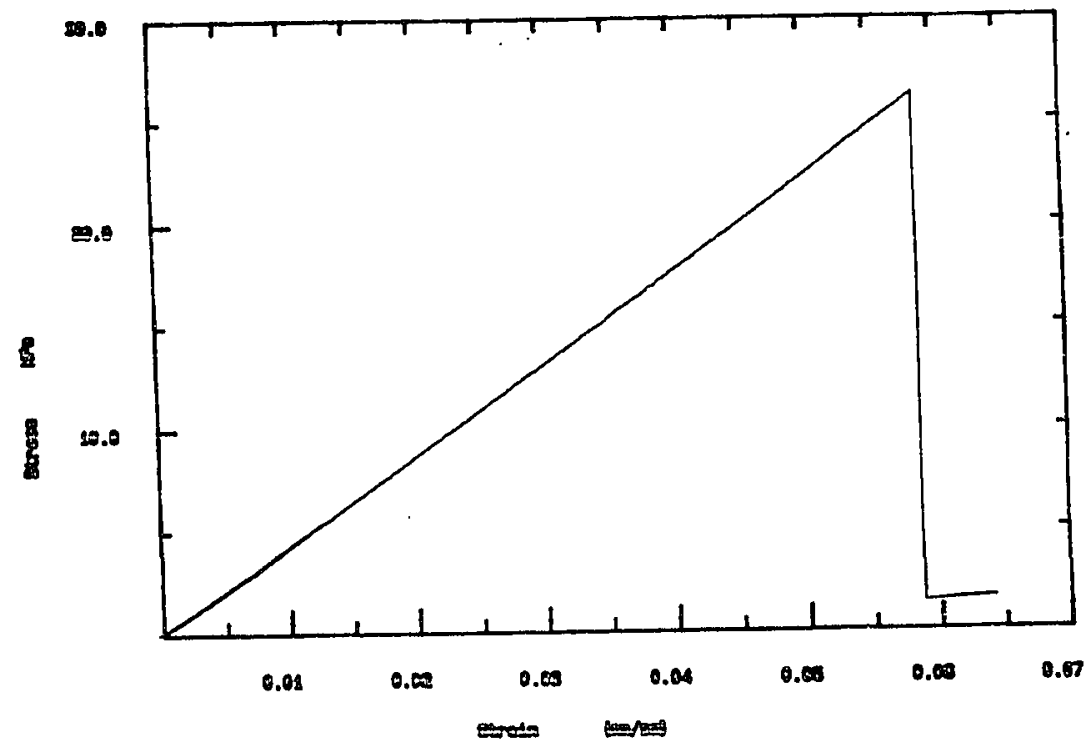

Figure 24. Stress-Strain Curve for a Fill Direction Specimen from Panel A with 0\% Teflon 


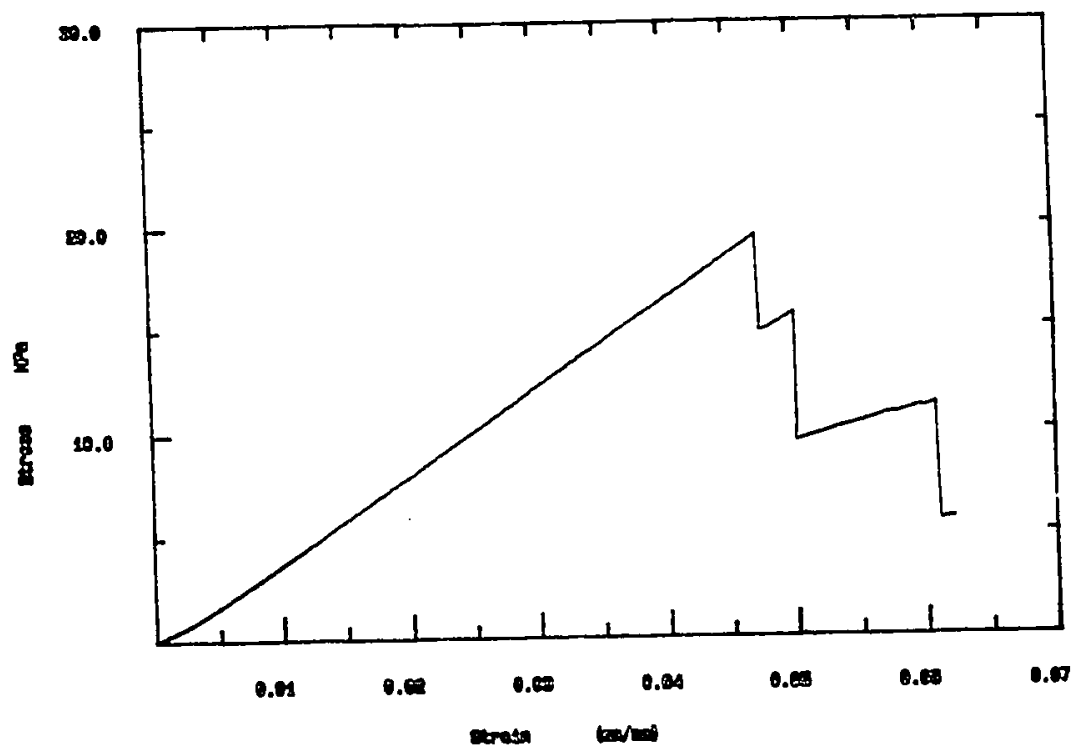

Figure 25. Stress-Strain Curve for a Fill Direction Specimen from Panel $O$ with $2 \%$ Teflon

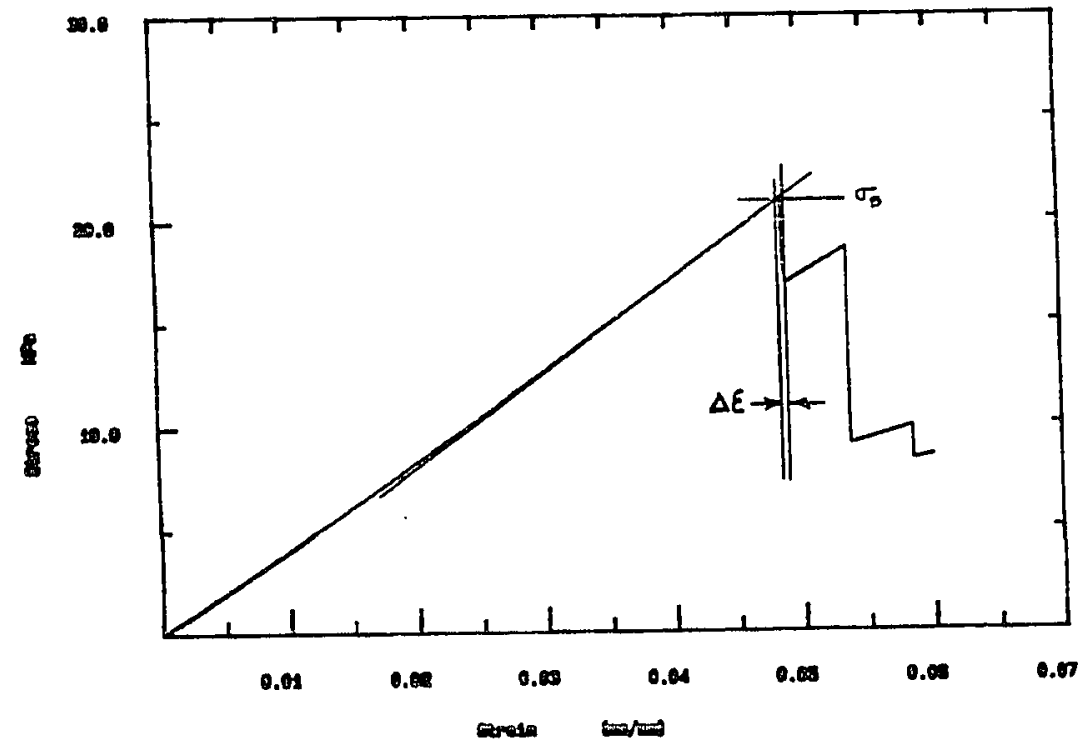

Figure 26. Stress-Strain Curve for a Fill Direction Specimen from Panel D with 4\% Tefion 
Figure 21 shows a brittle fracture with no measurable strain past the yield point. This graph is from a warp direction specimen from panel A, with $0 \%$ added Tefion. The GFRP has properties as expected and provides essentialiy no fracture energy. This is typical of all the control samples. Figure 22 shows a well behaved linear portion, but with $1 \%$ Tefion added the specimen now shows progressive delamination producing additional strain after the point of deviation from the linear elastic portion. As explained in Section 4.8, this is measured as $\Delta \varepsilon$ and represents damage tolerance in the material. Also evident in Figure 22 is that the strength of the specimen, $\sigma_{\max }$, is slightly decreased from the control sample. Figure 23 shows even greater $\Delta \varepsilon$ with $4 \%$ added Tefion. This specimen also shows that when initial cracking begins, the curve deviates from the straight line portion, but there is still additional stress that can be supported by the specimen. This is evident by $\sigma_{b}$ being greater than $\sigma_{y}$. This is representative of specimens containing higher concentrations of Teflon. Warp direction specimens in the experiment clearly have greater values of $\Delta \varepsilon$ with added Tefion powder.

Specimens in the fill direction also show an increase in $\Delta \varepsilon$ with added Tefion, but to a lesser degree. Figure 24, with $0 \%$ Teflon, shows the brittle characteristics typical of GFRP with no 
measurable toughness in the non-elastic region. Figure 25 , with $2 \%$ Tefion, shows a specimen with a very small amount of $\Delta \varepsilon$, such that it is not readily measured. This figure shows a typical example of a fill direction specimen where progressive delamination does not occur. Instead, an incomplete fracture causes a large drop in the stress, and the material continues io deflect aî a lower load. Even though the material does not fail, the drop in the stress is large enough to be detected by the Instron as the break point, so the Instron does not measure any $\Delta \varepsilon$. At higher Teflon concentrations the fill direction specimens do show some small increase in damage tolerance, as shown by Figure 26.

\subsection{Toughness and Damage Tolerance Evaluation}

Damage tolerance, in terms of strain after yield and beiore failure, and toughness in terms of the total energy required to fracture a specimen, were caiculaied for each panet from the data given in Tables 2 and 3 . The results for additional strain in the warp direction are presented in Figure 27, and for additional strain in the fill direction in Figure 28. The results for energy of fracture in the warp direction are presented in Figure 29, and for energy of fracture in the fill direction in Figure 30 . The total energy of failure for the warp and fill directions is presented in Figures 31 and 32. 


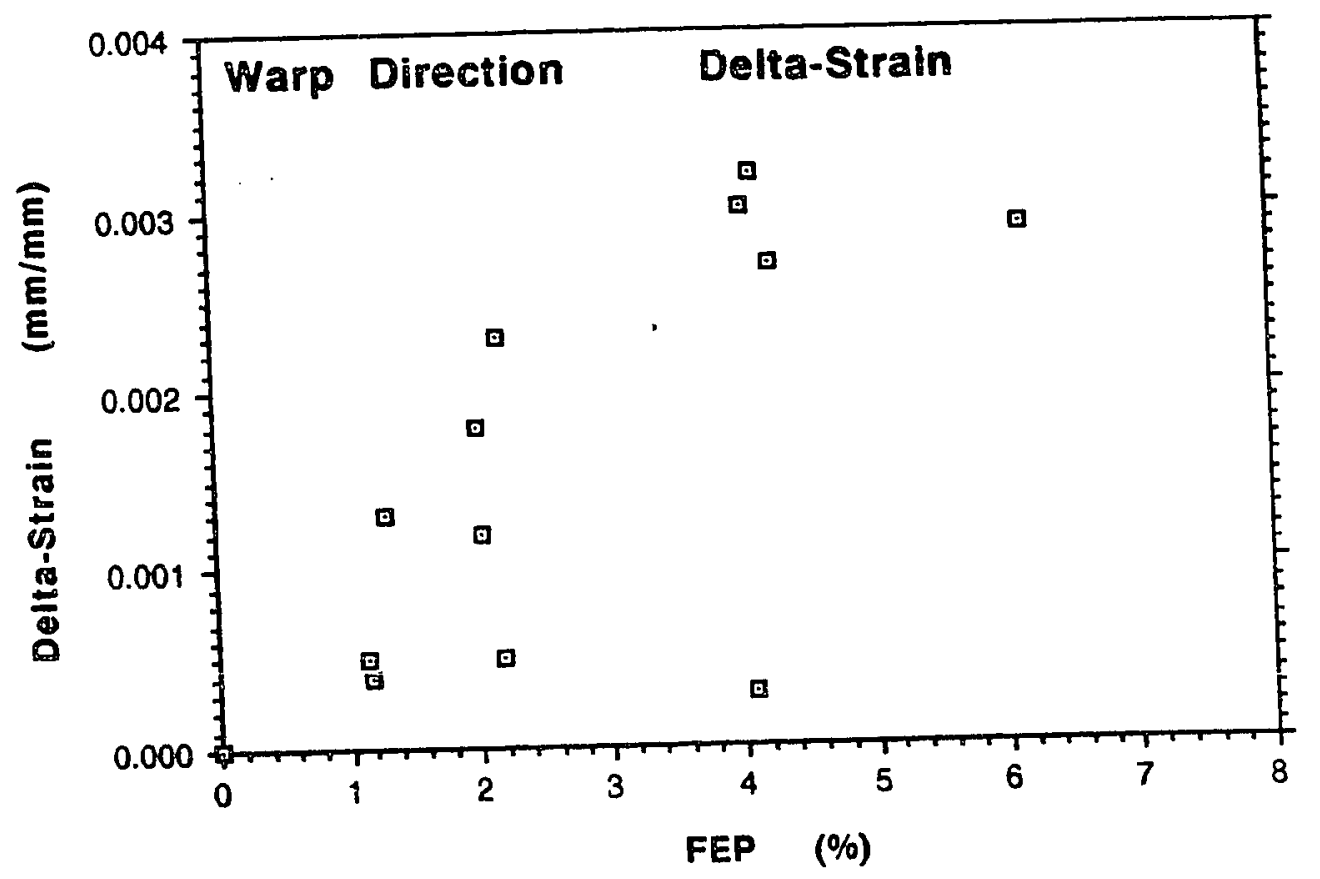

Figure 27. Warp Direction $\Delta \varepsilon$ as a Function of Added Tefion. Note: Each data point represents an average of ten specimens. 


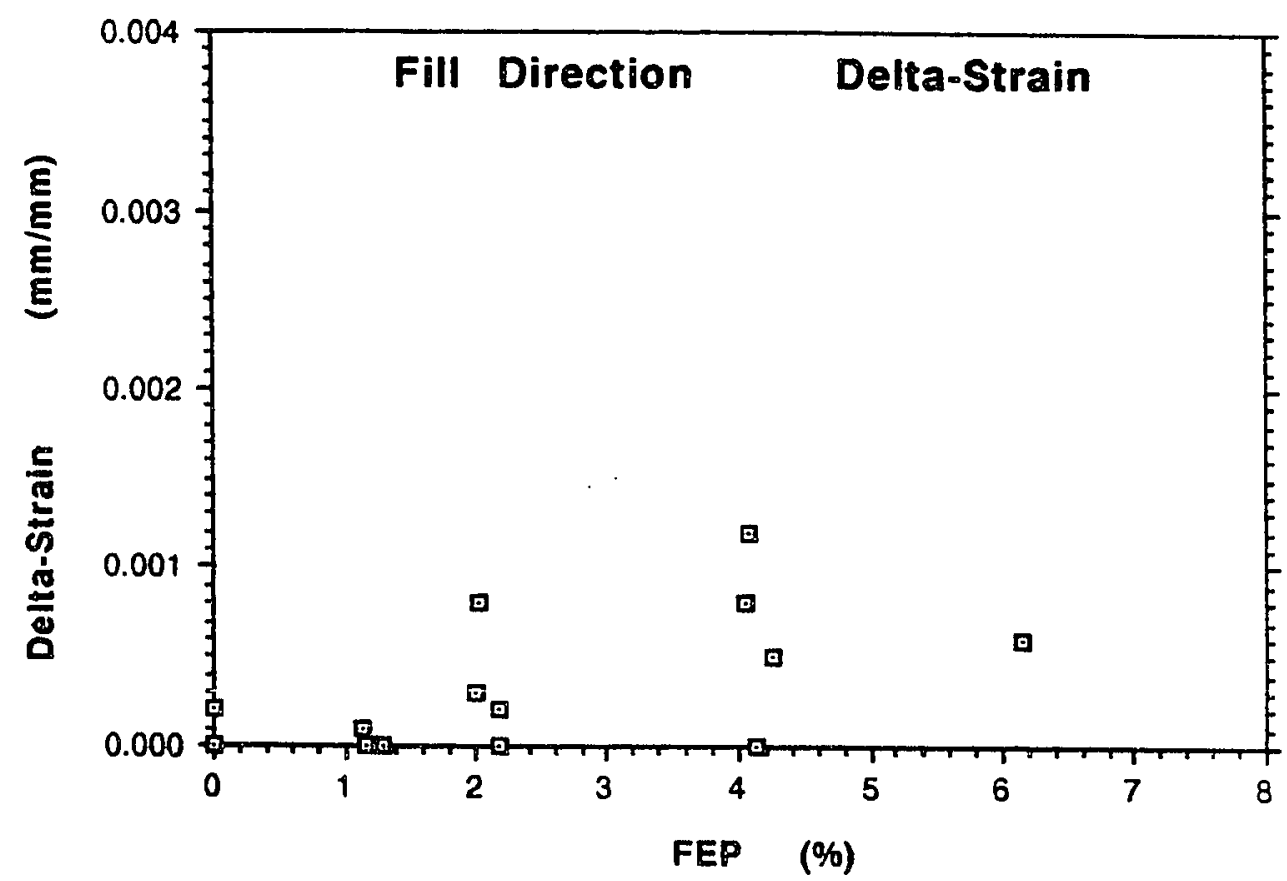

Figure 28. Fill Direction $\Delta \varepsilon$ as a Function of Added Teflon. Note: Each data point represents an average of ten specimens. 


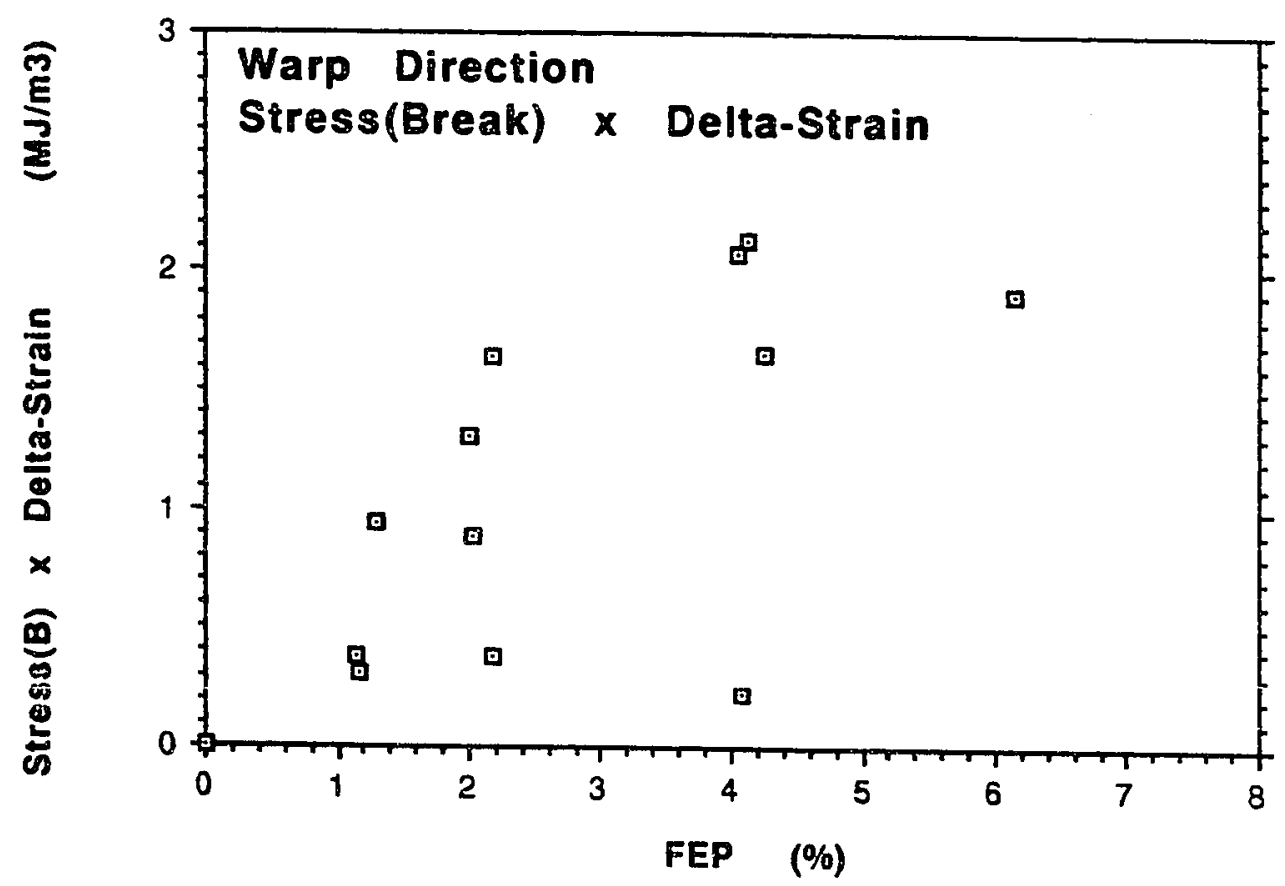

Figure 29. Warp Direction Fracture Energy as a Function of Added Tollon.

Note: Each data point represents an average of ten specimens. 


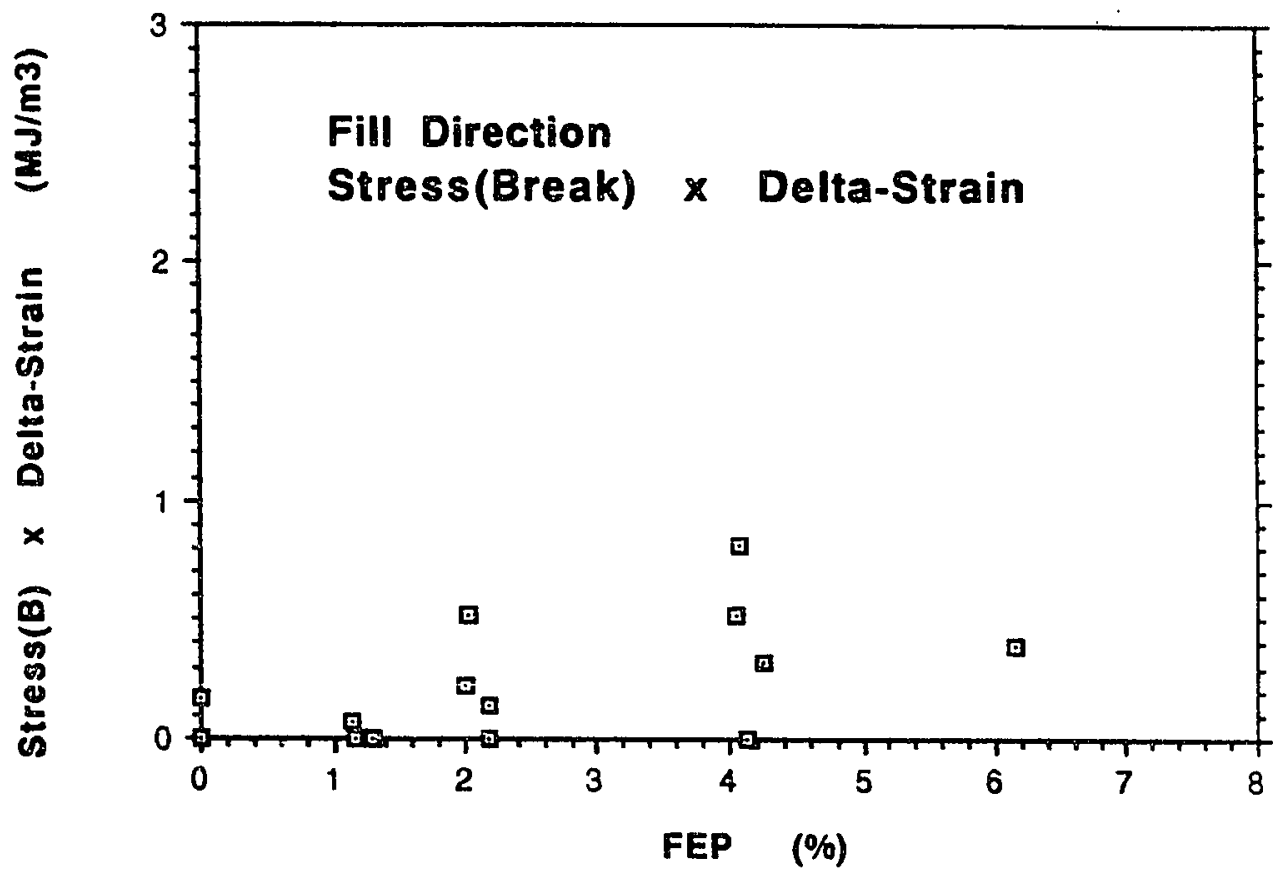

Figure 30. Fill Direction Fracture Energy as a Function of Added Teflon.

Note: Each data point represents an average of ten specimens. 


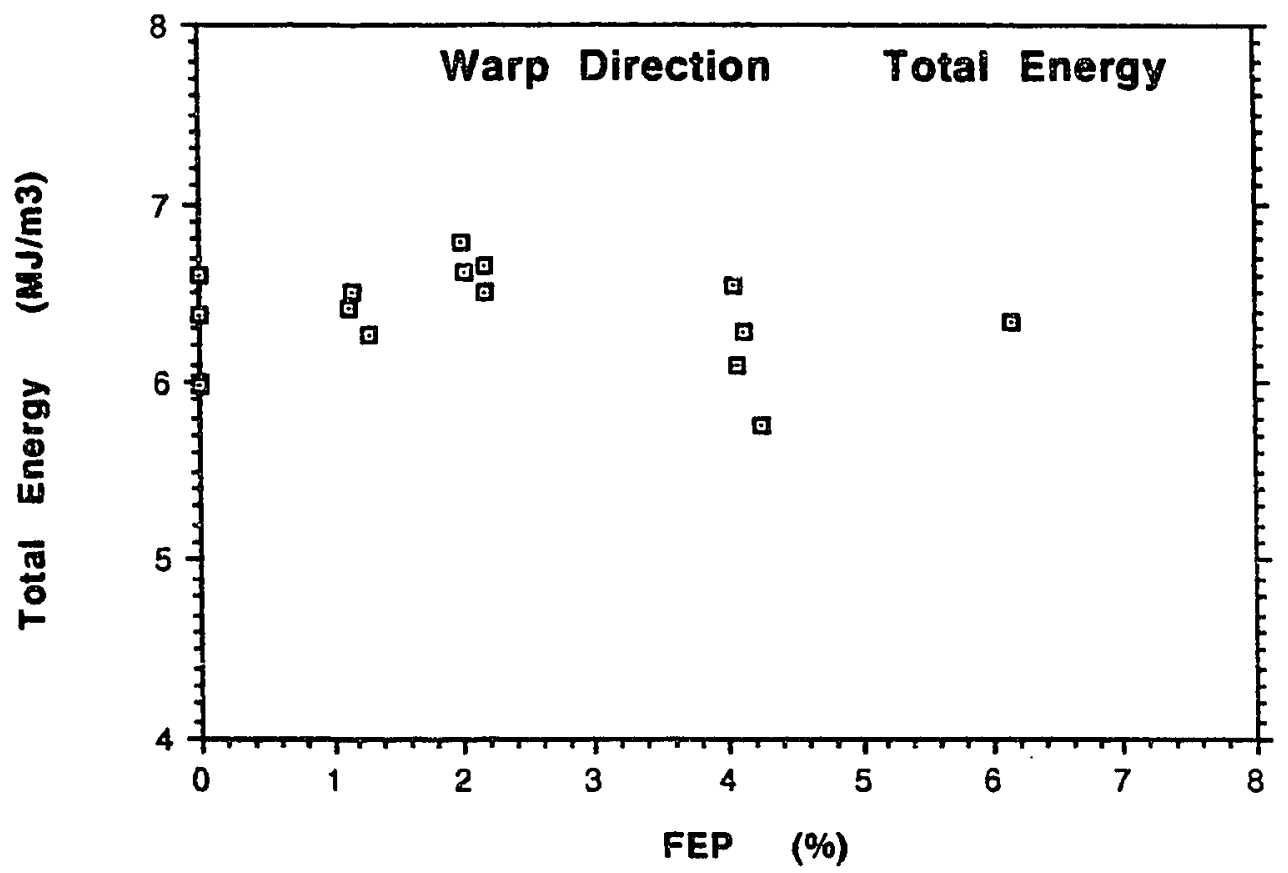

Figure 31. Warp Direction Total Energy of Failure as a Function of Added Tefion. Note: Each data point represents an average of ten specimens. 


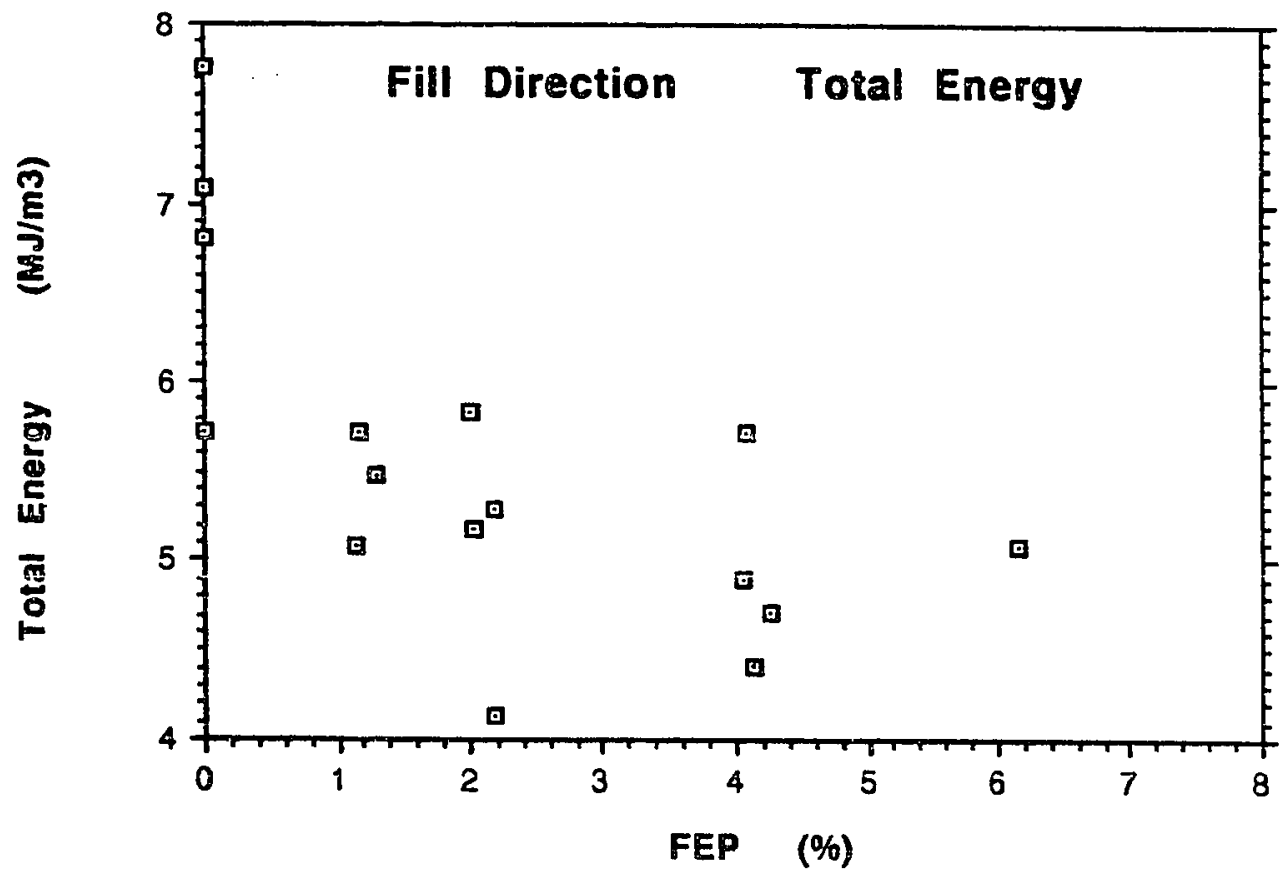

Figure 32. Fill Direction Total Energy of Failure as a Function of Added Teflon.

Note: Each data point represents an average of ten specimens. 
With the addition of Tefion, it can be seen from Figures 27 and 28 that the warp direction has a significant increase in $\Delta \varepsilon$, but in the fill direction the increase is much less. The $\Delta \varepsilon$ starts at essentially zero for the control sample, and for the warp direction increases to an amount roughly $20 \%$ above the amount of elastic strain. In the fill direction the added strain is about $4 \%$ above the elastic strain.

The fracture energy, as defined in section 4.8 as $\Delta \varepsilon \times \sigma_{b}$, is shown to be zero in the control samples in Figures 29 and 30, and increases to roughly $2 \mathrm{MJ} / \mathrm{m}^{3}$ with $4 \%$ added Tefion in the warp direction. In the fill direction the fracture energy increases from zero to roughly $0.5 \mathrm{MJ} / \mathrm{m}^{3}$ with $4 \%$ added Tefion.

\subsection{Effects on Strength and Flexural Modulus}

Figures 33 and 34 show the effects of adding Tefion on the strength in the warp and fill directions, and Figures 35 and 36 show the effects on the flexural modulus in the warp and fill directions. Here it is shown that the strength in the warp direction (Fig. 33) decreases by roughly $7 \%$ with a $4 \%$ addition of Tefion. In the fill direction (Fig. 34) the strength decreases by roughty $13 \%$ with a $4 \%$ addition of Teflon. Fill direction the flexural strengths were found 
to be slightly higher than the warp direction, and delamination occurred more rapidly with the addition of Teflon. The fraciure characteristics in the fill direction are still primarily brittle after the addition of Tefion, as shown in the stress-strain curves of Figures 25, and 26. The flexural modulus for specimens in both directions shows a small decrease of roughly $1 \%$ with the addition of $4 \%$ Teflon.

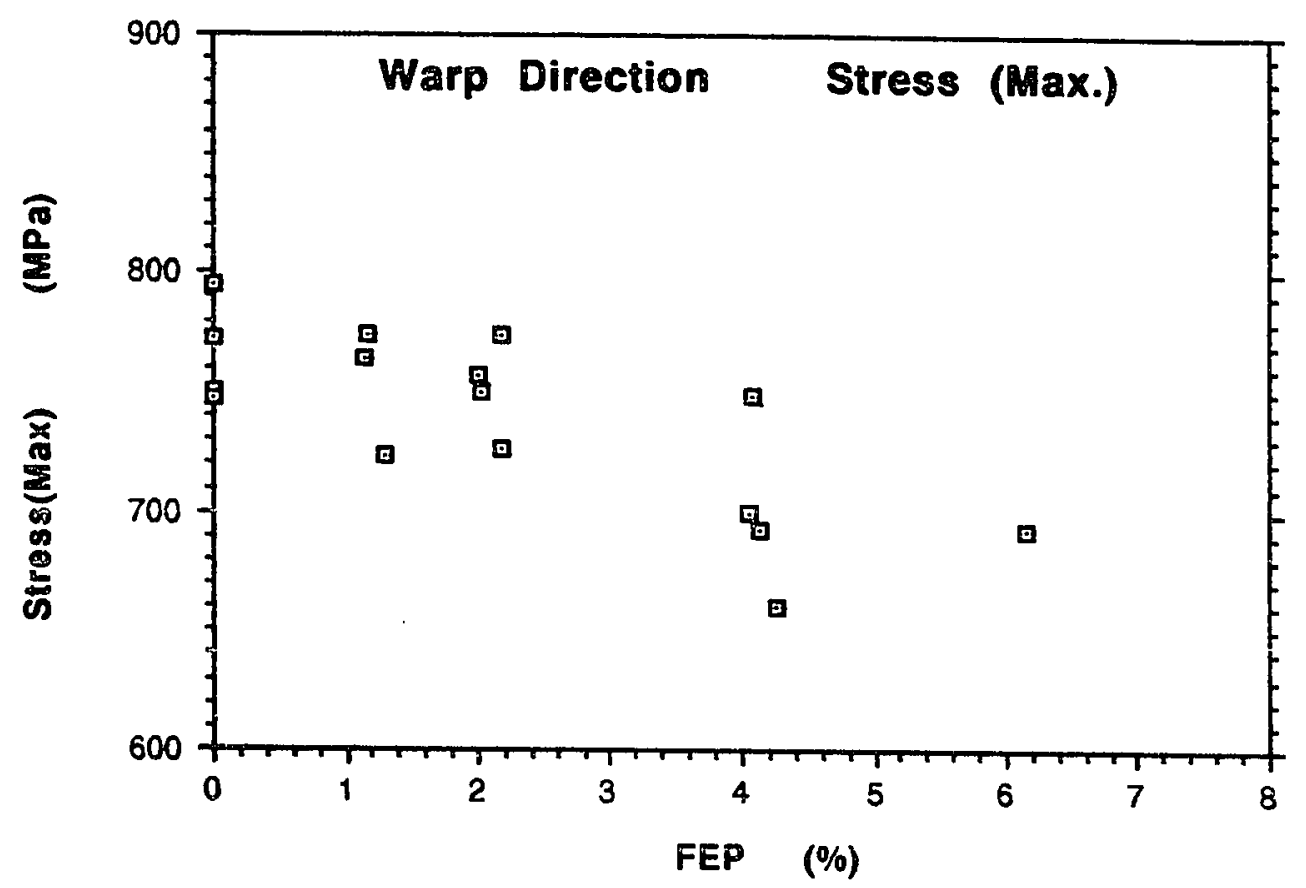

Figure 33. Warp Direction Strength as a Function of Added Tef́lon.

Note: Each data point represents an average of ten specimens. 


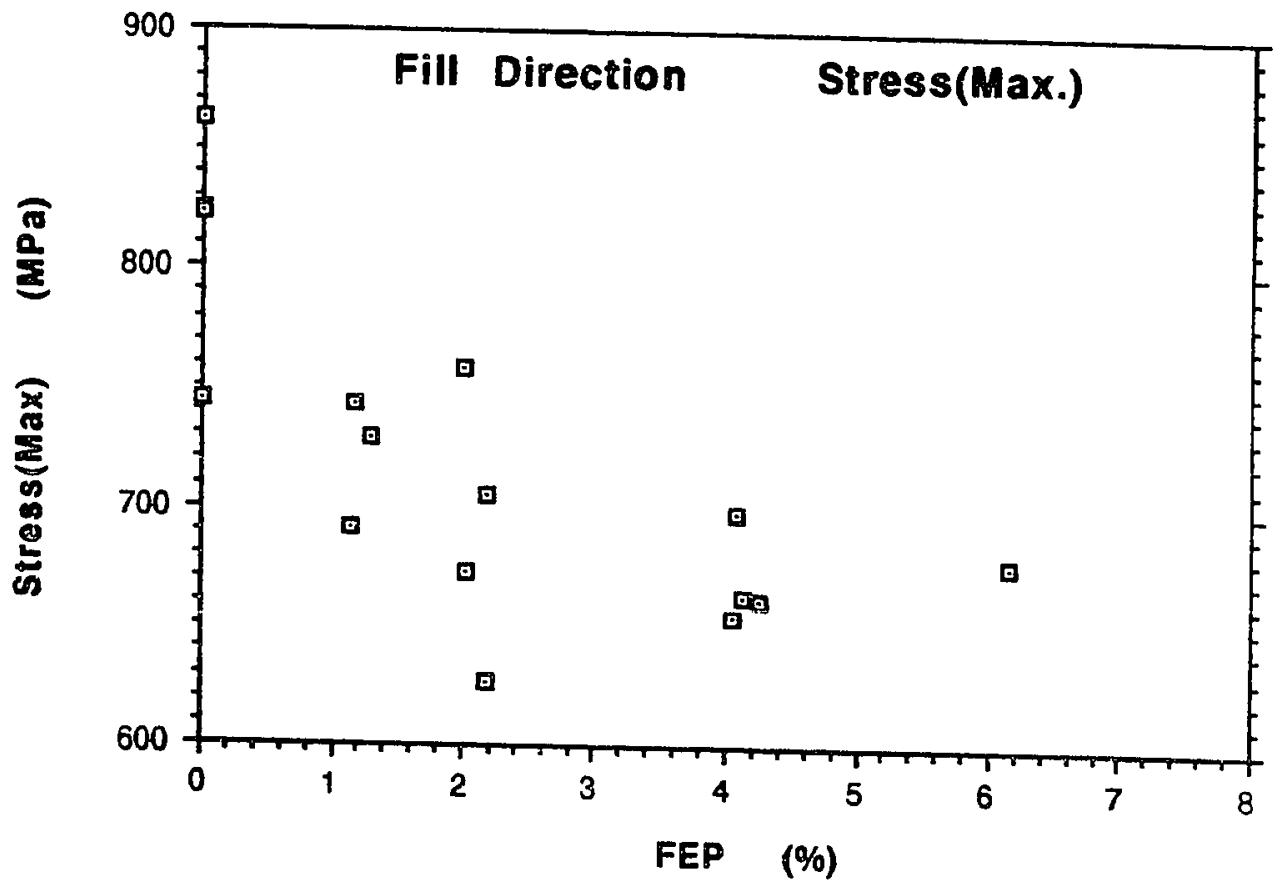

Figure 34. Fill Direction Strength as a Function of Added Toflon.

Note: Each data point represents an average of ten specimens. 


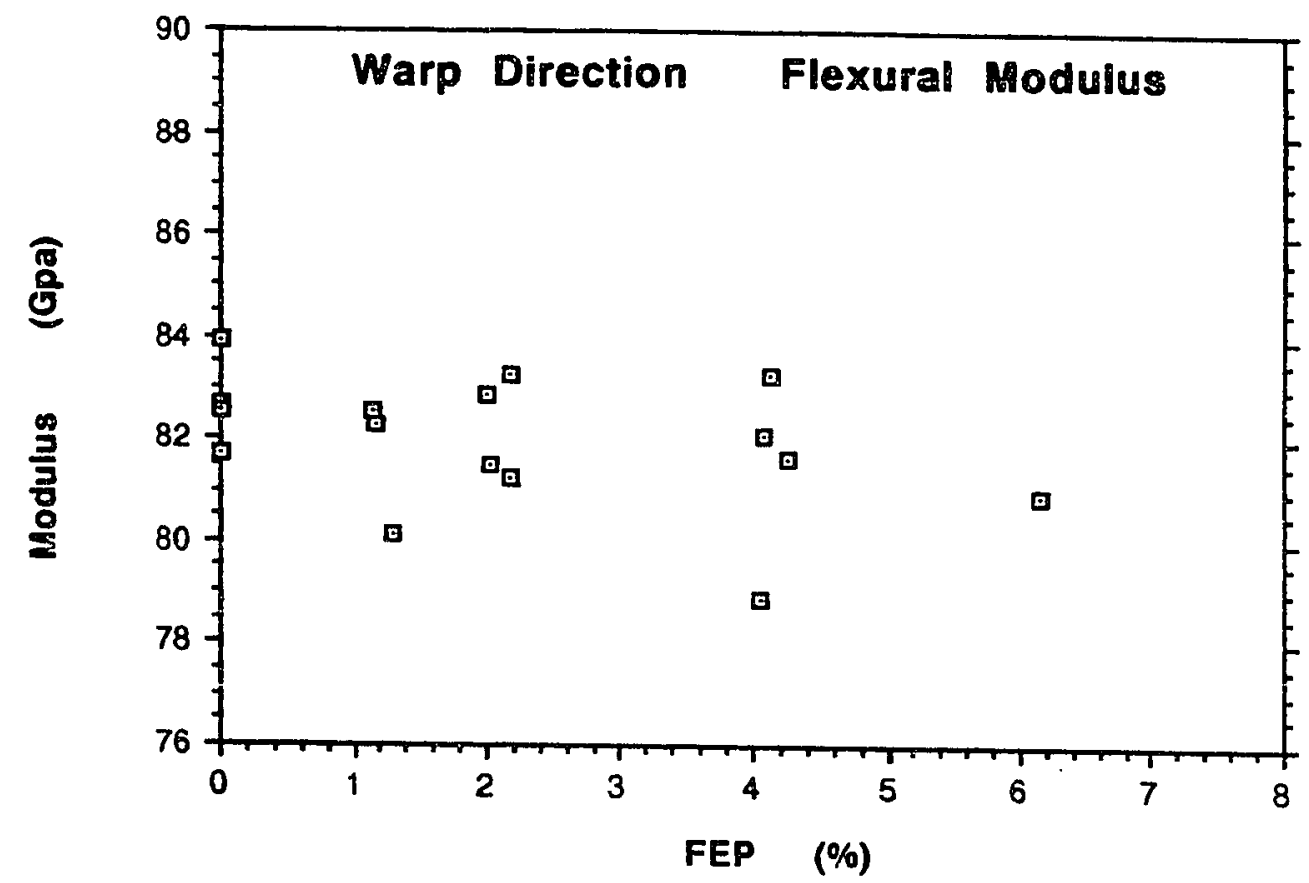

Figure 35. Warp Direction Flexural Modulus as a Function of Added Teflon.

Note: Each data point represents an average of ten specimens. 


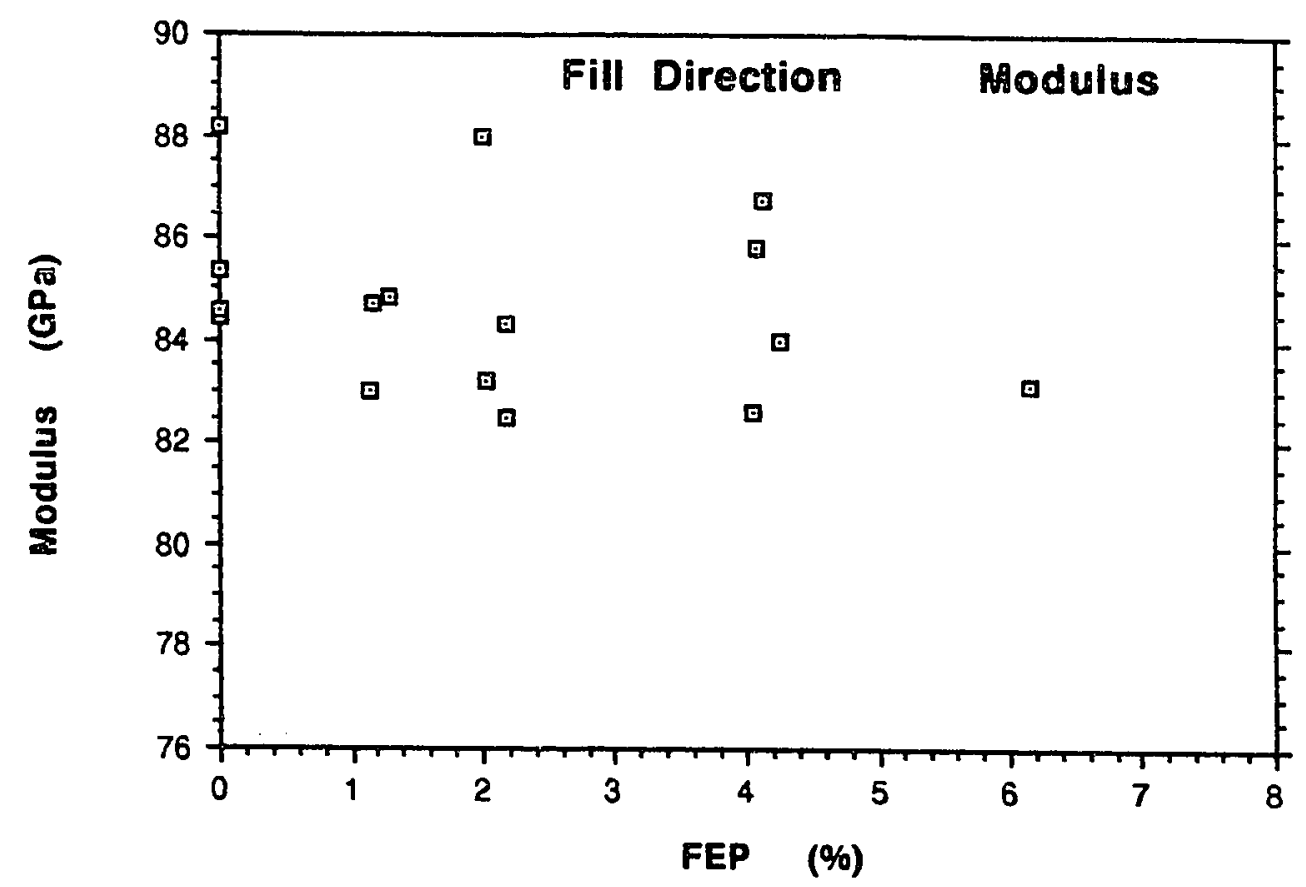

Figure 36. Fill Direction Flexural Modulus as a Function of Added Tefion.

Note: Each data point represents an average of ten specimens.

\subsection{Effects on Panel Thickness and Density}

As the sample panels were fabricated, and Teflon added, each panel was weighed and the thickness measured as part of the test procedure. It was noticed that the density and thickness of the samples increased slightly with the addition of Teflon. The relationship of density and thickness to Tefion amount is shown in Figures 37 and 38 . The reason for the increased thickness was not 
tested, but it is suspected that the very high number of particles in the Tefion powder acted as a filler and increased the resin viscosity. The filled resin did not flow as much during cure, producing slightly thicker panels. The reason for the increased density is primarily due to a rule of mixtures with the Teflon having a higher density than both the fiber and the resin.

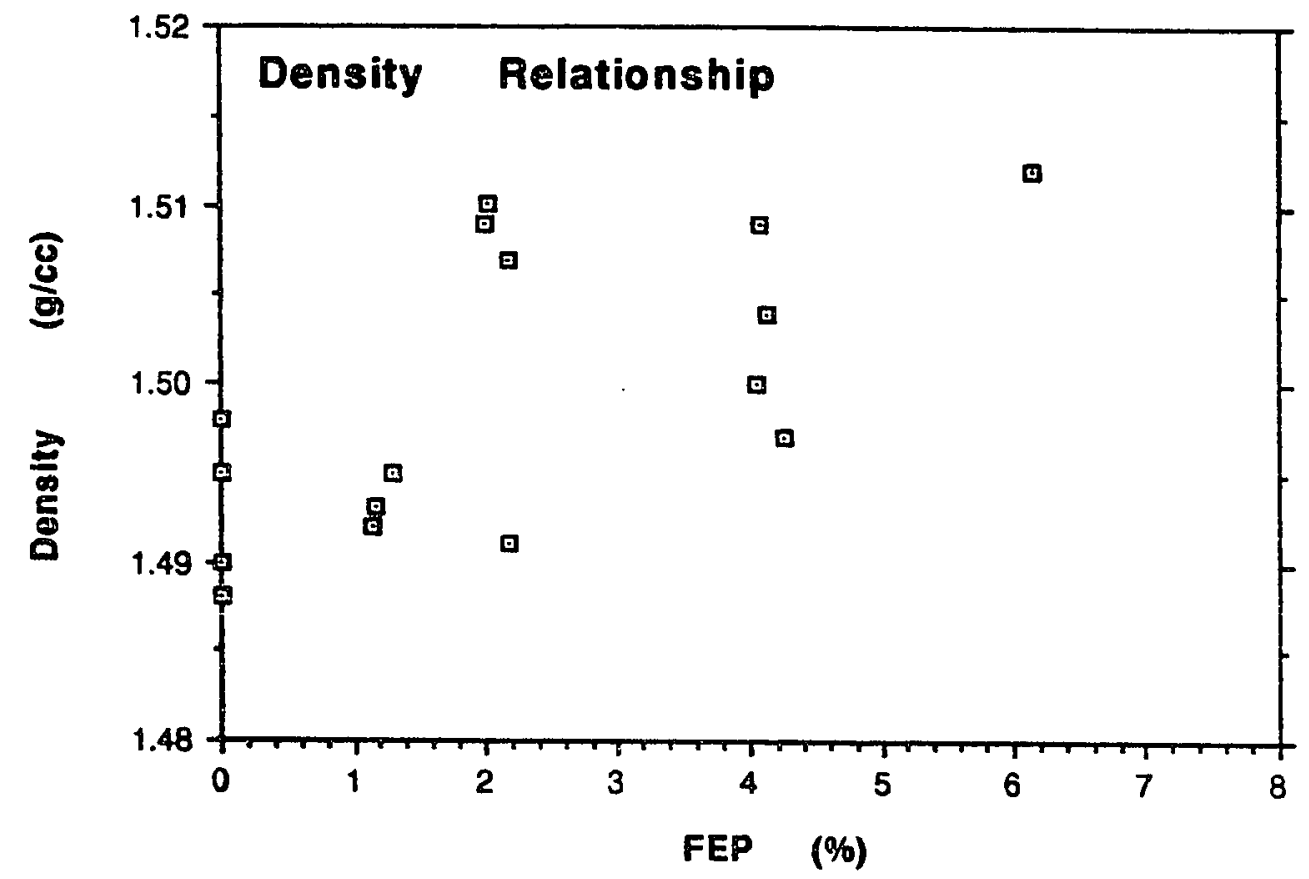

Figure 37. Post-Cure Panel Density as a Function of Added Toflon. 


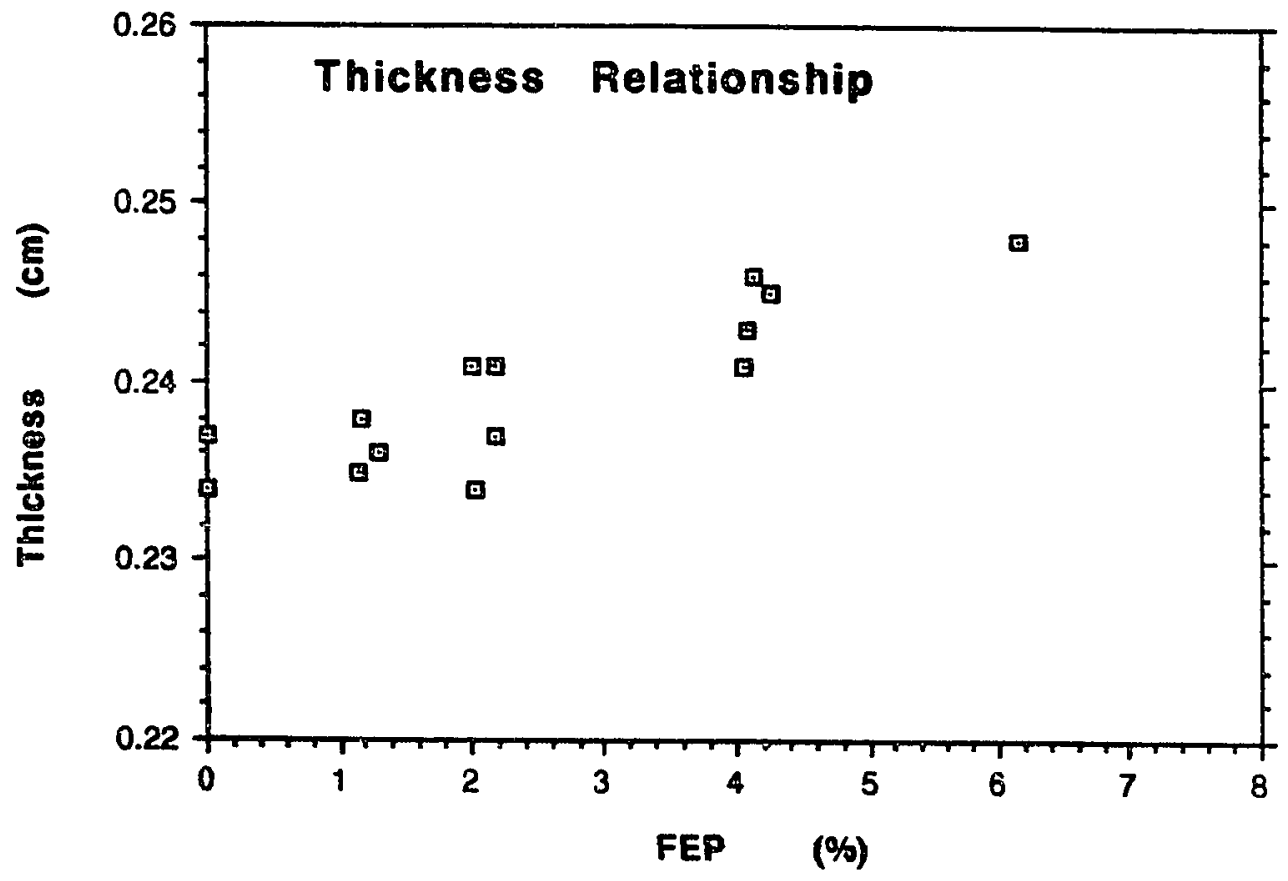

Figure 38. Post-Cure Panel Thickness as a Function of Added Tefilon. 


\subsection{Effects on the Mode of Failure}

A qualitative evaluation of the toughness can be. obtained by an examination of the 3-point bend specimens after testing. This was done and the results are shown in Figures 39, 40, 41, and 42 for the warp direction, and Figures $43,44,45$, and 46 for the fill direction.

Figure 39 shows a representative set of warp direction specimens with $0 \%$ Tefion. As shown with the stress-strain curve in Figure 21, these specimens are characterized by a brittle fracture. The fracture in these specimens is mainly a single translaminar crack that propagated to failure. The specimens shown in Figures 40, 41, and 42 are typical of samples with added Tefion, and correlate well with the stress-strain curves displaying greater toughness and damage tolerance. The fractures shown here have a greater amount of multiple cracking. 


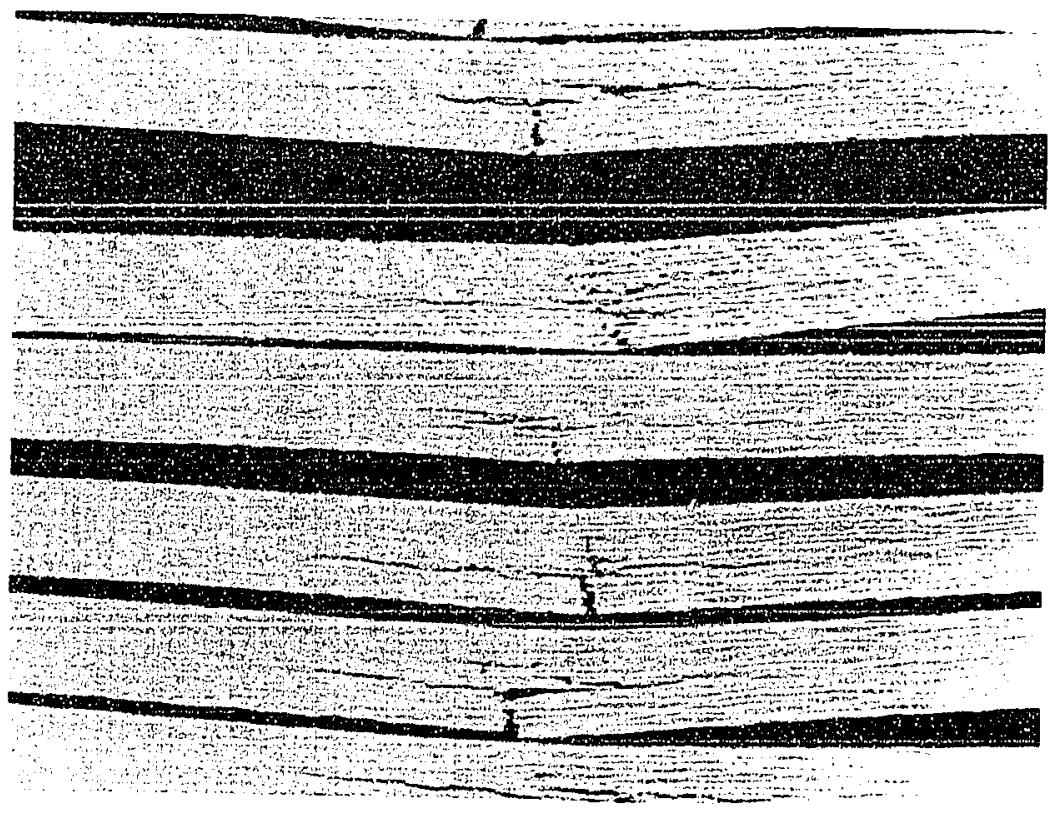

Figure 39. Three Point Bend Specimens Fracture Zone. Warp Direction, Panel E, 0\% Added Teflon.

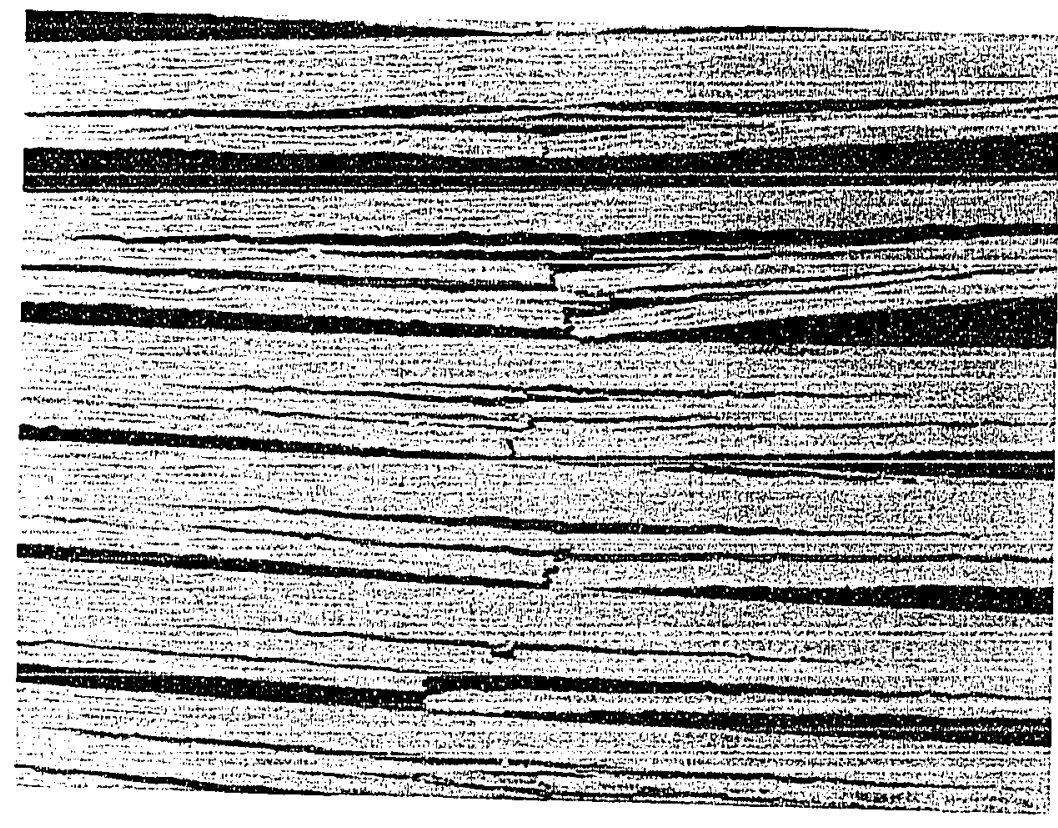

Figure 40. Three Point Bend Specimens Fracture Zone. Warp Direction, Panel F, $1.28 \%$ Added Teflon. 


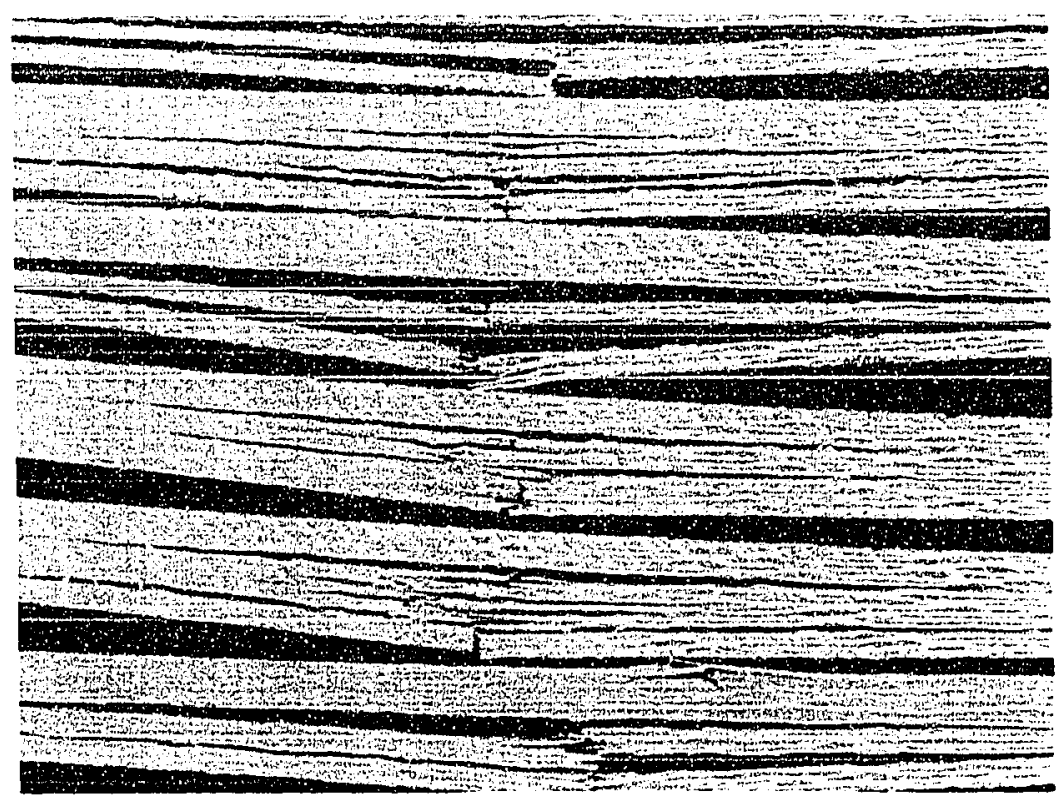

\section{Figure 41. Three Point Bend Specimens Fracture Zone. Warp Direction, Panel O, 2.02\% Added Teflon.}

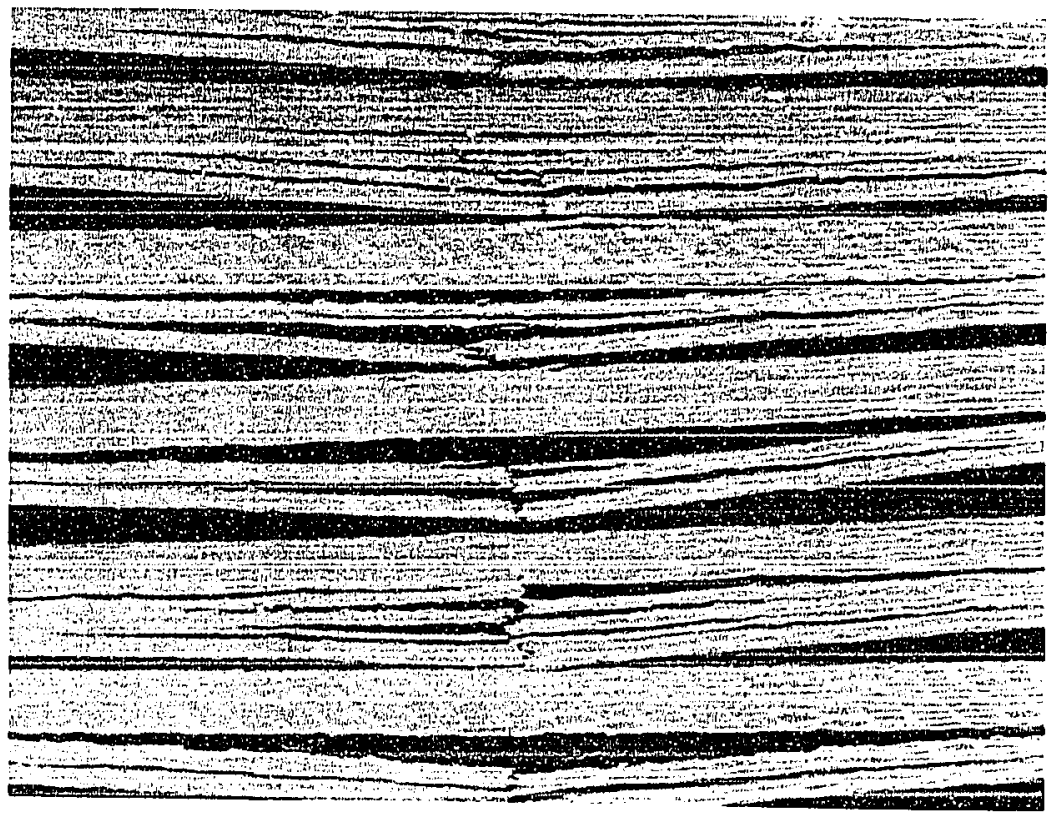

Figure 42. Three Point Bend Specimens Fracture Zone. Warp Direction, Panel $\mathrm{H}, 4.13 \%$ Added Teflon. 


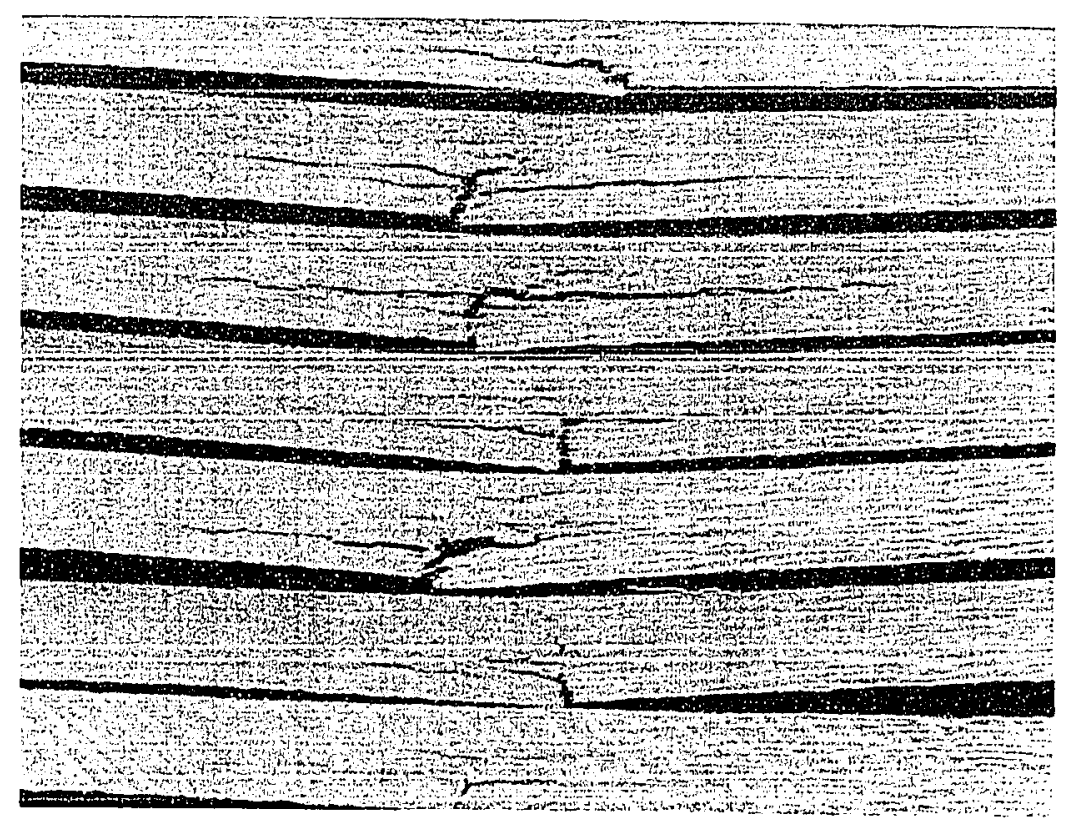

Figure 43. Three Point Bend Specimens Fracture Zone. Fill Direction, Panel $M, 0 \%$ Added Tef́lon.

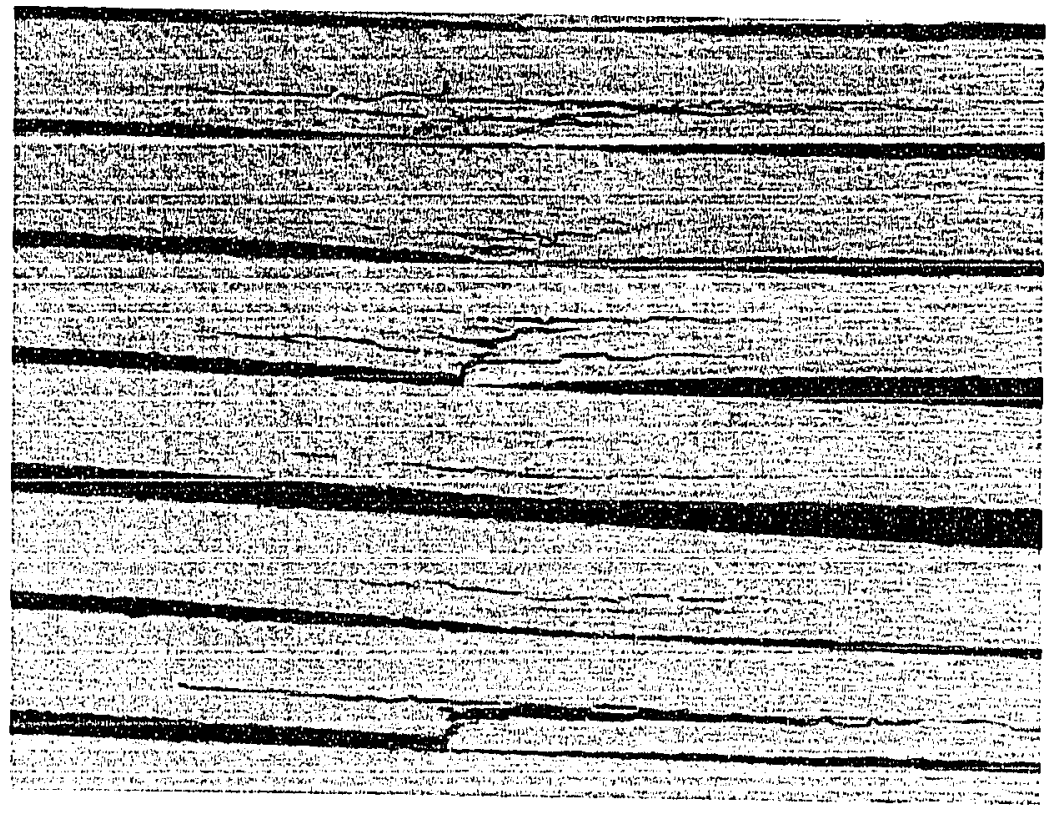

Figure 44. Three Point Bend Specimens Fracture Zone. Fill Direction, Panel N, 1.14\% Added Teflon. 


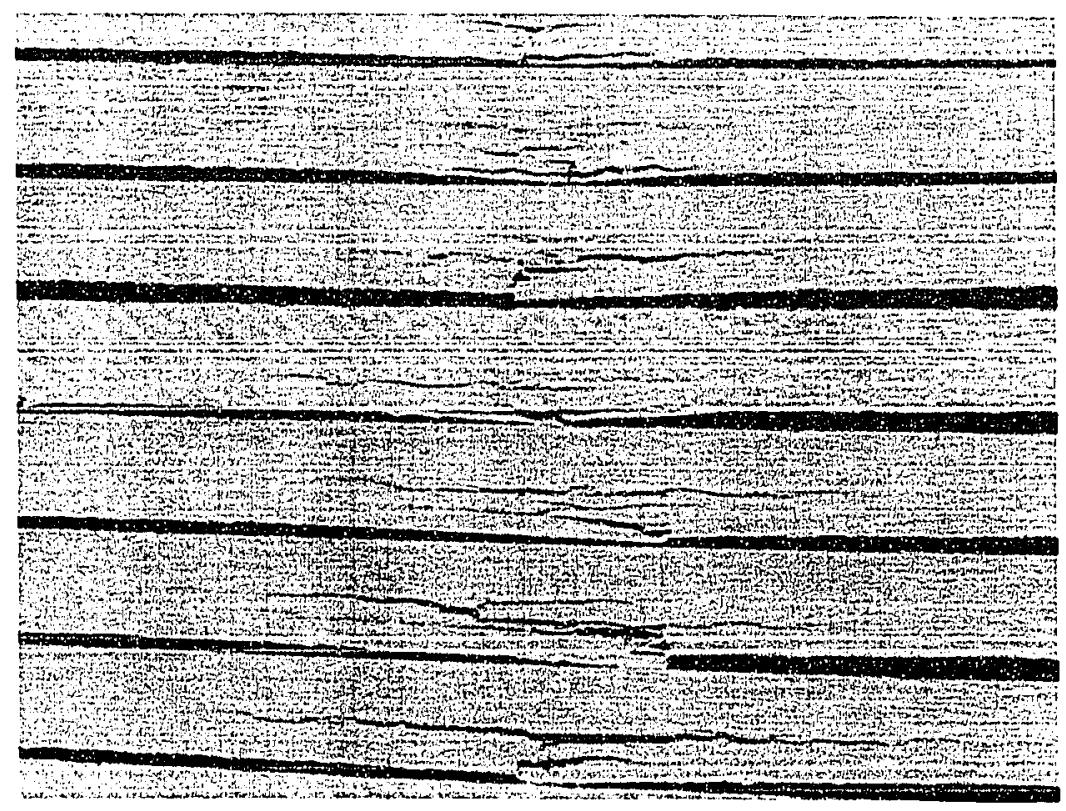

Figure 45. Three Point Bend Specimens Fracture Zone. Fill Direction, Panel G, 2.17\% Added Teflon.

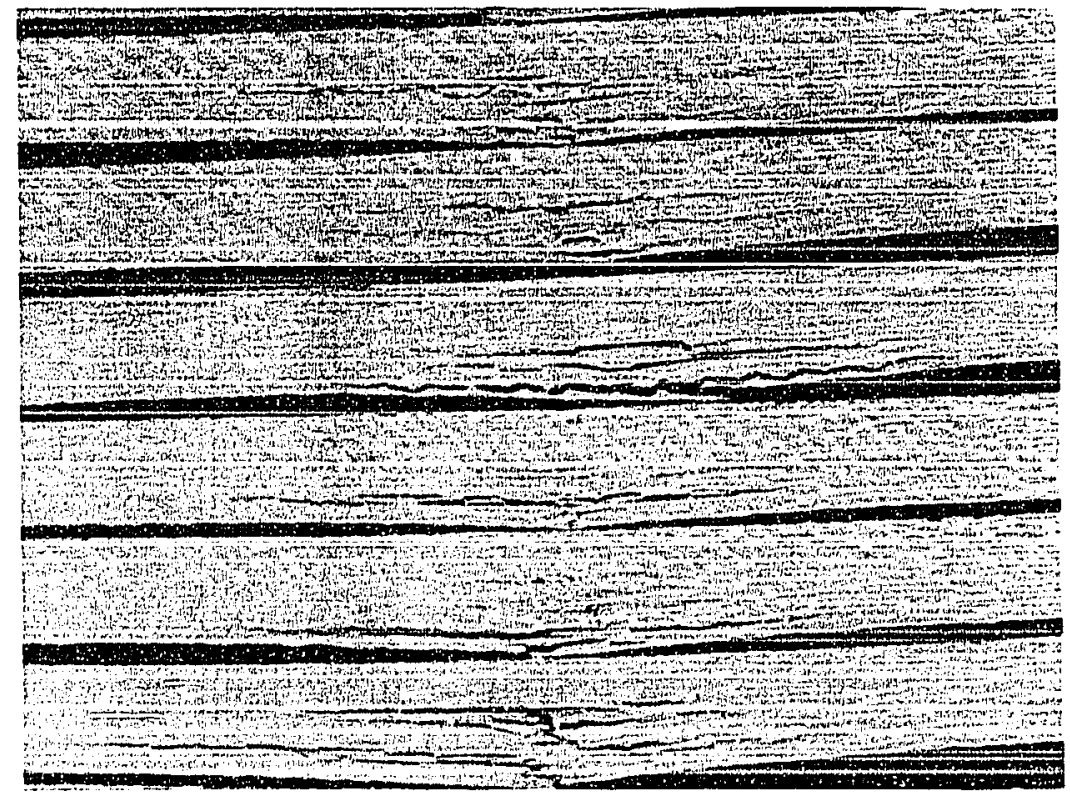

Figure 46. Three Point Bend Specimens Fracture Zone. Fill Direction, Panel D, 4.25\% Added Teflon. 
The fill direction specimens maintained a relatively low level of toughness, and damage tolerance, even with the addition of Tefion. This is shown also in the stress-strain curves of Figures 24, 25, and 26. The small amount of fracture area in these curves confirms the low level of toughness and damage tolerance. The fractures in the fill direction, even with the Tefion additions, are mainly characterized by a brittle appearance of a single dominant fracture, as shown in Figures 44,45 , and 46 . This appearance is shown in the control samples, and not much additional fracturing is evident in the test samples with Teflon. The graphs in Figures 28, and 30 , showing $\Delta \varepsilon$ and fracture energy, also confirm the lack of toughness and damage tolerance improvement in the fill direction specimens. 


\section{CHAPTER 6 \\ SUMAARY OF SIGNIFICANT RESULTS}

Some of the salient aspects in this investigation are that damage tolerance improvements, measured by strain after yield, were achieved with the addition of Teflon powder into the epoxy matrix. The improvements were seen primarily in the warp direction and the strength of the composite decreased. Since the strength decreased, the resilience and total energy of failure also decreased. The control samples had virtually no measurable strain after yield, but the test samples with Teflon additions displayed significant additional strain after yield. The additional strain is important because it increased the non-linear portion of the stressstrain curve, delaying the propagation of catastrophic cracks. Although cracking initiated at lower stress levels, and the resilience of the material decreased, the material becomes more usable in designs requiring tolerance to limited damage preceding total failure.

All specimens failed in a characteristically brittle manner. Each specimen had a relatively well behaved linear elastic region on the stress-strain curve, and ended in delamination failure of the composite. The introduction of Teñon powder changed the character of the fracture from an abrupt and complete failure, to one of a progressive and incomplete delamination of the laminae. The 
progressive delamination character is visible qualitatively in the warp direction by comparing Figure 39 with Figures 40, 41, and 42 . Fractures in the samples without Tefion additions were characterized by single, predominantly translaminar, cracks. Fractures in the test samples with Tefton had multiple fractures occurring, and the mode of failure changed to interlaminar and intralaminar. It appears that the Teflon powder was able to provide sites for crack growth, and was able to increase the surface area generated by the cracking. The effect of this is that the Tefion powder dispersed in the matrix established a non-elastic portion to the stress-strain curve. Without additions of Teflon powder, the non-elastic portion to the stress-strain curve was not present.

The damage tolerance was measured quantitatively as $\Delta \varepsilon$ and $\Delta \varepsilon \times \sigma_{b}$ on the stress strain curve for each sample. It was seen that increases in $\Delta \varepsilon$ were greater for warp direction samples, and only slight for fill direction samples. However, damage tolerance was improved even in the fill direction, because some additional strain before failure was produced. This is evident by the stress-strain curves showing multiple fracture edges at the end of the linear elastic region for these specimens. It appears that the Tefion particles, located in the matrix at a large number of sites and able to deform plastically, were able to improve damage tolerance. Cracks wers able to form at numerous sites, which provided greater strain for a given stress. Also, it appears that the Teflon was able 
to arrest some crack propagation by deforming plastically in the matrix, as is shown by the characteristic of progressive delamination. Cracks that formed at stress levels close to $\sigma_{\max }$ did not immediately propagate to failure.

Delamination strength decreased for both warp and fill directions. With a $4 \%$ addition of Teflon powder, it was shown that there was roughly a $7 \%$ loss in $\sigma_{\max }$ for the warp direction, and $13 \%$ loss in the fill direction. This is believed to be due to the dispersion of particles on a small scale not being uniform. With high concentrations of Tefion powder in localized regions of the prepreg weave pattern, delamination cracking can initiate and propagate to failure at lower stress levels. The powder was intended to act as discrete particles, generating numerous and small defects uniformly in the matrix. In a concentrated group the Tefion can act as a rolativoly large dafect. It is possible that this is responsible for the decrease in strength. The Tefion powder was able to arrest some propagation of cracks in the warp direction, but not as much in the fill direction. The reason for this effect is not clear from these tests. However, it is possible that during the manufacturing process for the prepreg material, a greater amount of fiber damage is caused in the fill direction due to the weave process. This makes the fill direction fibers more sensitive to cracking and crack propagation. 
In both the warp and fill directions the flexural modulus decreased slightly, roughly $1 \%$. This can be attributed to the fact that the Teflon additions made up only small volume percentages of the matrix, and so the loss in bond strength to the fibers was minimal. The fibers then were still the dominant contributor to the stiffness of the material, and the flexural modulus remained roughly unchanged. The flexural modulus is determined by the linear portion of the stress-strain curve, before delamination cracking begins to occur.

The relative merits of the damage tolerance improvement can be evaluated by comparing $\Delta \varepsilon$ with the elastic strain, and by comparing $\Delta \varepsilon \times \sigma_{\mathrm{b}}$ with the resilience, the elastic energy of deflection. An addition of $4 \%$ Tefion powder increased the warp direction strain from an average value of $0.013 \mathrm{~mm} / \mathrm{mm}$ to 0.016 $\mathrm{mm} / \mathrm{mm}$, which is approximately a $20 \%$ increase above the elastic strain. In the fill direction only a $4 \%$ increase above the elastic strain was achieved. Likewise, in evaluating the fracture energy, the $4 \%$ Teflon powder addition in warp direction samples showed an average increase from $4.6 \mathrm{MJ} / \mathrm{m}^{3}$ for the elastic strain energy, to $6.2 \mathrm{MJ} / \mathrm{m}^{3}$ for elastic strain energy plus delamination energy. This is an increase of $33 \%$ for the warp direction specimens. For the same conditions in the fill direction, an $11 \%$ increase in energy from $4.6 \mathrm{MJ} / \mathrm{m}^{3}$ to $5.1 \mathrm{KJ} / \mathrm{m}^{3}$ was achieved. The control samples showed no measurable non-elastic delamination energy. 
Combining the increase in delamination energy with the decrease in $\sigma_{\max }$, it was shown that the total energy of failure (the total area under the stress-strain curve) remained roughly constant for the warp direction specimens, but decreased by roughly $21 \%$ in the fill direction. This is attributed to the relatively large decrease in $\sigma_{\max }$ for the fill direction, without significantly increasing $\Delta \varepsilon$.

Adding the Tefion powder apparently did not increase the inherent defect population caused by the manufacturing process. Inherent defects, such as misalignment of plies, broken fibers, voids, or contamination, are largely responsible for variations in the test data that are observed in all test samples. The standard deviation of the average for a set of test samples frequently is a measure of the processing quality. A large value in the standard deviation implies non-uniformity and random defects in the material, which leads so scatter in the test data. It was shown in this experiment that the standard deviations for the averages of the strengths and moduli did not increase with added Tefion. This implies that the measured effects of toughness and damage tolerance were not biased by additional factors in the sample fabrication process. 


\section{CHAPTER 7}

\section{CONCLUSIONS}

This study has shown that GFRP damage tolerance, measured as additional strain atter yield, can be produced with the addition of Teflon powder into the epoxy matrix. The control samples had virtually no measurable strain after yield, but the test samples with Teflon displayed significant additional strain after yield. The additional strain is important because it increased the non-linear portion of the stress-strain curve, delaying the propagation of catastrophic cracks. Although cracking initiated at lower stress levels and the resilience of the material decreased, the material may be more usable in designs requiring tolerance to limited damage preceding total failure. Toughness, as measured by the total area under the stress-strain curve, did not increase. With the addition of the Teflon particles, the strength of the composite decreased. The decrease in strength was greatest in the fill direction, and when combined with the small increase in strain before failure, the fill direction showed a decrease in the total energy of failure.

The test specimens showed qualitatively that by the addition of Teflon particles in the matrix, there is a greater degree of multiple iracturing in the material under load. The visual appearance of the ractures correlated with the measured values of additional strain, showing that the additional strain is due to 
progressive delamination of the material without total failure. Fractures in the samples without Teflon were characterized by single, predominantly translaminar cracks. Test samples with Teflon had multiple fractures, and the mode of failure changed to interlaminar and intralaminar. It appears that the Teflon powder was able to provide sites for crack growth, and was able to increase the surface area generated by the cracking.

Test specimens in both the warp and fill directions showed only a slight decrease in flexural modulus. The quantity of Tefion used in this experiment was sufficiently small so that the loss in bond strength to the fibers was minimal, and the fibers still dominated the stiffness properties. Even though the strength of the composite decreased, and delamination cracking was initiated at lower stress levels, the modulus is measured in the linear elastic region of the stress-strain curve, before delamination fracturing begins to occur.

Adding the Teflon powder did not increase the inherent defect population caused by the sample fabrication process. A measure of the processing quality is the value of the standard deviation of the average of the test samples. For both the warp and fill directions, the standard deviations did not increase with added Tefion. This implies that the measured effects in toughness and damage 
tolerance were not biased by additional factors in the sample fabrication process.

It appears that the effectiveness of the Teflon was limited by the degree of uniformity in the distribution of the particles in the composite. The decrease in strength accompanying the improvement in strain to failure is most likely attributed to the Toflon not being dispersed uniformly on a small scale. Using Teflon powder appears to be a viable method for improving damage tolerance and toughness by introducing a large number of small and ductile defects.

However, future studies should improve on the method of dispersing the particles. Future studies may examine processes for adding the particles directly to the epoxy prior to the prepreg stage. If this can be done, it will ensure dispersion not subjected to the geometry of the fibers in the weave pattern.

This project also was not able to distribute defects directly onto the fibers. Application of the particles after the prepreg stage did not assure defects would be located directly at the interface. The literature survey showed that additional toughness may be achieved by small defects at the fiber-matrix interface. The defects may generate localized yielding on fibers under load and that would increase the strain to failure. Future studies may examine processes for locating the defects at the fiber-matrix interface. 
These processes may include adding defects to the sizing material as applied to the fibers.

A related project would be to increase the level of adding Tetion to the matrix above $6 \%$. This project produced only one panel at $6 \%$, and it is possible that additional improvements can be realized at higher levels. At higher levels of Teflon in the matrix, the loading eventually will be large enough to decrease strength and flexural modulus beyond acceptable levels. It is not clear from these tests that $6 \%$ is the maximum level for achieving acceptable results, and higher levels may be tried, especially if the uniformity of the distribution is improved.

Additional studies to continue this investigation should include separating and examining the fracture surfaces under high magnification. This may reveal more information about the crack propagation processes that were affected by the Tefion particles. Also, a highly magnified view of a section of the mairix may show is the distribution of particles is uniform after cure. The resin flows during the cure process, and it is not known what effect that has on the particle distribution. This investigation showed a significant difference in the results in the warp direction compared to the fill direction samples. The exact reason for this effect was not apparent from these tests. From micrographs that were taken, it was proposed that the effect was due to accumulation of Teflon 
powder against the fill direction fibers. The accumulation was due to the weave pattern on the warp face up fabric, which was the orientation when the powder was applied. This could be verified by repeating the experiment and applying the powder to the fill face up. In that case the weave pattern would be reversed, and then the powder would accumulate against the warp direction fibers. A reversal of the directional effects seen in this project would confirm the importance of the uniform distribution of powder on a scale smaller than the weave pattern. 


\section{REFERENCES}

1. ASM Engineered Materials Handbook, Vol. 1, Composites, ASM International, 1987, pp. 49-53.

2. ASM Engineered Materials Handbook, Vol. 1, Composites, ASM International, 1987, pp. 817.

3. Agarwal, Bhagwan D., and Broutman, Lawrence J., Analysis and Performance of Fiber Composites, John Wiley and Sons, 1980, pp. 257-258.

4. ASM Engineered Materials Handbook, Vol. 1, Composites, ASM International, 1987, pp. 786-793.

5. Friedrich, K., "Microstructural Efficiency and Fracture Toughness of Short/Fiber Thermoplastic Matrix Composites", Composites Science and Technology 22, (1985), pp.43-74.

6. Cairns, Douglas S., "Toughening Mechanisms in Multi-Phase Media", 34th International SAMPE Symposium, (May 8-11, 1989), pp. 2081-2095 
7. Masters, John E., "Structural Performance and Impact Resistance of Advanced Interleafed Materials", 34th International SAMPE Symposium, (May 8-11, 1989), pp. 17921802.

8. Sela, N., and ishai, O., "Interlaminar Fraciure Toughness and Toughening of Laminated Composite Materials: A Review", Composites, Vol. 20, No. 5, (Sept. 1989), pp. 423-435.

9. Pottick, L. A., "Kraton Rubber Modified Epoxy Blends", 34th International SAMPE Symposium, (May 8-11, 1989), pp. 22432254.

10. Thorfinnson, Bradley S., and Folds, Thomas J., "Method of Increasing the Toughness of Fiber-Reinforced Composites Without Loss of Modulus", United States Patent, Patent Number 4,778,716, (Oct. 18, 1988).

11. Saghizadeh, H., and Dharan, C. K. H., "Delamination Fracture Toughness of Graphite and Aramid Epoxy Composites", Transactions of the ASME, Vol. 108, (Oct. 1986), pp. 290-295.

12. Piggott, M.R., and Reboredo, M.M., "The Properties of the Interface Between Fibres and Polymers", 34th International SAMAPE Symposium, (May 8-11, 1989), pp. 1913-1923. 
13. Friedrich, Klaus, Fracture Mechanical Behavior of Short Fiber Reinforced Thermoplastics, Reihe 18: Bruchvorgange und, Schadensanalyse, (1984), pp. 89-96.

14. "Flexural Properties of Unreinforced and Reinforced Plastics and Electrical Insulating Materials, Standard Test Methods for", ASTM D 790-91, American Society for Testing and Materials, (1991).

15. Agarwal, Bhagwan D., and Broutman, Lawrence J., Analysis and Performance of Fiber Composites, John Wiley and Sons, 1980. pp. 262-263.

16. Carlsson, Leif A., and Pipes, R. Byron, Experimental Characterization of Advanced Comoosite Materials, PrenticeHall, Inc., (1987), pp. 85-90. 


\section{BIBLIOGRAPHY}

1. Barsom, John M., and Rolfe, Stanley T., Fracture and Fatique Control in Structures: Applications of Fracture Mechanics, 2nd Edition, Prentice Hall, Inc., 1987.

2. Collins, J.A., Failure of Materials in Mechanical Design: Analysis, Prediction. Prevention, John Wiley and Sons, 1981.

3. Hertzberg, Richard W., Deformation and Fracture Mechanics of Engineering Materials, 3rd Edition, John Wiley and Sons, 1976.

4. Hogg, Robert V., and Ledolter, Johannes, Engineering Statistics, Macmillan Publishing Co., 1987.

5. Jones, Robert M., Mechanics of Composite Materials, McGrawHill Book Co., 1975.

6. Tsai, S.W., and Hahn, H.T., iniroduction to Composite Matorials, Technomic Publishing, 1980. 


\title{
APPENDIX A: INSTRUMENTED MECHANICAL TEST DATA FOR ALL SPECIMENS
}

\author{
LOCXFED MISSILES \& SHACE CO. \\ MATERIFLS : FROCESSES ETGINEIRING \\ DarT. $76-30$
}

3 Foint Compressive Test-S.1. Units. Ram Data

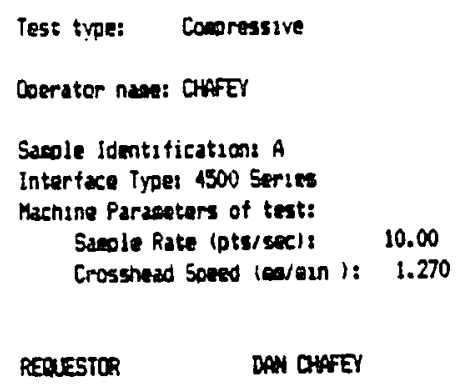

Dicensions:

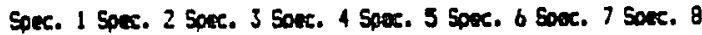

\begin{tabular}{|c|c|c|c|c|c|c|c|c|}
\hline (ata) & 12.700 & 12.700 & 12.700 & 12.700 & 12.700 & 12.700 & 12.700 & 12.700 \\
\hline Threxness (en) & 2.5700 & 2.5700 & 2.3700 & 2.5700 & 2.5700 & 2.5700 & 2.3700 & 2.37 \\
\hline Spec gaupe im & 30.800 & 50.800 & 50.800 & 50.800 & 50.800 & 50.800 & 50.800 & 50.8 \\
\hline (m) & 101.60 & 101.00 & 101.60 & 101.60 & 101.60 & 101.60 & 101.60 & 1 \\
\hline
\end{tabular}

aut of 10 soeciens, 0 exclued.

\begin{tabular}{|c|c|c|c|c|c|c|c|c|c|c|}
\hline $\begin{array}{l}\text { Soecicen } \\
\text { Number }\end{array}$ & ID: & $\begin{array}{c}\text { Disolesent } \\
\text { at } \\
\text { Mx.Loud } \\
\text { (m) }\end{array}$ & $\begin{array}{l}\text { Load } \\
\text { at } \\
\text { Max.Load } \\
\text { (KN) }\end{array}$ & $\begin{array}{c}\text { Stress } \\
\text { at } \\
\text { Max.LaAd } \\
\text { (iPa) }\end{array}$ & $\begin{array}{l}\text { moctuluss } \\
\text { (Putroung) } \\
\text { (IPa) }\end{array}$ & $\begin{array}{l}\text { Stress } \\
\text { at offest } \\
\text { Yiald I } \\
\text { (na) }\end{array}$ & $\begin{array}{l}\text { Strain } \\
\text { at offeset } \\
\text { yield } 1 \\
\text { (exeal }\end{array}$ & $\begin{array}{l}\text { Stress } \\
\text { at user } \\
\text { Breat } \\
\text { (IPa) }\end{array}$ & $\begin{array}{c}\text { Strain } \\
\text { at user } \\
\text { Break } \\
\text { (now) }\end{array}$ & $\begin{array}{c}\text { Load } \\
\text { at user } \\
\text { Break } \\
\text { (WN) }\end{array}$ \\
\hline 1 & Aal & 2.996 & .7113 & 753.6 & elswo. & $713 . \infty 0$ & .0162 & 713.6 & .0102 & .6735 \\
\hline 2 & A.2 2 & 2.921 & .7238 & 771.5 & E3100. & 17.12 & .0163 & 769.9 & .0163 & .7260 \\
\hline 3 & $\mathrm{As}_{3}$ & 2.870 & . 7113 & 753.6 & 83180. & 36.68 & .0180 & $\pi 1.7$ & .0159 & .7055 \\
\hline 4 & 423 & 2.921 & .7344 & $\pi 78.1$ & 02560. & 667.90 & .0162 & 667.9 & .0162 & . äit \\
\hline 5 & A.S & 3.175 & .0050 & 605.5 & 88910. & 19.16 & .0177 & 852.3 & .0177 & .8044 \\
\hline 0 & $A=s$ & 2.946 & .7451 & $799: 4$ & 83210. & 19,47 & .0165 & 787.5 & .0164 & .7432 \\
\hline 7 & A 07 & 3.277 & .85800 & 897.9 & BAS90. & 22.79 & .0183 & 897.0 & .0182 & .8371 \\
\hline 8 & $A \times B$ & 3.023 & $.7 \pi 2$ & 818.2 & 84860 . & 24.75 & .0169 & 816.0 & .0169 & .7701 \\
\hline 9 & 188 & 2.870 & .734 & $\pi 8.1$ & 65830. & 44.81 & .0161 & $m .2$ & .0160 & . ग55 \\
\hline 10 & & 2.862 & .7230 & $\pi 0.3$ & 86130. & 651.80 & .0260 & 651.8 & .0160 & .6152 \\
\hline fen: & & 2.976 & .7307 & 795.4 & 23890 . & 221.80 & o160 & 767.5 & .0160 & .2244 \\
\hline $\begin{array}{l}\text { Standard } \\
\text { Laviation: }\end{array}$ & & .142 & .0120 & 44.5 & 1454. & 315.10 & .0060 & 75.1 & .0000 & .0709 \\
\hline Minian: & & 2.862 & .7113 & 735.6 & 81500. & 17.12 & .0160 & 651.8 & .0159 & .0152 \\
\hline Maxinus: & & 3.277 & .8380 & 897.9 & $\$ 130$. & 713.60 & .0183 & 887.0 & .0182 & .6351 \\
\hline
\end{tabular}




\title{
APPENDIX A: INSTRUMENTED MECHANICAL TEST DATA FOR ALL SPECIMENS \\ (continued)
}

\author{
LOOKEED MISSILES \& TPACE CO. \\ MATERIALS \& PROCESESS DEIHEEING \\ DEPT. $78-30$ \\ I Foint Coosressive Test-S.1. Lnits, Res Data
}

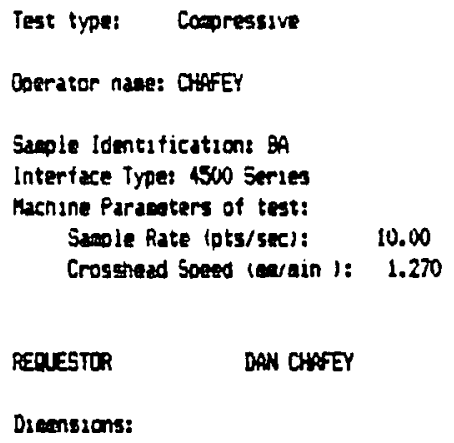

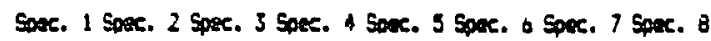

$\begin{array}{llllllll}12.700 & 12.700 & 12.700 & 12.700 & 12.700 & 12.700 & 12.700 & 12.700\end{array}$

$\begin{array}{llllllll}2.4100 & 2.4100 & 2.4100 & 2.4100 & 2.4100 & 2.4100 & 2.4100 & 2.4100\end{array}$

$\begin{array}{llllllllllll}50.600 & 50.800 & 50.800 & 50.800 & 50.800 & 50.800 & 50.800 & 50.800\end{array}$

$\begin{array}{lllllllll}101.60 & 101.60 & 101.00 & 101.00 & 101.60 & 101.60 & 101.00 & 101.00\end{array}$

Out of 10 soecrems. 0 excluded.

\begin{tabular}{|c|c|c|c|c|c|c|c|c|c|c|}
\hline $\begin{array}{l}\text { Soesianen } \\
\text { Humerer }\end{array}$ & ID: & $\begin{array}{c}\text { Displceent } \\
\text { at } \\
\text { Max.Land } \\
\text { (m) }\end{array}$ & $\begin{array}{l}\text { Load } \\
\text { at } \\
\text { Max.Loxd } \\
\text { (XaA) }\end{array}$ & $\begin{array}{c}\text { Stress } \\
\text { at } \\
\text { Max.Lond } \\
(\text { (IPPa) }\end{array}$ & $\begin{array}{l}\text { Modulus } \\
\text { (Autroung) } \\
\text { (tral) }\end{array}$ & $\begin{array}{l}\text { Stress } \\
\text { at otfant } \\
\text { Yisld } 1 \\
\text { (FPa) }\end{array}$ & $\begin{array}{l}\text { Strain } \\
\text { at offest } \\
\text { Vield } 1 \\
\text { (magas) }\end{array}$ & $\begin{array}{l}\text { Stress } \\
\text { at user } \\
\text { Break } \\
\text { (Foa) }\end{array}$ & $\begin{array}{c}\text { Strain } \\
\text { at usar } \\
\text { Break } \\
\text { (Eajea) }\end{array}$ & $\begin{array}{l}\text { Loso } \\
\text { as user } \\
\text { Brtak } \\
\text { (WA) }\end{array}$ \\
\hline 1 & BAI & 3.048 & .7202 & 750.4 & 79870. & 55.1 & .0116 & 749.2 & .0167 & .7190 \\
\hline 2 & EA & 2.067 & $.06 \pi / 6$ & 650.2 & 81500. & 453.8 & $.015 \overline{80}$ & เ57. & .0851 & 2 \\
\hline 3 & BAS & 2.718 & .7042 & 738.7 & 02990. & 597.9 & .012 & 710.9 & .0151 & . \\
\hline 4 & BAA & 3.175 & .8220 & 856.5 & 83820. & 847.9 & .0175 & 760.8 & .0176 & .7302 \\
\hline 5 & BAS & 3.046 & .7945 & 827.8 & 84010. & 141.1 & .0170 & 027.4 & .0170 & .7940 \\
\hline 6 & $B A B$ & $2.97 /$ & .7540 & 780.6 & 83490. & 749.2 & .0158 & 784.8 & .0165 & .7532 \\
\hline 7 & BA7 & 2.743 & .7069 & 736.5 & B3210. & 707.3 & .0153 & 730.3 & .0159 & .7059 \\
\hline 8 & BAB & 2.819 & .7293 & 760.1 & 83260 . & 709.5 & .0148 & 693.6 & .0164 & .0657 \\
\hline 9 & $B A$ & 2.845 & .659 & 681.3 & 83500 . & 636.5 & .0133 & 678.1 & .0159 & .0508 \\
\hline 10 & Hio & 2.946 & .7008 & 757.9 & 83000. & 656.1 & .0136 & 648.1 & .0167 & .0220 \\
\hline Men: & & 2.898 & .7200 & 750.5 & 82870. & 62.4 & .0145 & 724.8 & .0103 & .6950 \\
\hline Stanoard & & & & & & & & & • & \\
\hline Devilation: & & .160 & .052 & 31.4 & 1205. & 199.9 & .0019 & 57.2 & .0008 & .05511 \\
\hline Minten: & & 2.657 & .6539 & 681.3 & 79870. & 141.1 & .0116 & 49.1 & .0151 & .0220 \\
\hline Maximan: & & S.179 & .8220 & 86.5 & s4cio. & 847.9 & .0175 & 827.4 & $.017 \%$ & .8940 \\
\hline
\end{tabular}




\title{
APPENDIX A: INSTRUMENTED HECHANICAL TEST DATA FOR ALL SPECIMENS

\author{
(continued)
}

\author{
LOCKAEED MISSILES \& SPACE CO. \\ HATERIALS \& PROCESSES ENGIHERRING \\ DFT. $70-30$ \\ 3 Point Conoressive Test-S. i. Lits, Fian lata
}

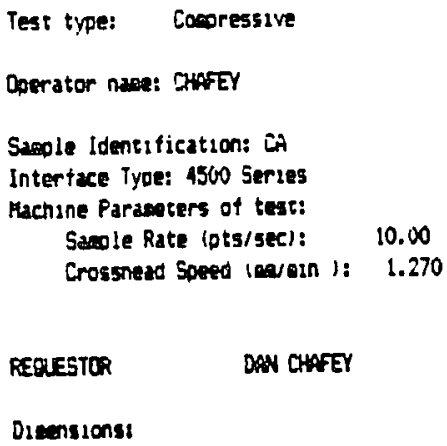

Dut of 10 specisens. 0 excluded.

\begin{tabular}{|c|c|c|c|c|c|c|c|c|c|c|}
\hline $\begin{array}{l}\text { Soeciem } \\
\text { mumoer }\end{array}$ & ID: & $\begin{array}{c}\text { Disol caent } \\
\text { at } \\
\text { hax.Loxd } \\
\text { (an) }\end{array}$ & $\begin{array}{l}\text { Load } \\
\text { at } \\
\text { Max.Lond } \\
\text { (KN) }\end{array}$ & $\begin{array}{l}\text { Stress } \\
\text { at } \\
\text { Max.Load } \\
\text { (trea) }\end{array}$ & $\begin{array}{l}\text { mooulus } \\
\text { (Putroung) } \\
\text { (RPa) }\end{array}$ & $\begin{array}{l}\text { Stress } \\
\text { at offset } \\
\text { Yield I } \\
\text { (MiPa) }\end{array}$ & $\begin{array}{l}\text { Strain } \\
\text { at oftest } \\
\text { Yield 1 } \\
\text { (eareal }\end{array}$ & $\begin{array}{l}\text { Stress } \\
\text { at usser } \\
\text { Break } \\
\text { (IPa) }\end{array}$ & $\begin{array}{c}\text { Strain } \\
\text { at user } \\
\text { Break } \\
\text { (Ea/m) }\end{array}$ & $\begin{array}{l}\text { Load } \\
\text { at user } \\
\text { Brear } \\
\text { (r) }\end{array}$ \\
\hline 1 & CAI & 2.997 & $.72 \pi$ & 767.8 & 81500. & 741.40 & .0162 & 760.8 & .0167 & $. \overline{1}+\infty$ \\
\hline 2 & CA2 & 2.972 & .7595 & 780.0 & 81590. & 744.20 & . Otab & 744.2 & .0166 & .7054 \\
\hline 3 & $\operatorname{CAS}$ & 2.896 & .7277 & 767.8 & 23290. & 105.10 & .0161 & 766.5 & .0161 & .7205 \\
\hline 4 & $\mathrm{CAA}$ & 2.972 & .7415 & 782.4 & 82130 & 765.20 & .0162 & 78.2 & .0166 & .7414 \\
\hline 5 & CAS & 3.099 & .7651 & 807.2 & 85290. & 742.60 & .0156 & 805.3 & .0173 & $.763:$ \\
\hline 6 & CAS & 2.769 & .7024 & 741.1 & 86900. & 734.20 & .0154 & 740.0 & .0155 & .7013 \\
\hline 7 & $\mathrm{CA} 7$ & 2.870 & .7197 & 759.4 & 81370. & 730.50 & .0154 & 730.4 & .0164 & .7113 \\
\hline 8 & CAR & 3.048 & .7664 & 808.6 & 81730. & 787.20 & .0166 & 807.3 & .0170 & .7652 \\
\hline 9 & $\mathrm{CAO}$ & 2.819 & .7064 & 745.3 & 82540. & 98.74 & .0157 & 743.5 & .0157 & .7047 \\
\hline 10 & CA1O & 2.972 & .7424 & 780.3 & 02150. & 770.70 & .0163 & 781.6 & .0160 & .7400 \\
\hline Maan: & & 2.941 & .7539 & $\pi 4.3$ & 02800. & 622.00 & .0160 & 768.8 & .0164 & $\therefore 280$ \\
\hline $\begin{array}{l}\text { Stanoard } \\
\text { Deviation: }\end{array}$ & & .102 & .0216 & 22.8 & 725. & 274.70 & .0005 & 24.9 & .00066 & .020 \\
\hline ทั1กเeนa: & & 2.769 & .7024 & 741.1 & 81370. & 98.74 & .0154 & 740.0 & .0155 & .7012 \\
\hline Ma:1oun: & & 3.099 & .7664 & 800.6 & 83290. & 787.20 & . & 807.3 & .0175 & .7652 \\
\hline
\end{tabular}




\title{
APPENDIX A: INSTRUMENTED MECHANICAL TEST DATA FOR ALL SPECIMENS
}

\section{(continued)}

\author{
LOCKHEED MISSILES \& SPACE CO. \\ MATERIALS \& FROCESSEE ENGINEENING \\ DEPT. 7Q-30
}

j Fo:nt Compressive iest-S. I. Units, Ras Data

Test type: Comoressive

Ooerator nase: CHafer

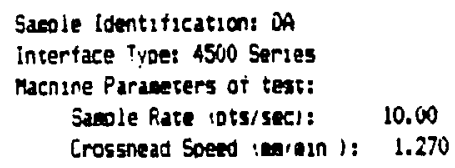

Instron Laroration

Series IX intoested Materials Testina jrstea 1.:88 Test bare: if Feo 1993

Sweole Type: ASTM

keasdity 1 6 i: 50 Temorature ideg. Fi: 13

REQUESTCR DAN CHAFEY

Diaensions:

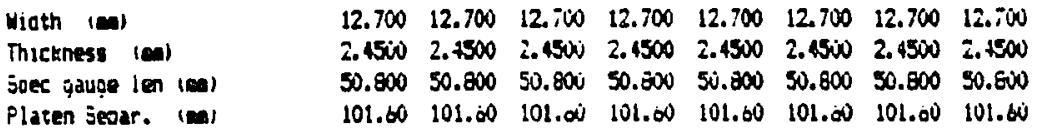

Out of liv soes:mens. O excluded.

\begin{tabular}{|c|c|c|c|c|c|c|c|c|c|c|}
\hline $\begin{array}{l}\text { Eoeciaen } \\
\text { thumer }\end{array}$ & ID: & $\begin{array}{l}\text { Disoleasnt } \\
\text { at } \\
\text { thax.Ladd } \\
\text { tee }\end{array}$ & $\begin{array}{l}\text { Load } \\
\text { at } \\
\text { hax.Load } \\
\text { (IN) }\end{array}$ & $\begin{array}{l}\text { Streas } \\
\text { at } \\
\text { Max.Louo } \\
(1 \mathrm{~Pa})\end{array}$ & $\begin{array}{l}\text { (Autroung) } \\
\text { (ifa) }\end{array}$ & $\begin{array}{l}\text { Stress } \\
\text { at oftses } \\
\text { rald I } \\
\text { (ripal }\end{array}$ & $\begin{array}{l}\text { Strain } \\
\text { at oftest } \\
\text { rield I } \\
\text { (mas }\end{array}$ & $\begin{array}{l}\text { Stress } \\
\text { at user } \\
\text { Breda } \\
\text { (tPa) }\end{array}$ & $\begin{array}{l}\text { Strain } \\
\text { at user } \\
\text { Break } \\
\text { inas oes }\end{array}$ & $\begin{array}{l}\text { Laad } \\
\text { af user } \\
\text { greak } \\
\text { (KN) }\end{array}$ \\
\hline 1 & DAI & 2.540 & .6372 & 655.2 & 81700. & 601.9 & .0142 & 601.9 & .0142 & $.58 \%$ \\
\hline 2 & $\mathrm{DA2}$ & 2.438 & .6147 & 630.1 & 81740. & 609.2 & .0130 & 699.0 & .0136 & .0157 \\
\hline 3 & [A] & 2.458 & .6272 & 642.8 & BlBiv. & $3 \pi \cdot 4$ & .0121 & 636.; & .0137 & .6212 \\
\hline 4 & DA & 2.667 & .6472 & 663.4 & ex400. & 576.0 & .0123 & 662.9 & .0149 & .6467 \\
\hline 5 & DAS & 2.042 & .6388 & 654.7 & Givo. & 558.7 & $.01: 0$ & 551.2 & .0170 & .5576 \\
\hline$\dot{0}$ & $D A 6$ & 2.946 & .7286 & 746.8 & $\cos x$. & 572.1 & .0121 & 726.7 & .0167 & .7090 \\
\hline 7 & DA97 & 2.692 & . & 697.1 & $021 \%$ & 578.4 & .0123 & 634.3 & .0151 & .0189 \\
\hline 8 & 098 & 2.743 & .6797 & 696.6 & ह0.0. & 619.1 & . vil 132 & 695.7 & .0152 & .0798 \\
\hline 9 & $9 A 9$ & 2.505 & $. \infty 1:$ & 622.3 & Qupou. & 530.4 & .0114 & 500.7 & .0147 & .4944 \\
\hline 10 & $0 A 10$ & 2.540 & .5849 & 999.5 & 79650. & 534.3 & .0110 & 479.8 & .0160 & $.468 \overline{2}$ \\
\hline Mean: & & 2.6 .1 & .6448 & 600.9 & 31000. & 574.7 & .0124 & 612.5 & .0151 & .5970 \\
\hline \multicolumn{11}{|l|}{ Standary } \\
\hline Se/1at:sn: & & .153 & .0419 & 42.9 & 879. & $29 . i$ & .0008 & 79.2 & .0012 & .0775 \\
\hline Minıaus: & & 3.428 & .5849 & 599.5 & 79050. & 530.0 & .0114 & 479.8 & .0136 & $.408:$ \\
\hline 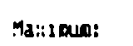 & & $2.940^{\circ}$ & 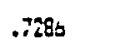 & 746.3 & $\cos$ is. & 019.1 & .0142 & 26.7 & .0170 & .709\% \\
\hline
\end{tabular}




\title{
APPENDIX A: INSTRUMENTED MECHAAICAL \\ TEST DATA FOR ALL SPECIAENS \\ (continued)
}

\author{
WONEED MISSILES \& SPACE CO. \\ HATEIALS \& PRCCESSES ENGINEEING \\ DEPT. $78-30$ \\ 3 Foint Comoressive Test-5. I. Lhits, Ran Data
}

Test type: Coesressive

Cperator nase: CHAFEY

Sacole Identification: EA

Interiace Type: 4500 Series

Machine faraseters of test:

Sample Rate lots/secl: $\quad 10.00$

Crossnead Sosed lenuain ): 1.270

REDESTRR DAN CHEFEI

Dimensions:

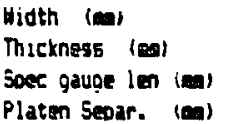

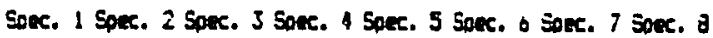

$\begin{array}{llllllll}12.700 & 12.700 & 12.700 & 12.700 & 12.700 & 12.700 & 12.700 & 12.700\end{array}$

$\begin{array}{llllllll}2.3400 & 2.3400 & 2.3400 & 2.34100 & 2.3400 & 2.3400 & 2.3400 & 2.3400\end{array}$

$\begin{array}{llllllllll}50.800 & 50.800 & 50.600 & 50.800 & 50.800 & 50.800 & 50.800 & 50.800\end{array}$

$\begin{array}{llllllll}101.60 & 101.60 & 101.60 & 101.00 & 101.60 & 101.60 & 101.00 & 101.60\end{array}$

Out of 10 soeciaens, 0 excluoed.

\begin{tabular}{|c|c|c|c|c|c|c|c|c|c|c|}
\hline $\begin{array}{l}\text { Soeciaen } \\
\text { mumber }\end{array}$ & D: & $\begin{array}{l}\text { Disolcsent } \\
\text { at } \\
\text { hax.Loud } \\
\text { (ea) }\end{array}$ & $\begin{array}{l}\text { Lasa } \\
\text { at } \\
\text { Max.Lasd } \\
\text { (KN) }\end{array}$ & $\begin{array}{c}\text { Strese } \\
\text { at } \\
\text { hax.Load } \\
\text { (Fia) }\end{array}$ & $\begin{array}{l}\text { Moculus } \\
\text { (Autroung) } \\
\text { (Fa) }\end{array}$ & $\begin{array}{l}\text { Streas } \\
\text { at oftest } \\
\text { vieid } 1 \\
\text { (Mal) }\end{array}$ & $\begin{array}{l}\text { Stramn } \\
\text { at offest } \\
\text { rield I } \\
\text { (coucos }\end{array}$ & $\begin{array}{l}\text { Stress } \\
\text { at user } \\
\text { Break } \\
\text { (fra) }\end{array}$ & $\begin{array}{c}\text { Stran } \\
\text { at user } \\
\text { Break } \\
\text { temion }\end{array}$ & $\begin{array}{l}\text { Ledo } \\
\text { at user } \\
\text { Breat } \\
\text { (KM) }\end{array}$ \\
\hline 1 & EAI & 3.073 & .7335 & 787.1 & 79700. & 27.55 & .0172 & 784.0 & .0171 & .305 \\
\hline 2 & EA2 & 2.718 & .6566 & 704.6 & 61420. & 17.42 & .0152 & 701.4 & .0152 & .0530 \\
\hline 3 & EAB & 2.845 & .6890 & 739.4 & 82360 & 15.59 & .0158 & $T 38.0$ & .0158 & . \\
\hline 4 & EA4 & 2.743 & .6550 & 700.7 & 82200 . & 74.78 & .0153 & 098.4 & $.015 \bar{z}$ & .6508 \\
\hline 5 & Eis & 2.896 & .6946 & 745.0 & 61750. & 10.53 & .0161 & 742.9 & .0161 & $.09: 2$ \\
\hline 6 & EAd & 3.073 & .7384 & 792.4 & 01570. & 28.17 & .0171 & 792.2 & .0171 & .7583 \\
\hline 7 & EA7 & 3.048 & .7384 & 792.4 & 81900. & 12.69 & .0170 & 791.4 & .0170 & 沙 \\
\hline 8 & $E A 9$ & 2.769 & .6659 & 714.6 & 81990. & 38.89 & .0153 & 712.3 & .0154 & $.00 \%$ \\
\hline 9 & BA9 & 2.318 & .6491 & 695.5 & 82130. & 68.60 & .0152 & 695.0 & .0152 & .040 : \\
\hline \multirow[t]{2}{*}{10} & EA1O & 3.073 & $.74 \pi$ & 797.6 & 82140 . & 15.51 & .0172 & 795.4 & .0171 & .7412 \\
\hline & & & & & & & & & & · \\
\hline lean: & & 2.896 & .6961 & 747.0 & 81720. & 31.28 & .0162 & 745.2 & .0161 & .094 \\
\hline \multicolumn{11}{|l|}{ jtandard } \\
\hline leviation: & & .157 & .039 & 42.2 & 760. & 22.73 & .0019 & 42.3 & 5005 & .0744 \\
\hline İกI & & 2.718 & .0481 & 695.5 & 79700. & 12.69 & .0152 & 695.6 & .0152 & .0482 \\
\hline Laxiana: & & 5.073 & كנ.745 & $797 . \dot{0}$ & 82360. & 74.78 & .0172 & 795.4 & .0171 & $.241:$ \\
\hline
\end{tabular}




\title{
APPENDIX A: INSTRUMENTED MECHANICAL
}

\section{TEST DATA FOR ALL SPECIMENS}

\section{(continued)}

\author{
LOCXEZD MISSILES \& SPACE $D$. \\ MATERIALS \& PROCESCE JESINSERIM \\ DPT. $75-30$
}

3 Foint Cosoressive Test-5.1. Units. Fiam Data

Test type: Coepressive

Doerator name: CHAFEY

Samole Identitication: FA

Interface Type: 4500 Series

Machine Faraceters of test:

$$
\text { Sacole Rate (pts/sec): }
$$

Crossnead Soeed (wa/nin ): 1.270
Instron Corporation

Series IX futcoated haterials Testing Svsten 1. ve Test Date: of Feb 1993

Sasole Type: ASTH

Huadity (Z): 50

Tecoerature loeg. 5): 73

REQLETTOR DAN CHAFET

Dimensions:

Spec. 1 Sorc. 2 Sook. 3 Spec. 4 Sper. 5 Sper. 1 Soec. 7 Soer. 8

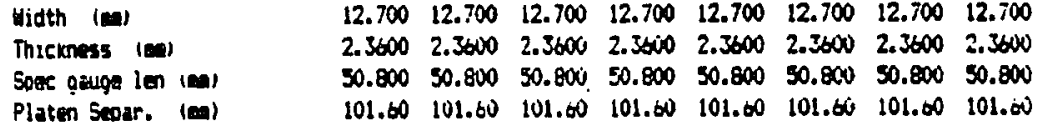

Out of 10 specisens, 0 excluoed.

\begin{tabular}{|c|c|c|c|c|c|c|c|c|c|c|}
\hline $\begin{array}{l}\text { Soecianen } \\
\text { Numoer }\end{array}$ & LD: & $\begin{array}{l}\text { Displ csent } \\
\text { at } \\
\text { Mux. Losd } \\
\text { (ma) }\end{array}$ & $\begin{array}{l}\text { Laad } \\
\text { at } \\
\text { Max.Laxd } \\
\text { (KA) }\end{array}$ & $\begin{array}{l}\text { Stress } \\
\text { at } \\
\text { Max.Ladd } \\
\text { (1rad) }\end{array}$ & $\begin{array}{l}\text { Mooulus } \\
\text { (Autroung) } \\
\text { (fria) }\end{array}$ & $\begin{array}{l}\text { Strase } \\
\text { at otfset } \\
\text { yield I } \\
\text { (Fa) }\end{array}$ & $\begin{array}{l}\text { Strain } \\
\text { at offset } \\
\text { Vield I } \\
\text { (a) }\end{array}$ & $\begin{array}{l}\text { Strass } \\
\text { at user } \\
\text { Break } \\
(1 P a)\end{array}$ & $\begin{array}{c}\text { Strasn } \\
\text { at user } \\
\text { Break } \\
\text { (ص⿴囗⿰丨丨 })\end{array}$ & $\begin{array}{l}\text { Load } \\
\text { at user } \\
\text { Break } \\
(\mathrm{kH})\end{array}$ \\
\hline 1 & FAI & 2.896 & .6877 & 731.7 & 79260. & 715.20 & .0158 & 731.7 & .0162 & .687 \\
\hline 2 & $F A Z$ & 2.743 & .0691 & 710.9 & TAFOOD. & 650.10 & .0157 & 705.1 & .0153 & .6004 \\
\hline 3 & FA3 & 2.870 & .6904 & 734.0 & 79090. & 654.90 & .0143 & 731.9 & .0160 & .6973 \\
\hline 4 & FAA & 2.845 & .6944 & 788.8 & 61860. & 97.23 & .0159 & 756.4 & .0159 & .6921 \\
\hline 5 & FAS & 3.048 & .7429 & 790.4 & 82770. & 463.10 & .0170 & 799.6 & .0170 & .7421 \\
\hline 6 & FAC & 2.718 & .6550 & 694.8 & 81400. & 236.00 & .0151 & 691.6 & .0151 & .6500 \\
\hline 7 & FA7 & 2.819 & .0663 & 709.0 & 79000. & 622.10 & .0157 & 700.2 & .0158 & .0050 \\
\hline$g$ & FAA & 2.896 & .6761 & 719.4 & 79990. & 652.80 & .0138 & 706.8 & .0169 & .0043 \\
\hline 9 & FAP & 2.819 & .6681 & 710.9 & 79230. & 652.30 & .0140 & 700.0 & .0157 & .6654 \\
\hline 10 & Falo & 2.896 & .6552 & 697.2 & 78400. & 638.50 & .0141 & 694.7 & .0162 & .6529 \\
\hline Man: & & 2.855 & .0802 & 723.8 & 80150 & 532.70 & .0147 & 720.8 & $.0160^{\prime}$ & .67 .4 \\
\hline $\begin{array}{l}\text { Stendard } \\
\text { Deviation: }\end{array}$ & & .092 & .0261 & 27.8 & 1406. & 205.60 & .0012 & 28.7 & .00006 & $.027 \dot{v}$ \\
\hline Hiniams: & & 2.718 & .6530 & 694.8 & 78400 & 97.23 & .0157 & 691.0 & .0151 & .0500 \\
\hline Max1sua: & & 3.048 & .7429 & 790.4 & 82770. & 715.20 & .0170 & 789.0 & .0170 & $.74 \hat{a} 1$ \\
\hline
\end{tabular}




\section{APPENDIX A: INSTRUMENTED MECHANICAL TEST DATA FOR ALL SPECIMENS}

\section{(continued)}

LOCKNEED MISSILES \& SAEE CO. MATERIRLS \& FROCESES ENGINERIIG

DEPT. $76-30$

: Fount Compessive Test-5.I. Units. Kay Iata

Test type: Comoressive
Doerater nace: CHAfEy

Sanole Identification: EA

Interface Type: 4560 Sories

Macnune Paraecerers of teat:

$$
\text { Sapple Rate (otsises): } \quad 10.00
$$

Crosshead 5oeed imerein I: 1.270
Instron Lorooration

Series ix Autoasted Materials Testing justem 1. i8 Test Date: CA Feb 1993

Saple Type: ASTH

Huasoity $1:$ : : So

Temperature ideq. Fi: 3

REDESTOK DAN CHAFEY

Dicenstors:

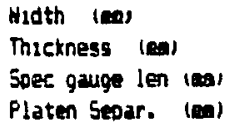

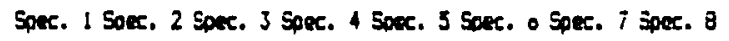

$\begin{array}{llllllll}12.700 & 12.700 & 12.700 & 12.700 & 12.700 & 12.700 & 12.700 & 12.700\end{array}$

$\begin{array}{llllllll}2.4100 & 2.4100 & 2.4100 & 2.4100 & 2.4100 & 2.4100 & 2.4100 & 2.4100\end{array}$

$50.800 \quad 50.800 \quad 50.800 \quad 50.800 \quad 50.800 \quad 50.800 \quad 50.800150 .800$

$101.60101 .00101 .00101 .60 \quad 101.60 \quad 101.00101 .00101 .00$

out of 8 soeccinens. iv excludard.

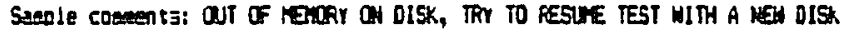

\begin{tabular}{|c|c|c|c|c|c|c|c|c|c|c|}
\hline $\begin{array}{l}\text { Specion } \\
\text { Nutber }\end{array}$ & ID: & $\begin{array}{l}\text { Disolenent } \\
\text { at } \\
\text { max.Load } \\
\text { (en) }\end{array}$ & $\begin{array}{l}\text { Load } \\
\text { at } \\
\text { hax.lond } \\
\text { (KN) }\end{array}$ & $\begin{array}{c}\text { Strass } \\
\text { at } \\
\text { max.Layd } \\
\text { (Fip) }\end{array}$ & $\begin{array}{l}\text { Modulus } \\
\text { (Autroung) } \\
\text { (fod) }\end{array}$ & $\begin{array}{l}\text { Stress } \\
\text { dt offest } \\
\text { ruld } 1 \\
\text { (Fipd }\end{array}$ & $\begin{array}{l}\text { Strain } \\
\text { at of twes } \\
\text { rield } 1 \\
\text { (eayen }\end{array}$ & $\begin{array}{l}\text { Stress } \\
\text { at usor } \\
\text { break } \\
\text { (trFas }\end{array}$ & $\begin{array}{l}\text { Strain } \\
\text { at usar } \\
\text { Ereatk } \\
\text { Iavalat }\end{array}$ & $\begin{array}{l}\text { Load } \\
\text { at Lser } \\
\text { Break } \\
\text { (KN) }\end{array}$ \\
\hline 1 & EAI & 2.794 & هب⿻و. & 715.6 & 81560. & 047.2 & .0138 & 715.7 & .0150 & .6367 \\
\hline 2 & 62 & 2.569 & $.60-16$ & 692.4 & 81700 , & 560.5 & .0119 & 606.0 & .0155 & .5816 \\
\hline 3 & EAJ & 2.591 & .6343 & 600.9 & e0380. & 504.9 & .0109 & 650.8 & .0144 & ت5 \\
\hline 5 & EA5 & 2.921 & .7313 & 762.0 & 81320. & 027.5 & .0134 & 759.2 & .0163 & .7287 \\
\hline 0 & EAb & 2.769 & .6784 & 706,8 & 81730. & 380.9 & .015 & 651.7 & .0155 & .0250 \\
\hline 7 & EA7 & 2.794 & & 700.2 & 81310. & 590.9 & .0125 & 705.9 & .0156 & .0775 \\
\hline$\theta$ & EAD & 2.819 & .7157 & $745 . i$ & 81090. & 651.0 & .0157 & 74.5 & .0158 & .7145 \\
\hline
\end{tabular}

\begin{tabular}{|c|c|c|c|c|c|c|c|c|c|}
\hline hent & 2.772 & .6842 & 712.9 & 81290. & 608.6 & .0130 & 694.0 & .0155 & .0000 \\
\hline \multicolumn{10}{|l|}{ Stanoard } \\
\hline Deviation: & .093 & .0290 & 30.9 & 430. & 60.2 & .0013 & 31.3 & .0015 & $.047:$ \\
\hline Minieses: & 2.591 & .0343 & 660.9 & 80380. & 504.9 & .0109 & 606.0 & .0144 & .5810 \\
\hline Maxioum: & 2.721 & .7313 & 762.0 & 61930. & 697.8 & .0149 & 739.2 & .0163 & .7297 \\
\hline
\end{tabular}




\title{
APPENDIX A: INSTRUMENTED MECHANICAL TEST DATA FOR ALL SPECIBAENS \\ (continued)
}

\author{
LOCKVEES MISSILES \& SFACE CO. \\ MATEFIALS \& FRDCESEES EHGINEETING \\ UEFT. 78-30
}

B Point Comoressive iest-5.1. Undts. Kay Data

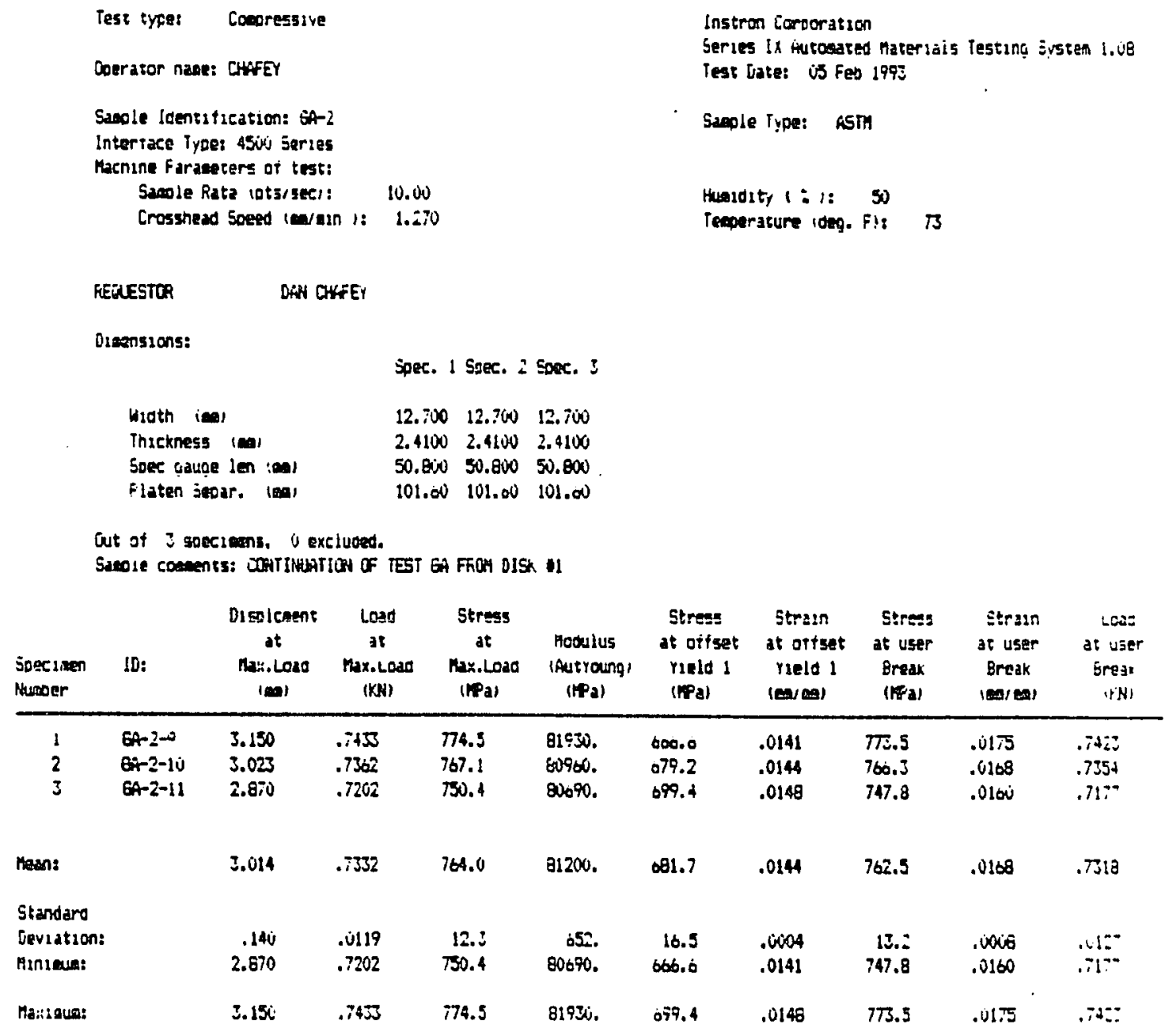




\title{
APPENDIX A: INSTRUMENTED MECHANICAL TEST DATA FOR ALL SPECIMENS \\ (continued)
}

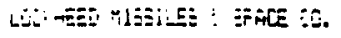

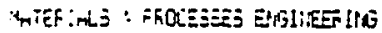 \\ IEFT. E-:

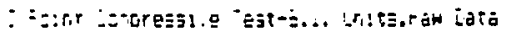

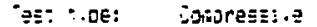

Sperztor nase: FHafer

janole Identification: iti

interiace Tyoe: 45 iw jeries

Macnzne Faraceters of test:

Sample fate lotsisec): lu.wi

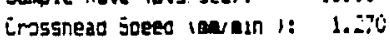

Instron ieroorstion

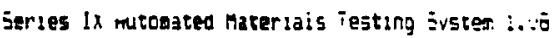
Test Date: ito Fet 199:

Samoig Tyoe: heTM

Huasdity : i i: So

Tequerature ideg. Fi: 15

FEAEETSR DHA CHFEY

Diensions:

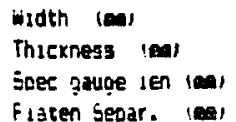

Width rea

Soer zauọe len tae

Fiaren separ. ian
Soec. 1 Soec. : Spec. I Soec. 4 Spec. 9 Soec. o Soec. 7 Scee. 8

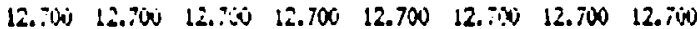

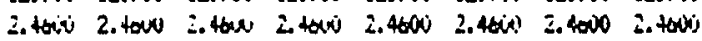

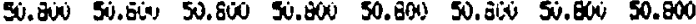

101.011 101.00 $101.00101 .00101 .00101 . \infty 0101.60 \quad 101.00$

Gut at lib soecians. it excluoed.

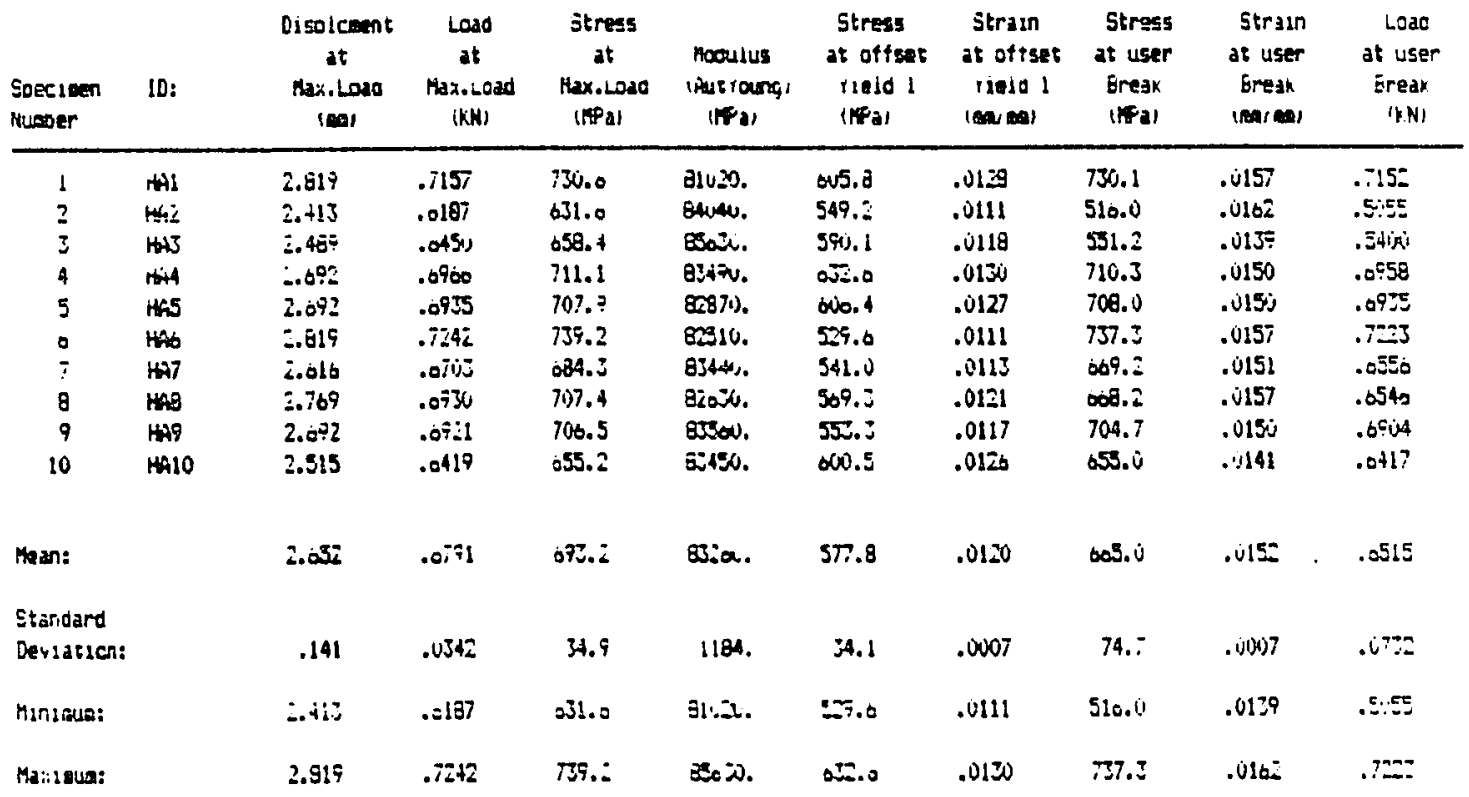




\section{APPENDIX A: INSTRUMENTED MECHANICAL}

\section{TEST DATA FOR ALL SPECIMENS}

\section{(continued)}

\section{LOCKSEE MISSILES \& SFACE CO.}

MATEIHLS \& PROCESSE BVINEETING

CEFT. TE-30

S Folnt Lcooressive Test-J.1. Unit5, ham lata

Test trpe: Conpressive

Coerator naos: CHAFEi

Sacole ldentitieation: $A$ A

Interface Type: 4501 Series

Macnsne Furzoerers of test:

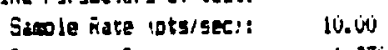

Crossnead Joeed !moun it: 1.270
Instron iontorsison

Series Ix Hutoested Materiais Testing Sistem 1. L16 Test Date? Do Fed 1793

- Sarola Type: ASTM

Hesidit; 1: 1: 50

Texoerature (deq. F): 73

REDLETOR UAN CHAFEY

Oienenstons:

Spec. 1 Soec. : Sooc. 3 Spec. + Spec. 9 Spec. o Soer. 7 Soec. B

\begin{tabular}{|c|c|c|c|c|c|c|c|c|}
\hline Ith & 12.700 & $12.7 \% 0$ & 12.700 & 12.700 & 12.700 & 12.700 & 12.700 & 12.700 \\
\hline Irckness (end & 2.3400 & $2.3+(x)$ & & 3400 & & & $\begin{array}{l}2.5400 \\
50.200\end{array}$ & $\begin{array}{l}2.34(0) \\
50.600\end{array}$ \\
\hline ten separ. ies & & & & & $10: 00$ & 101.60 & 1001.00 & 101.50 \\
\hline
\end{tabular}

Out of 10 soecieans, if excludea.

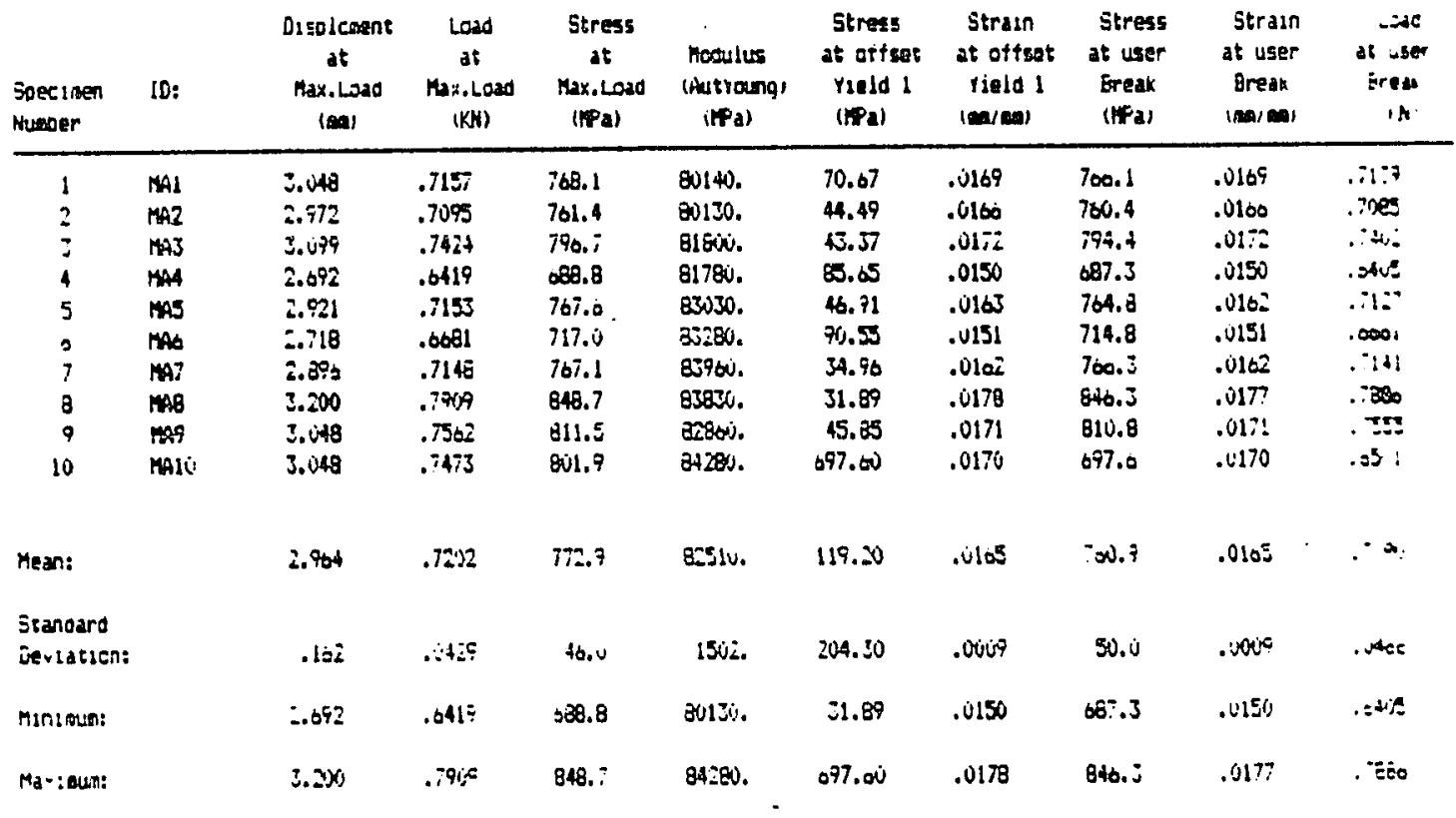




\title{
APPENDIX Â: INSTRUMENTED MHECHANHCAL \\ TEST DATA FOR ALL SPECIMENS
}

\section{(continued)}

\author{
LOCKHEDD MISSILES \& SPACE CO. \\ MATERIALS \& PROCESSES ERINEERING \\ DEPT. 78-30
}

3 Fount Conoressive Test-5.L. Units, Fias Lata

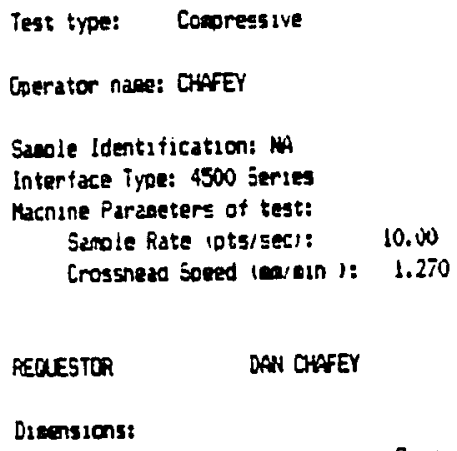

Test type: Cospressive

Cperator naee: CHAFEY

Sanole Identification: MA

Interface iype: 4500 series

Macnine Paraeters of test: Samole Rate ipts/seci: 10.00
Crossnesa Soeed iearoin ): 1.270

PECLESTOR DAN CHAFEY

Diesensions:

Instron iorooration Series IX intoosted haterials iesting System 1.vö Test bate: of Feo 1998

Sacole Type: ASTH

Heardity ( Z ): 50

Tecoerature (deq. F): 73

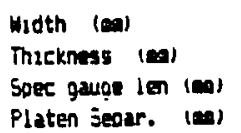

5pec. 1 Speec. 2 Spac. 3 Soec. 4 Soex. 5 Soer. 6 Soer. 7 Spac. a

$\begin{array}{llllllll}12.700 & 12.700 & 12.700 & 12.700 & 12.700 & 12.700 & 12.700 & 12.700\end{array}$

$\begin{array}{llllllll}2.5500 & 2.3500 & 2.3300 & 2.5500 & 2.5500 & 2.5500 & 2.5500 & 2.5000\end{array}$

$\begin{array}{llllllllllllllll}50.600 & 50.800 & 50.500 & 50.800 & 50.800 & 50.800 & 50.800 & 50.800\end{array}$

$101.60 \quad 101.00101 .00101 .60101 .00101 .00101 .60101 .60$

Out of 10 specisens, is exeluoad.

\begin{tabular}{|c|c|c|c|c|c|c|c|c|c|c|}
\hline $\begin{array}{l}\text { Soecicen } \\
\text { theoper }\end{array}$ & ID: & $\begin{array}{l}\text { Disol coment } \\
\text { at } \\
\text { tax.Laso } \\
\text { (ea) }\end{array}$ & $\begin{array}{l}\text { Load } \\
\text { at } \\
\text { Max.Load } \\
\text { (BN) }\end{array}$ & $\begin{array}{l}\text { Stress } \\
\text { at } \\
\text { Max.Load } \\
\text { (ipla) }\end{array}$ & $\begin{array}{l}\text { Mooulus } \\
\text { (Autroung) } \\
\text { (iPa) }\end{array}$ & $\begin{array}{l}\text { Stress } \\
\text { at offeet } \\
\text { Yield } 1 \\
\text { (Fi) }\end{array}$ & $\begin{array}{l}\text { Strain } \\
\text { at oftest } \\
\text { yiald } 1 \\
\text { (a) }\end{array}$ & $\begin{array}{l}\text { Stress } \\
\text { at user } \\
\text { Break } \\
\text { (1fra) }\end{array}$ & $\begin{array}{c}\text { Strain } \\
\text { at user } \\
\text { Bredk } \\
10 / \infty 1\end{array}$ & $\begin{array}{l}\text { Load } \\
\text { at user } \\
\text { Break } \\
(\mathrm{KH})\end{array}$ \\
\hline 1 & NA1 & 2.794 & b700ة. & $716 . a$ & 202570 . & 112.50 & .0157 & 715.7. & \$ & .6078 \\
\hline 2 & N*2 & 2.921 & .7108 & 759.6 & 79010. & 517.00 & .0112 & 759.2 & .0162 & .7104 \\
\hline 3 & Z & 2.870 & .7035 & 755.7 & 82730. & 140.20 & .0160 & 750.7 & .0160 & $.70=8$ \\
\hline 4 & mas & 2.997 & . 7300 & 780.9 & 81340. & 94.18 & .0167 & $\pi 8.5$ & .0167 & .7286 \\
\hline 5 & $\mathrm{NA}$ & 2.692 & .6503 & 694.9 & $005 i 0$. & 383.40 & $.015 j$ & 693.2 & .0149 & .0467 \\
\hline 6 & 100 & 3.179 & .774 & 827.5 & 82330. & 111.30 & $.01 \pi$ & 826.9 & . & .739 \\
\hline 7 & Na7 & 2.819 & .6077 & 734.8 & BA910. & 117.90 & .0151 & 733.8 & .0157 & .6807 \\
\hline 6 & 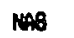 & 3.023 & .7446 & 793.7 & 83640. & 787.20 & .0170 & 790.3 & .0170 & .7396 \\
\hline 9 & $N$ & 3.049 & .7491 & 800.4 & 82750 & 4.37 & .0170 & 799.2 & .0170 & .7480 \\
\hline 10 & M10 & 2.921 & .7286 & 778.6 & 84070. & 102.20 & .0163 & 775.5 & .0163 & .758 \\
\hline man: & & 2.926 & .7155 & 764.3 & 86570 & 241.00 & .0150 & 762.3 & .0103 & .7134 \\
\hline $\begin{array}{l}\text { Standard } \\
\text { Deviatzon: }\end{array}$ & & .141 & .0380 & 40.6 & 1605. & 243.30 & .0018 & 40.4 & .0008 & .0576 \\
\hline Aini axes: & & 2.692 & .6503 & 694.9 & 79010. & 44.57 & .0112 & 693.2 & .0149 & .0487 \\
\hline Maxiaua: & & 3.175 & .7744 & 827.5 & 84910. & 787.20 & .0177 & 826.9 & .017 & .7759 \\
\hline
\end{tabular}




\title{
APPENDIX A: INSTRUAENTED MECHANICAL
}

TEST DATA FOR ALL SPECIMENS

(continued)

\author{
LOCKHEED HISSILES \& SFALE CD.

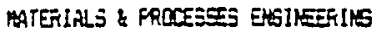 \\ DEFT. ?t-30
}

Z Eolne Ecoores5ive Test-5.1. Unsts. faw lata

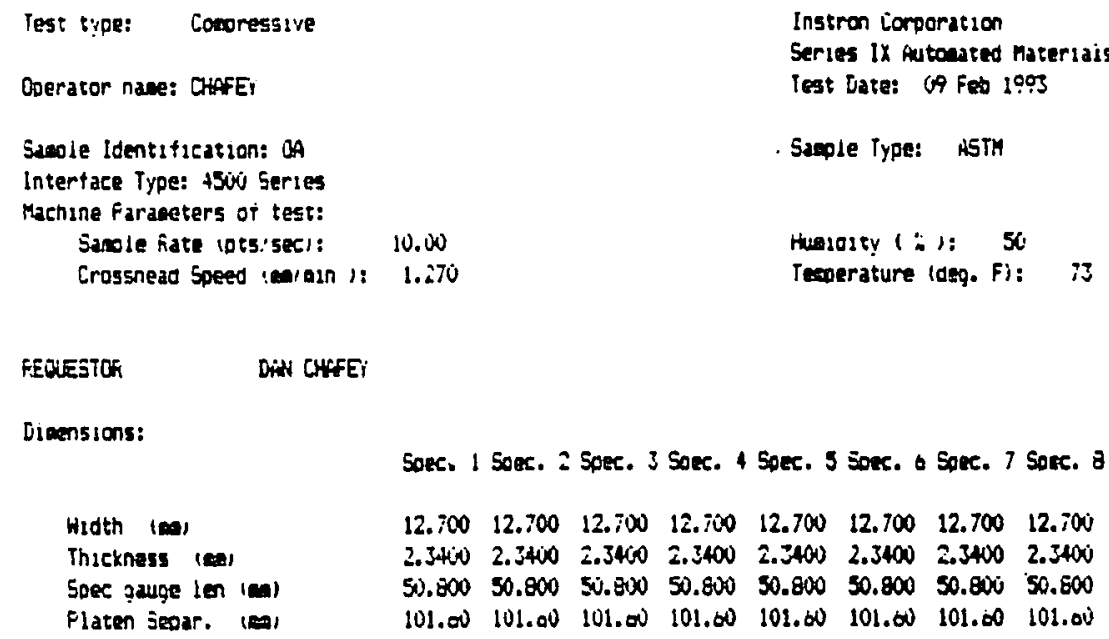

Out of tiv specisens. is exclueged.

\begin{tabular}{|c|c|c|c|c|c|c|c|c|c|c|}
\hline $\begin{array}{l}\text { Scec: aen } \\
\text { Mumoer }\end{array}$ & ID: & $\begin{array}{c}\text { Disolcnent } \\
\text { at } \\
\text { fiax.Loso } \\
\text { 1. }\end{array}$ & $\begin{array}{l}\text { Load } \\
\text { at } \\
\text { Max.Lodd } \\
\text { (IN) }\end{array}$ & $\begin{array}{c}\text { Stress } \\
\text { at } \\
\text { Hay. Load } \\
\text { (tral }\end{array}$ & $\begin{array}{l}\text { noovilus } \\
\text { (Autrourag) } \\
\text { (1Pa) }\end{array}$ & $\begin{array}{l}\text { Stross } \\
\text { at oftset } \\
\text { rielo } 1 \\
\text { (IRa) }\end{array}$ & $\begin{array}{l}\text { Strain } \\
\text { at offset } \\
\text { lield I } \\
\text { (ea, oa ) }\end{array}$ & $\begin{array}{l}\text { Stress } \\
\text { at user } \\
\text { Brsan } \\
\text { (Fifal }\end{array}$ & $\begin{array}{c}\text { Strain } \\
\text { at user } \\
\text { Oraak } \\
\text { Ina/ ant }\end{array}$ & $\begin{array}{l}\text { Loao } \\
\text { at user } \\
\text { Ereak } \\
\text { (WN) }\end{array}$ \\
\hline 1 & Gil & 3.048 & .7100 & 709.1 & 78960. & 762.40 & .0150 & 767.1 & ivlä & $.71+9$ \\
\hline 2 & $\mathrm{OA}_{2}$ & 2.896 & .7000 & 751.8 & Bustiv. & 500.20 & .010 & 712.0 & .0163 & $.604 i$ \\
\hline$j$ & Cas & 2.870 & .0779 & 749.0 & 8v99.i. & 757.50 & .0158 & 758.3 & .0162 & $.08 E 0$ \\
\hline 4 & 004 & 2.940 & $.087 \%$ & 738.0 & 23460. & 705.90 & .0157 & 757.8 & .0165 & .6870 \\
\hline 5 & CAS & 2.972 & .7286 & 781.9 & 84590. & 46.18 & .0160 & $\pi 9.3$ & . نl & .7206 \\
\hline$b$ & 000 & 2.946 & . & 778.1 & Q35iv. & 48.20 & .0155 & 70.3 & .0164 & .7254 \\
\hline 7 & QA? & 2.940 & .7264 & 779.5 & $85: 20$. & 150. & .0105 & $\pi T .0$ & .0104 & .7240 \\
\hline g & OAB & 2.772 & .7265 & 780.0 & $8<090$. & 65. i6 & .0165 & 778.5 & .0165 & .8255 \\
\hline 9 & CAP & 2.845 & ot.07. & 721.8 & $7850 \%$. & 714.90 & .0157 & 717.7 & .ùlez &.$\infty 7 i$ \\
\hline 10 & CA10 & 2.591 & .0055 & 655.0 & 77050. & 543.60 & .0120 & 570.7 & .0108 & .5320 \\
\hline Mean: & & 2.513 & . & $750 . i$ & $814 i j$. & 427.80 & .0158 & 733.0 & .0165 & .0855 \\
\hline \multicolumn{11}{|l|}{ Standard } \\
\hline Deviation: & & .124 & .0371 & 39.8 & $50 \%$. & 312.90 & .0021 & $\infty .4$ & .0002 & . \\
\hline Maniana: & & $\therefore$.5?! & .5489 & 653.0 & $7 i s 5 i$. & 76.48 & $.010 B$ & 570.9 & .u162 & .524 \\
\hline Aaxioum: & & 3.648 & o & $781 .:$ & 845\%1. & $162 .+10$ & . نles & 779.5 & $.010 \%$ & $\therefore$ \\
\hline
\end{tabular}




\title{
APPENDIX A: INSTRUMENTED MECHANICAL TEST DATA FOR ALL SPECIMENS \\ (continued)
}

\author{
LOCKKEED AIGSILES \& SPACE CO. \\ MATERIALS \& FROCESES ENGINEERING \\ [E]T. TE-JU
}

3 fount idocoresgive iest-5.1. Units, Faw Data

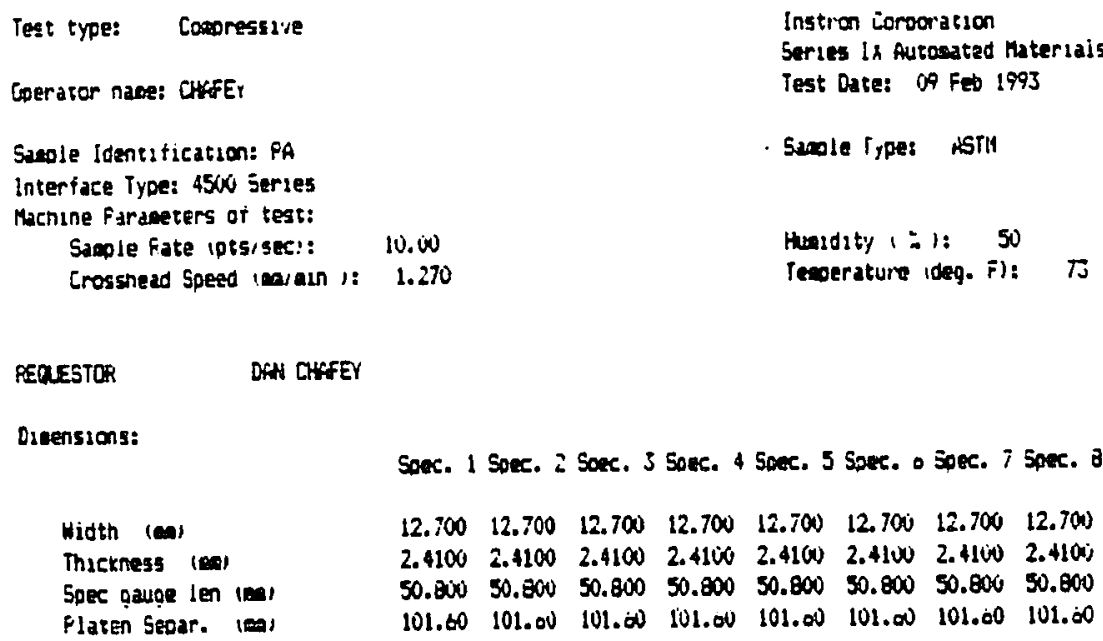

out of 16 soecieens. O exclubed.

\begin{tabular}{|c|c|c|c|c|c|c|c|c|c|c|}
\hline $\begin{array}{l}\text { Soecinen } \\
\text { Nanjer }\end{array}$ & ID: & $\begin{array}{c}\text { Disolcsent } \\
\text { at } \\
\text { thas.ioas } \\
\text { (a) }\end{array}$ & $\begin{array}{l}\text { Load } \\
\text { at } \\
\text { Fata:LLad } \\
\text { (Kt) }\end{array}$ & $\begin{array}{c}\text { Stress } \\
\text { at } \\
\text { Max.Lodo } \\
\text { (risa) }\end{array}$ & $\begin{array}{l}\text { Podulus } \\
\text { (Asutroung| } \\
\text { (If Fa) }\end{array}$ & $\begin{array}{l}\text { Stres: } \\
\text { at offset } \\
\text { rield ! } \\
\text { (FPal }\end{array}$ & $\begin{array}{l}\text { Strian } \\
\text { at offset } \\
\text { pueld } 1 \\
\text { [aueas }\end{array}$ & $\begin{array}{l}\text { Stress } \\
\text { at uspr } \\
\text { Brest } \\
\text { (FPa) }\end{array}$ & $\begin{array}{c}\text { Straln } \\
\text { at user } \\
\text { Erteat } \\
\text { iseas }\end{array}$ & $\begin{array}{l}\text { Load } \\
\text { at user } \\
\text { Erejk } \\
\text { (KN) }\end{array}$ \\
\hline 1 & FAI & 2.972 & .7019 & 731.4 & $\pi 120$ & 612.5 & .0130 & 30.2 & .0160 & $.700 E$ \\
\hline 2 & $F G 2$ & 2.845 & .610 & 600.7 & 79390. & 548.4 & .0119 & $\infty 2.2$ & .0164 & .6755 \\
\hline$j$ & FAJ & 2.769 & .6534 & 380.9 & 19360. & 455.9 & .0100 & bov.l & . 1155 & .0055 \\
\hline 4 & Fit & 2.718 & .0437 & 670.7 & 77500 & 594.3 & .0133 & 050.7 & .0161 & .0245 \\
\hline 5 & PAS & 2.769 & .6792 & $707 . i$ & 79390. & $690 . \dot{ن}$ & .0152 & 705.1 & .0154 & .6767 \\
\hline 6 & FHA & 2.007 & .0429 & 669.7 & 77910. & 020.8 & .0157 & $\infty 01.6$ & $.015 i$ & . \\
\hline 7 & PAT & 2.819 & |b7ol. & 704.5 & TEJî. & 561.8 & .0121 & 702.7 & $.015 \pi$ & .0744 \\
\hline$\theta$ & FAB & 2.819 & .0910 & 709.6 & 80070 & 616.5 & .0135 & 700.2 & .0157 & .6797 \\
\hline 9 & PAP & 2.769 & .0703 & 098.5 & T900w. & 542.7 & . $0111 \bar{i}$ & 090.0 & . U1LS & .008 \\
\hline 10 & F 410 & 2.972 & .7040 & TTA.2 & 79320. & 613.7 & .0133 & $T 32.2$ & .0165 & .7027 \\
\hline Man: & & 2.812 & .0714 & 699.0 & 78850. & 380.3 & & a91.0 & .0150 &.$\infty 11$ \\
\hline $\begin{array}{l}\text { Stanoard } \\
\text { Deviation: }\end{array}$ & & 94. & .0217 & 2.6 & 1004. & 03.8 & .0014 & 30.1 & . vins & . $5=8^{\circ}$ \\
\hline Manjeus: & & 2.667 & .6425 & 667.7 & 77120. & 455.9 & & 650.7 & .00150 & .6245 \\
\hline Max1 aum: & & 2.772 & .7040 & 734.2 & QCONī. & 096.3 & $.015 E$ & 73.2 & .0160 & $\therefore$ \\
\hline
\end{tabular}




\section{APPENDIX A: INSTRUMENTED MECHANICAL \\ TEST DATA FOR ALL SPECIRENS}

\section{(continued)}

LOCKHEES MISSILES 2 FFACE CO.

MATERIRLS : FROCESSES DGINEERING

DEPT. $70-30$

3 Point Coopressive Test-s.1. Units, fian Lata

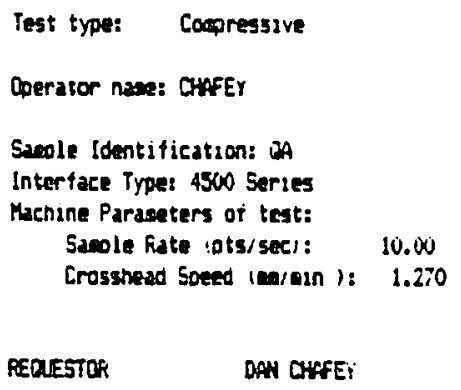

Divensions:

Hidth (a)
Thickness (m)
Soec gauge Ion (an)
Platen Separ. (an)

Soec. 1 Soec. I Spec. 3 Soec. 4 Soec. 5 Soec. o Soec. 7 Soec. A

$\begin{array}{llllllll}12.700 & 12.700 & 12.700 & 12.700 & 12.700 & 12.700 & 12.700 & 12.700\end{array}$

$\begin{array}{lllllllll}2.4800 & 2.4800 & 2.4800 & 2.4800 & 2.4900 & 2.4800 & 2.4800 & 2.4000\end{array}$

$\begin{array}{lllllllllllll}50.800 & 50.000 & 50.800 & 50.800 & 50.800 & 50.800 & 50.000 & 50.800\end{array}$

$101.00101 .60 \quad 101.00101 .00101 .00101 .60101 .60101 .60$

Dut of 10 soecreens, 0 exciuded.

Sample coremtsi $0.16 \%$ FEP

\begin{tabular}{|c|c|c|c|c|c|c|c|c|c|c|}
\hline $\begin{array}{l}\text { Soecisen } \\
\text { Heder }\end{array}$ & 10: & $\begin{array}{c}\text { Disolcemt } \\
\text { at } \\
\text { Hax.Load } \\
\text { ted }\end{array}$ & $\begin{array}{l}\text { Lasd } \\
\text { at } \\
\text { Max.Lond } \\
\text { (KH) }\end{array}$ & $\begin{array}{l}\text { Stress } \\
\text { at } \\
\text { Max.load } \\
\text { (Fa) }\end{array}$ & $\begin{array}{l}\text { Aloulus } \\
\text { (Autrang) } \\
\text { (19a) }\end{array}$ & $\begin{array}{l}\text { Stress } \\
\text { at of fset } \\
\text { rifld } 1 \\
(189)\end{array}$ & $\begin{array}{l}\text { Straun } \\
\text { at offent } \\
\text { Yield } 1 \\
(\mathrm{mes})\end{array}$ & $\begin{array}{l}\text { Stress } \\
\text { at usere } \\
\text { Breat } \\
\text { (Fon) }\end{array}$ & $\begin{array}{l}\text { Strain } \\
\text { at user } \\
\text { Break } \\
\text { (ave }\end{array}$ & $\begin{array}{l}\text { Load } \\
\text { at user } \\
\text { Break } \\
\text { (KN) }\end{array}$ \\
\hline 1 & CA1 & 2.819 & .6984 & 707.1 & 79070. & 649.5 & .0143 & 707.2 & .0157 & . 6984 \\
\hline 2 & 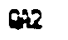 & 2.819 & .7157 & 726.7 & TF्ञाర. & ovj.v & .0130 & 72.4 & .0150 & $.7 ! 34$ \\
\hline 3 & CAS & 2.464 & .6414 & 649.5 & 81370. & 640.6 & .0138 & 649.0 & .0138 & .6410 \\
\hline 4 & at & 2.896 & .7420 & 731.3 & Buito. & 715.9 & .0154 & 749.0 & .0161 & .7397 \\
\hline 5 & cos & 2.797 & .7655 & 775.1 & EQ47\%. & 121.9 & .0153 & 775.2 & .0167 & .7650 \\
\hline 0 & as & 2.794 & .7522 & 741.4 & 81090. & 583.5 & . v̇l23 & 740.8 & $.015 s$ & .7317 \\
\hline 7 & M7 & 2.642 & .6641 & 672.4 & 81000. & $4 \pi .1$ & .0100 & 670.4 & .0146 & .6621 \\
\hline 8 & 60 & 2.565 & .0041 & 672.4 & 81730. & 559.8 & .0120 & 507.7 & .0149 & .5500 \\
\hline 9 & 098 & 2.515 & .0263 & 634.2 & EO2\%. & 520.3 & .0111 & 319.8 & .0179 & .5134 \\
\hline 10 & OA1O & 2.311 & .5912 & 598.6 & sosiv. & 500.0 & .0106 & 497.9 & .0159 & .4819 \\
\hline \multicolumn{2}{|l|}{ Meni } & 2.602 & .6841 & 692.7 & 80930. & 599.0 & .0138 & 057.9 & .0157 & .6498 \\
\hline \multicolumn{11}{|l|}{ Stanoary } \\
\hline Deviation: & & .217 & .0539 & 56.0 & 1084. & 64.2 & .0019 & 102.1 & .0011 & .1008 \\
\hline Miniesa: & & 2.311 & .5912 & 599.6 & 79070. & $4 \pi .1$ & .0100 & 487.9 & .0138 & .4819 \\
\hline Maxiaun: & & 2.997 & .7555 & 775.1 & exaio. . & 121.9 & .0153 & 775.2 & .0179 & .7656 \\
\hline
\end{tabular}




\title{
APPENDIX A: INSTRUMENTED MECHANICAL TEST DATA FOR ALL SPECIMENS (continued)
}

\author{
LOCREED MISSILES \& SPALE CO. \\ RATEIALS \& FFOCEESES EHGINEESIIT \\ LEFi?. ig-iv

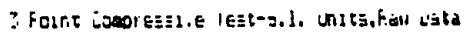

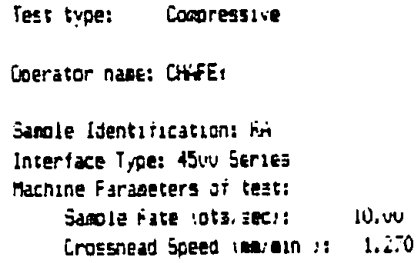

FEQESTOK IAN CHFEY

Dieensions:

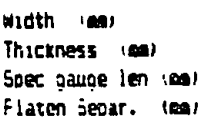

Snec. I Soec. I Spec. I Soec. 4 Sper. 5 Soec. o joec. i Soec. a

12.70012 .700 12.700 $12.700 \quad 12.700 \quad 12.700 \quad 12.700 \quad 12.700$

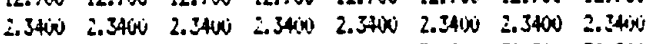

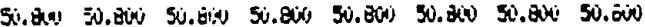

flaten jeoar. teal

luil.ov lut.ou 1ul.ov lul.ev lul.ov 101.00101 .00101 .00

Gut of 10 soecinens, is excluoes.

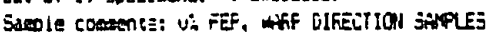

\begin{tabular}{|c|c|c|c|c|c|c|c|c|c|c|}
\hline $\begin{array}{l}\text { Soecinen } \\
\text { thusouer }\end{array}$ & IDt & $\begin{array}{c}\text { ujgolesent } \\
\text { at } \\
\text { Max.Losd } \\
\text { Ime }\end{array}$ & $\begin{array}{c}\text { Loao } \\
\text { at } \\
\text { Fa:.Load } \\
\text { (HH) }\end{array}$ & $\begin{array}{l}\text { Stresa } \\
\text { at } \\
\text { Max.Load } \\
(\text { HPal }\end{array}$ & $\begin{array}{l}\text { Hooulus } \\
\text { (Aut roungl } \\
\text { (If a) }\end{array}$ & $\begin{array}{l}\text { Stress } \\
\text { at oftset } \\
\text { rield } 1 \\
\text { (lipal }\end{array}$ & $\begin{array}{l}\text { Strain } \\
\text { at oriset } \\
\text { Ijelo } 1 \\
\text { (aurea) }\end{array}$ & $\begin{array}{l}\text { Stress } \\
\text { at user } \\
\text { Break } \\
\left(P_{2}\right)\end{array}$ & 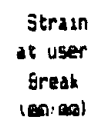 & $\begin{array}{c}\text { Loso } \\
\text { ot -sor } \\
\text { gres. } \\
\text { in }\end{array}$ \\
\hline 1 & PAL & 3.048 & . 309 & $772 . ?$ & glouj. & 40.671 & .0179 & 791.4 & .0170 & $\because 4$ \\
\hline 2 & FGi & 2. Ēo & $.70<4$ & $753 . ?$ & G2u2u. & 34.710 & .0162 & BLI.t & .0162 & $.70=$ \\
\hline 3 & RAJ & 2.870 & .0979 & 749.0 & 81990. & 24.840 & .0161 & 747.1 & زنهان. & $.070:$ \\
\hline 4 & Fon & 2.774 & $.0 \overline{15}$ & 727.0 & 85750. & 54.290 & .0156 & 725.2 & .0156 & $.0 \div$ \\
\hline 5 & Ris & 3.124 & . Toil & 823.: & E<8Qu. & 2.989 & .0175 & 821.7 & .0175 & $\therefore$ oss \\
\hline$b$ & Rito & $=769$ & .0700 & 720.0 & ةis5o. & 53.040 & .0155 & 728.1 & . U1ES & $.0 \div$ \\
\hline 7 & RA7 & 2.972 & $.7 \pm \div 5$ & 782 ? & 932ï. & 10.530 & .0100 & 780.0 & oulob & $\therefore 4$ \\
\hline 8 & RAB & 2.769 & .0 .144 & 725.7 & B4270. & 17.00 & .015 & 720.8 & .0154 & $.0 \div$ \\
\hline 7 & RAF & 2.819 & .000 & 738. i & 82tw. & 17.806 & . ن1158 & TS.5 & .0157 & $. \infty \dot{x}:$ \\
\hline 10 & RA1O & $\hat{2}=642$ & .0388 & 85.5 & 81770. & 35.200 & .0147 & 082.2 & .0140 & $2=$ \\
\hline Masi: & & $2.87 j$ & .0991 & $35 i .2$ & $2205 \%$ & 29.210 & .0100 & i48.: & . & $.0=\because$ \\
\hline \multicolumn{11}{|l|}{ Stangara } \\
\hline Deviation: & & .145 & .0774 & 4.1 & BE?. & $17 .+90$ & . v0le & 413.7 & $.00 \times 8$ & $. v: 0$ \\
\hline Mrntaun: & & $2.04 i$ & .0383 & 065.5 & gibiv. & 2.989 & .0147 & 082.2 & .0146 & $.0 .5^{-}$ \\
\hline$M_{2}=1$ 月ua: & & 2.124 & 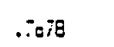 & 02: & $242 \%$ & 54.29 & & Q81.7 & .0175 & . $-x=$ \\
\hline
\end{tabular}




\section{APPENDIX A: INSTRUMENTED MECHANICAL \\ TEST DATA FOR ALL SPECIMENS \\ (continued)}

\section{LOCKHESI MISSILES \& SPACE CO.}

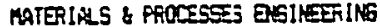

[EFT. 78-30

I Fount Compressive iest-j.1. Units, Ram taka

Test type: Coraressive

Coerator naen: CHAFi

Sanose Identification: SA Interface iype: 4500 Series

Macnine Parabeters of test: Samole fate lotzisee::

Crosshezd Soetd (masean 1: $1.27 \mathrm{j}$
Instron Corooration

Series Id Autowated Materials Testing Systen 1.:i8 Jest Date: II Feb 1993

Sacole Type: ASTh

Hualdity $1:$ i: 50

Temerafure :deq. F): i3

KEOLETLF DAN CHFFE,

Diensions:

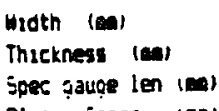

Spec g̣acọe len tmat
Soer. 1 Spec. I Spec. 3 Soec. 4 Spec. 5 Soer. o Spec. i Soec. I

$\begin{array}{llllllll}12.700 & 12.700 & 12.700 & 12.700 & 12.700 & 12.700 & 12.700 & 12.700\end{array}$

$\begin{array}{llllllll}2.5700 & 2.5700 & 2.3700 & 2.5700 & 2.3700 & 2.5700 & 2.5700 & 2.5700\end{array}$

$\begin{array}{llllllllllllll}50.800 & 50.800 & 50.800 & 50.800 & 50.800 & 50.800 & 50.800 & 50.800\end{array}$

101.60101 .00101 .00101 .60101 .00101 .00101 .60101 .00

Our of 10 soecinens. O excluous.

Samole coments: $2.18 \%$ FEF, WAFF OIRECTION SNFLES

\begin{tabular}{|c|c|c|c|c|c|c|c|c|c|c|}
\hline $\begin{array}{l}\text { Soecinen } \\
\text { theooser }\end{array}$ & ID: & 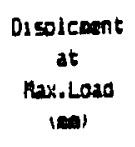 & $\begin{array}{c}\text { Load } \\
\text { at } \\
\text { Max.Load } \\
\text { (kH) }\end{array}$ & $\begin{array}{l}\text { Streas } \\
\text { at } \\
\text { Max.load } \\
\text { (tipa) }\end{array}$ & $\begin{array}{l}\text { oulus } \\
\text { (Autroung) } \\
\text { (tra) }\end{array}$ & $\begin{array}{l}\text { Stross } \\
\text { at oftset } \\
\text { rield } 1 \\
\text { (RRal }\end{array}$ & $\begin{array}{l}\text { Strain } \\
\text { at of teet } \\
\text { rield } 1 \\
\text { ione }\end{array}$ & $\begin{array}{l}\text { Stress } \\
\text { at user } \\
\text { Break } \\
\text { (Fra) }\end{array}$ & $\begin{array}{l}\text { Strain } \\
\text { at user } \\
\text { Breäx } \\
\text { tea/ rol }\end{array}$ & $\begin{array}{l}\text { Load } \\
\text { at user } \\
\text { Breax } \\
\text { R.Ni }\end{array}$ \\
\hline 1 & SAl & 2.845 & .6105 & 653.2 & 77860 & 604.60 & .0152 & 594.5 & .0174 & Esil \\
\hline$i$ & SAÉ & 2.794 & .6921 & 133.4 & $220 \leq 0$. & 693.00 & .0147 & 731.4 & .0155 & .0903 \\
\hline 3 & SAB & 2.921 & .7557 & $m 9.5$ & 84730. & 93.71 & .0164 & 778.1 & .0163 & $. \pi+\pi$ \\
\hline 4 & SA4 & 2.896 & .7184 & 761.2 & $8>840$. & 526.60 & .0161 & 739.2 & .0161 & .7100 \\
\hline 5 & 395 & 3.150 & .7767 & 922.9 & $8 \div 90$. & 52.44 & .0175 & 821.7 & .01175 &.$T 755$ \\
\hline 6 & 596 & 2.179 & $.794 \mathrm{iN}$ & 81.3 & 83490. & 98.54 & .0178 & 941.2 & .0178 & $.794 j$ \\
\hline 7 & SA7 & 3.025 & .7544 & 799.3 & 85400. & 116.40 & .0168 & 798.3 & .0168 & $.755 t$ \\
\hline 8 & 598 & 3.124 & .7762 & 822.4 & 64630. & 800.80 & .0170 & 820.9 & .0173 & $.7+8$ \\
\hline 9 & SAA & 2.946 & .734 & $\pi 78.1$ & 84020. & 141.80 & .0165 & 770.0 & . Vlot & .724 \\
\hline \multirow[t]{2}{*}{10} & SA10 & 2.870 & .7095 & 751.7 & 84090. & 147.90 & .0160 & 749.4 & .0159 & .7070 \\
\hline & & & & & & & & & 4. & \\
\hline Mean: & & 2.974 & . & 774.3 & 83290 & 329.30 & .0102 & 707.1 & .0167 & .7240 \\
\hline $\begin{array}{l}\text { Standard } \\
\text { Deviation: }\end{array}$ & & .136 & .0510 & 54.6 & 2188. & 293.40 & .0014 & 09.7 & .0000 & ניוני. \\
\hline Hinicua: & & 2.794 & .0165 & 653.2 & $T: B S O$ & 52.44 & .0132 & 594.5 & . & .5011 \\
\hline Ma:1 & & 3.175 & .7940 & 841.3 & Estovi. - & 806.80 & .0178 & 841.2 & $.017 \theta$ & $. \quad \therefore 41)$ \\
\hline
\end{tabular}




\title{
APPENDIX A: INSTRUMENTED MECHANICAL \\ TEST DATA FOR ALL SPECIMENS \\ (continued)
}

\author{
LOCNEED MISSILES \& SPACE CO. \\ MATERIALS \& PROCESSES ENSIFERING \\ DETT. $78-30$
}

3 Foint Comoressive Test-5. I. inits. Fian Data

Tast type: Coesoressive

Coerator nawe: QHFEY

Samb Identification: TA

Interfuen Type: 4500 Series

Machine Paracerters of test:

Saenle Rate cotsisers: $\quad 10.00$

Crosentead speed levaln 1: 1.270
Instron Lorporation

Series id Autcateo Materials Testing jvsten i.v8

Test Date: 11 Fob 1993

Sacole Type: ASTh

Husesdity $1: 18 \quad 5$

Temerature 10eg. Fi: is

RERUESTCA DAN AHFEY

Diemarons:

Spec. 1 Soer. 2 Sook. 3 Soec. 4 spec. 3 Soer. o Soec. I Spec. a

\begin{tabular}{|c|c|c|c|c|c|c|c|c|}
\hline idth (av) & 12.700 & 12.700 & 12.700 & 12.700 & 12.700 & 12.700 & 12.700 & 12.700 \\
\hline Thicknass (m) & $\begin{array}{l}2.1300 \\
50.800\end{array}$ & $\begin{array}{l}2.4300 \\
50,000\end{array}$ & 2.4300 & & & 2.4300 & 2.4300 & 2.45000 \\
\hline in Seoar. & 101.60 & 101.60 & $101 . \infty 0$ & $101 . \infty 0$ & 101.00 & 101.60 & 101.01 & $101, \infty)$ \\
\hline
\end{tabular}

Out of 10 soecisens. 0 excluded.

Sabole coments: 4.08i. FE, DAPP DIfECTION SAFLES

\begin{tabular}{|c|c|c|c|c|c|c|c|c|c|c|}
\hline $\begin{array}{l}\text { Soeciaten } \\
\text { hupter }\end{array}$ & ID: & $\begin{array}{c}\text { Diesolement } \\
\text { at } \\
\text { hax.Load } \\
(\infty)\end{array}$ & $\begin{array}{l}\text { Lard } \\
\text { at } \\
\text { Max.Load } \\
\text { (KN) }\end{array}$ & $\begin{array}{c}\text { Stress } \\
\text { at } \\
\text { Aax.Lond } \\
\text { (APa) }\end{array}$ & $\begin{array}{l}\text { Boctuices } \\
\text { (futroung) } \\
(1 P 2)\end{array}$ & $\begin{array}{l}\text { Struss } \\
\text { at offeet } \\
\text { Yield } 1 \\
(\text { Fid })\end{array}$ & $\begin{array}{l}\text { Stroun } \\
\text { at offiset } \\
\text { rieid } 1 \\
\text { (mose }\end{array}$ & $\begin{array}{l}\text { Stress } \\
\text { at user } \\
\text { Brese } \\
\text { (1Pa) }\end{array}$ & $\begin{array}{l}\text { Strain } \\
\text { at user } \\
\text { Breatk } \\
\text { imiol }\end{array}$ & $\begin{array}{l}\text { Load } \\
\text { at user } \\
\text { Break } \\
(\mathrm{kN})\end{array}$ \\
\hline 1 & TAI & 2.946 & .7371 & 761.7 & 80030. & 757.60 & .0104 & 738.1 & .0165 & .7143 \\
\hline 2 & TAZ & 2.718 & .659 & 712.9 & 81080. & 452.90 & .0151 & 710.0 & .0151 & .0871 \\
\hline 3 & TAT & 2.642 & .561 & 678.0 & 60520. & 650.90 & .0142 & $0 \longdiv { 5 . 5 }$ & .0147 & . \\
\hline 4 & TAA & 2.769 & .7054 & 730.0 & 84740. & 102.70 & .0154 & 750.1 & .0154 & .7065 \\
\hline 5 & TAS & 3.048 & .773 & 805.5 & e3130. & 139.50 & .0170 & 602.8 & $.017 \dot{v}$ & .770 \\
\hline 6 & $T A B$ & 2.845 & .7251 & 749.3 & 81930. & 193.40 & .0159 & 747.7 & .0159 & .7230 \\
\hline 7 & TAT & 2.896 & .7251 & 749.3 & 81040. & 721.40 & .015 & 748.1 & .0162 & .7037 \\
\hline 8 & TAB & 2.972 & .7562 & 781.4 & 82060. & 732.10 & .0158 & 664.6 & .0160 & .0452 \\
\hline 9 & $|A|$ & 2.946 & .7520 & 777.3 & 22500. & 129.50 & .0165 & 775.9 & .0165 & .7500 \\
\hline \multirow[t]{2}{*}{10} & TAIO & 2.819 & .7237 & 747.9 & 82430. & 90.67 & .0158 & 747.3 & .0157 & .7232 \\
\hline & & & & & & & & & \multicolumn{2}{|c|}{$\therefore$} \\
\hline Men: & & 2.860 & .7249 & 749.1 & 80070. & 398.50 & .0157 & 734.0 & .0100 & .7103 \\
\hline \multicolumn{11}{|l|}{ Stanaard } \\
\hline Deviation: & & $.12 b$ & .0349 & 36.0 & 1362. & 293.10 & .0000 & $42 . v$ & .0007 &.$(44) 7$ \\
\hline Min! uest & & 2.612 & .0501 & 679.0 & $8 \cos 30$ & 98.67 & .0ं142 & 006 & .0147 & . \\
\hline Maxseus: & & 3.048 &.$\pi 75$ & 603.5 & $8474 \%$ & 751.20 & .0170 & BN2.8 & $.0170)$ & .7:-79 \\
\hline
\end{tabular}




\title{
APPENDIX A: INSTRUMENTED MECHANICAL \\ TEST DATA FOR ALL SPECIHEASS
}

\author{
(continued)
}

\author{
LOCNAED HISSILES \& SPACE DO. \\ MATERIALS I PROCESSES ENGINEER!NG \\ DEPT. $79-30$ \\ ¿ Pount Compressive Test-5.1. Units, fian Data
}

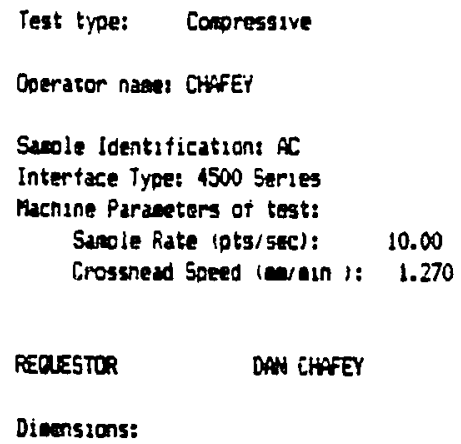

Instron Corporation

Series IX Autconted materiais Testino Srsten $1 . \mathrm{EE}$ Test tate: 03 Feb 1993

Sapie Type: ASTH

Hesedity ( I ): 50

Temerature (dep. F): T3

Out of 10 soreiatens, 0 excluded.

\begin{tabular}{|c|c|c|c|c|c|c|c|c|c|c|}
\hline $\begin{array}{l}\text { Soeci wen } \\
\text { Nusbor }\end{array}$ & ID: & $\begin{array}{l}\text { Dissolcant } \\
\text { at } \\
\text { Bax.Loud } \\
\text { (ea) }\end{array}$ & $\begin{array}{l}\text { Losd } \\
\text { at } \\
\text { Max.Loxd } \\
\text { (KN) }\end{array}$ & $\begin{array}{c}\text { Stress } \\
\text { at } \\
\text { Max.Loed } \\
\text { (KPa) }\end{array}$ & $\begin{array}{l}\text { modulus } \\
\text { (Autroung) } \\
\text { (PP) }\end{array}$ & $\begin{array}{l}\text { Stress } \\
\text { at oftset } \\
\text { Yield I } \\
\text { (Pa) }\end{array}$ & $\begin{array}{l}\text { Strain } \\
\text { at offest } \\
\text { yiseld } 1 \\
\text { (earen) }\end{array}$ & $\begin{array}{l}\text { Stregs } \\
\text { at user } \\
\text { Breex } \\
\text { (IPa) }\end{array}$ & $\begin{array}{c}\text { Strain } \\
\text { at user } \\
\text { Eraak } \\
\text { (mara) }\end{array}$ & $\begin{array}{l}\text { Lowd } \\
\text { at user } \\
\text { Break } \\
\text { IE.NI }\end{array}$ \\
\hline 1 & $A C:$ & 2.819 & .7424 & 786.6 & 00500. & 742.50 & .0158 & 742.5 & .0158 & .7048 \\
\hline 2 & $A C 2$ & 3.073 & .8035 & 851.7 & 88620. & 20.60 & .0171 & 851.4 & .0171 & .86 .36 \\
\hline 3 & $A C Z$ & 2.067 & .6979 & 739.5 & 80120. & 90.50 & .0150 & 738.8 & .0149 & $.69 \pi$ \\
\hline 4 & AC4 & 3.175 & .8243 & 873.3 & 87790. & 11.15 & .0177 & 872.1 & .0176 & .8231 \\
\hline 5 & NCS & 3.231 & .8518 & 902.0 & 88610. & 2.25 & .0181 & 901.0 & .0181 & .8504 \\
\hline$b$ & ADl 1 & 2.845 & .7340 & 799.9 & 87940. & 34.15 & .0150 & 797.0 & .0159 & $.75: 7$ \\
\hline 7 & NE: & 2.972 & .7922 & 839.4 & 88840. & 43.75 & .0160 & 888.6 & .0100 & .7914 \\
\hline 8 & $\cos$ & 2.870 & .7615 & 806.9 & 89480. & 54.73 & .0160 & 805.4 & .0159 & $.76 i j=$ \\
\hline 9 & $A D A$ & 2.845 & .7457 & 788.0 & 86910. & 696.50 & .0159 & 696.3 & .0159 & .0572 \\
\hline 10 & $A 05$ & 3.048 & .8035 & 851.2 & 86970. & 474.10 & .0170 & 850.5 & .0170 & .6027 \\
\hline Mern: & & 2.957 & .7775 & 825. 8 & $\infty 180$. & 219.00 & .0165 & 809.4 & .0165 & .8039 \\
\hline \multicolumn{11}{|l|}{ 5tandard } \\
\hline Deviation: & & .180 & .0457 & 48.4 & 810. & 297.50 & .0010 & 65.8 & .0010 & $.106=1$ \\
\hline Ainsaua: & & 2.667 & .6979 & 739.5 & B6910. & 11.15 & .0150 & 696.3 & .0149 & .6572 \\
\hline Maximua: & & 3.251 & .8518 & 902.6 & 89420. & 742.50 & $.018 !$ & 901.0 & .0181 & $.85 \mathrm{ijt}$ \\
\hline
\end{tabular}




\title{
APPENDIX A: INSTRUMENTED MECHANICAL TEST DATA FOR ALL SPECIMAANS \\ (continued)
}

\author{
LOSIFECD MISSILES $\&$ SPITE CO. \\ WTETIALS \& FROCESTES EMGINEEIITG \\ DEPT. 70-30 \\ ¿ Foint Comoressive iest-s..1. Units. Fam Lata
}

Test troe: Coopressive
Coerator nzee: CHafEi

Sacole Identification: $8 C-0$

intertace iype: 4500 Series

Macnine iaraseters of test:

Sacole fiate totsisecs:

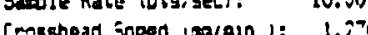

Instren Corporation

Series Ix futonates matertais Testing Jystem 1.,it Test Date: 03 Fed 1993

Sarole Tipe: ASTH

Heasdity ( Z): 50

Teeoerature (deg. F): is

FEQUESTOR

DAY CHFEY

Dimensions:

Spee. 1 Spec. 2 Spec. I Spec. 4 Sper. I Sorc. 6 Soer. 7 Sper. 8

\begin{tabular}{|c|c|c|c|c|c|c|c|c|}
\hline Wroth :en & 12.700 & 12.700 & 12.700 & 12.700 & 12.700 & 12.700 & 12.700 & 12.700 \\
\hline Threxneys (es) & 2.1100 & $2.416 j$ & $2 .+1100$ & $\therefore \$ 100$ & $2.4(1) 9)$ & $\therefore 4100$ & 2.4100 & 2.4100 \\
\hline joec gedọe len ien & 50.800 & $30.2 \times 1$ & 30.800 & 50.800 & 50.300 & 50.800 & 50.200 & 50.800 \\
\hline (⿻心) & 101.001 & $101 . \infty)$ & lut.a) & 101.60 & 101.00 & 101.00 & 101.60 & 1.60 \\
\hline
\end{tabular}

Out af liv soecinans. is exciuard.

\begin{tabular}{|c|c|c|c|c|c|c|c|c|c|c|}
\hline $\begin{array}{l}\text { Soecisen } \\
\text { number }\end{array}$ & t2: & $\begin{array}{l}\text { Oasolcant } \\
\text { at } \\
\text { hax.Load } \\
\text { (ma) }\end{array}$ & $\begin{array}{l}\text { Load } \\
\text { at } \\
\text { Max.Loso } \\
\text { (IN) }\end{array}$ & $\begin{array}{c}\text { Stress } \\
\text { at } \\
\text { Max.Lond } \\
\left(\text { Pra }_{3}\right)\end{array}$ & 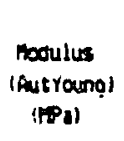 & $\begin{array}{l}\text { Stress } \\
\text { at ot foet } \\
\text { rield I } \\
\text { (IPa) }\end{array}$ & $\begin{array}{l}\text { Strain } \\
\text { at offeset } \\
\text { rield } 1 \\
\text { (amans }\end{array}$ & $\begin{array}{l}\text { Stress } \\
\text { at user } \\
\text { Brtak } \\
\text { (FPa) }\end{array}$ & $\begin{array}{c}\text { Straln } \\
\text { dt user } \\
\text { Break } \\
\text { Ieoiem) }\end{array}$ & $\begin{array}{c}\text { Load } \\
\text { 3t user } \\
\text { Break } \\
\text { (KN) }\end{array}$ \\
\hline 1 & $\mathrm{BCl}$ & $2.00 i$ & .7075 & 736.7 & 87420 & 042.10 & .0149 & 042.1 & .0149 & $.616=$ \\
\hline 2 & $B C 2$ & 2.743 & .7509 & 782.4 & 88630 . & $98 . \infty 8$ & .0154 & 779.9 & .0153 & .7495 \\
\hline I & $B C 3$ & 2.817 & .7486 & 780.0 & 8180. & 350.20 & .0157 & $\pi 7.1$ & .0157 & 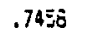 \\
\hline 4 & EC4 & 2.743 & .7571 & 768.0 & 67390. & 596.90 & .0120 & 766.7 & .0152 & .7558 \\
\hline 5 & $5 x$ & 2.769 & .7517 & 7QD.: & 87910. & 603.30 & .0153 & 782.1 & .0155 & $.550 \mathrm{c}$ \\
\hline$b$ & $\mathrm{BDL}$ & 2.067 & .7104 & 740.2 & 05290 . & 166.40 & .0149 & 739.1 & .0148 & 5755 \\
\hline 7 & 802 & 2.565 & .6852 & 711.9 & 80950. & 152.50 & .0143 & 709.7 & .0142 & .5811 \\
\hline$\theta$ & $B 003$ & 2.921 & .7734 & 811.1 & 88550. & 272.20 & .0163 & 610.3 & .0163 &.$\pi$ \\
\hline 9 & BDA & 2.672 & $.234 t$ & 735.1 & (1). & 164.20 & .0151 & 734.5 & .0150 & $.724:$ \\
\hline 10 & BnS & 2.540 & .0215 & 710.1 & 85isos. & 280.90 & .0141 & 700.9 & .0141 & .0834 \\
\hline Mean: & & 2.715 &.$T 274$ & 57.7 & 87950. & 328.70 & .0140 & 747.0 & .0151 & . 7174 \\
\hline $\begin{array}{l}\text { Stanoard } \\
\text { Deviatione }\end{array}$ & & .113 & .0317 & 3.4 & 1120 & 209.70 & .0012 & 49.0 & .0000 & . \\
\hline Miniouss & & $2.54 i j$ & .0ة15 & 710.1 & 60100. & 78.68 & .0120 & 842.1 & .0141 & .6102 \\
\hline Maxioun: & & 2.921 & .7 .34 & 811.1 & BFS50. & 042.10 & .0103 & $810 . ?$ & ن̈ا & $.7 ?$ \\
\hline
\end{tabular}




\section{APPENDIX A: INSTRUMENTED MECHANICAL}

\section{TEST DATA FOR ALL SPECIMENS}

\section{(continued)}

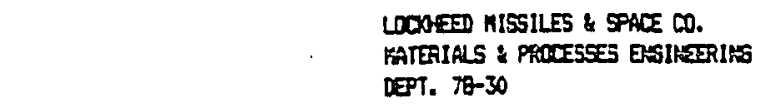

3 Point Cosonressive Test-S.L. Lnits, Riza Data

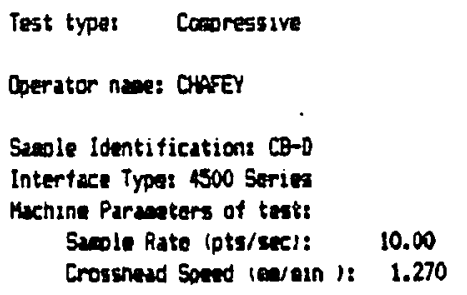

Out of :0 specimens. 0 excluoso.

\begin{tabular}{|c|c|c|c|c|c|c|c|c|c|c|}
\hline $\begin{array}{l}\text { Joecinom } \\
\text { fonder }\end{array}$ & 101 & $\begin{array}{l}D i \equiv E: C \cos t \\
\text { at } \\
\max \cdot \text { Losd } \\
(\log )\end{array}$ & $\begin{array}{l}\text { Leso } \\
\text { at } \\
\text { Max.Lax } \\
\text { (xas) }\end{array}$ & $\begin{array}{c}\text { Stress } \\
\text { at } \\
\text { Max.Lox } \\
\text { (1rod) }\end{array}$ & 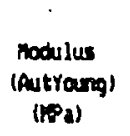 & $\begin{array}{l}\text { Stress } \\
\text { at of fest } \\
\text { yineld I } \\
\text { (100a) }\end{array}$ & $\begin{array}{l}\text { Strain } \\
\text { at oftset } \\
\text { Yinid } 1 \\
\text { (ealon }\end{array}$ & $\begin{array}{l}\text { Stress } \\
\text { at user } \\
\text { Brastu } \\
\text { (1Pa) }\end{array}$ & $\begin{array}{l}\text { Strain } \\
\text { at user } \\
\text { Bredk } \\
\text { (eoseal }\end{array}$ & 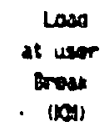 \\
\hline 1 & $\boldsymbol{x I}_{1}$ & 2.896 & .7442 & 785.2 & 83690. & 162.80 & .0162 & 782.6 & .0162 & .7410 \\
\hline 2 & 0.2 & 2.769 & .7042 & 792.9 & E\$010. & 154.60 & .0155 & 792.4 & .0155 & .70330 \\
\hline 3 & $a x$ & 2.565 & .6521 & 666.9 & B1E30. & 192.50 & .0143 & 665.7 & .0143 & .0209 \\
\hline 4 & $\infty 4$ & 2.921 & .7469 & 788.0 & 60640 . & 110.40 & .0163 & 787.3 & .0163 & .742 \\
\hline 5 & $\cos$ & 2.616 & .6797 & 717.1 & 86900. & 218.90 & .0147 & 715.1 & .0146 & $.6 \pi 78$ \\
\hline 6 & $\infty$ & 2.845 & .7313 & 771.6 & 88850. & 101.90 & .0199 & 769.5 & .0159 & .7293 \\
\hline 7 & $c 02$ & 2.997 & .7611 & 803.0 & Q299\$0. & 57.32 & .0167 & 001.4 & .0100 & .7576 \\
\hline 8 & 003 & 2.499 & .6268 & 61.3 & 83430. & 240.40 & .0139 & $\Delta \rightarrow .8$ & .0139 & .6204 \\
\hline 9 & cos & 2.794 & .7211 & 760.8 & 80870. & 729.30 & .0156 & 729.3 & .0156 & .0912 \\
\hline 10 & 0106 & 2.642 & .6961 & 734.5 & 86060 . & 158.10 & .0149 & 752.7 & .0148 & .0949 \\
\hline $\operatorname{man}$ & & 2.753 & .7043 & 743.1 & 64700. & 214.60 & .0154 & 738.6 & .0154 & .7000 \\
\hline $\begin{array}{l}\text { Starioard } \\
\text { Deviations }\end{array}$ & & .168 & .0460 & 49.2 & 1749. & 190.10 & .0008 & 49.8 & .0009 & .0452 \\
\hline Hintaess & & 2.489 & .6268 & $\omega 1.3$ & 81850. , & 57.52 & .0139 & 659.8 & .0139 & .6294 \\
\hline Max1eua: & & 2.997 & .7611 & 063.0 & 86900. & 729.30 & .0167 & 801.4 & .0166 & $.75=0$ \\
\hline
\end{tabular}




\title{
APPENDIX A: INSTRUMENTED MECHANICAL TEST DATA FOR ALL SPECIRENS \\ (continued)
}

\author{
LOCKHEED KISSILES \& SPACE CO. \\ MATERIALS \& FROCESSES ENGINESTING \\ DEFT. $75-30$
}

Z Foint ionoressive Test-j. I. Units, Rat iata

\author{
Test type: Coeoressive \\ Ooerator nase: CHAFE
}

Sacose Identification: $C C-0$

Intertace Type: 4500 Series

Machine farapeters of tast:

Sanole Fate iptsiser: $\quad 10.00$
Instron Corooration

Series Ix mutouted materials iesting S stan $1 . .0$ Test Date: if fed 100?

Suale rypes NSTH

Huasasty 1 \% 1: 50

Teoperature (deg. Fl: 73

REDLESTOR DAN CHAFEY

Dieensigns:

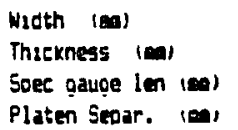

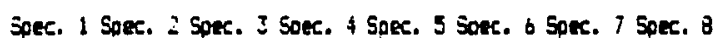

$\begin{array}{llllllll}12.700 & 12.700 & 12.700 & 12.700 & 12.700 & 12.700 & 12.700 & 12.700\end{array}$ $\begin{array}{llllllll}2.45 i 0 j & 2.4500 & 2.4500 & 2.4500 & 2.4500 & 2.4500 & 2.4500 & 2.4500\end{array}$ $\begin{array}{lllllllll}50.600 & 50.800 & 50.800 & 50.800 & 50.800 & 50.800 & 50.800 & 50.800 !\end{array}$

$101.60 \quad 101.00 \quad 101.60 \quad 101.60101 .00101 .00101 .001001 .00$

Out of 10 soecisens, Excluded.

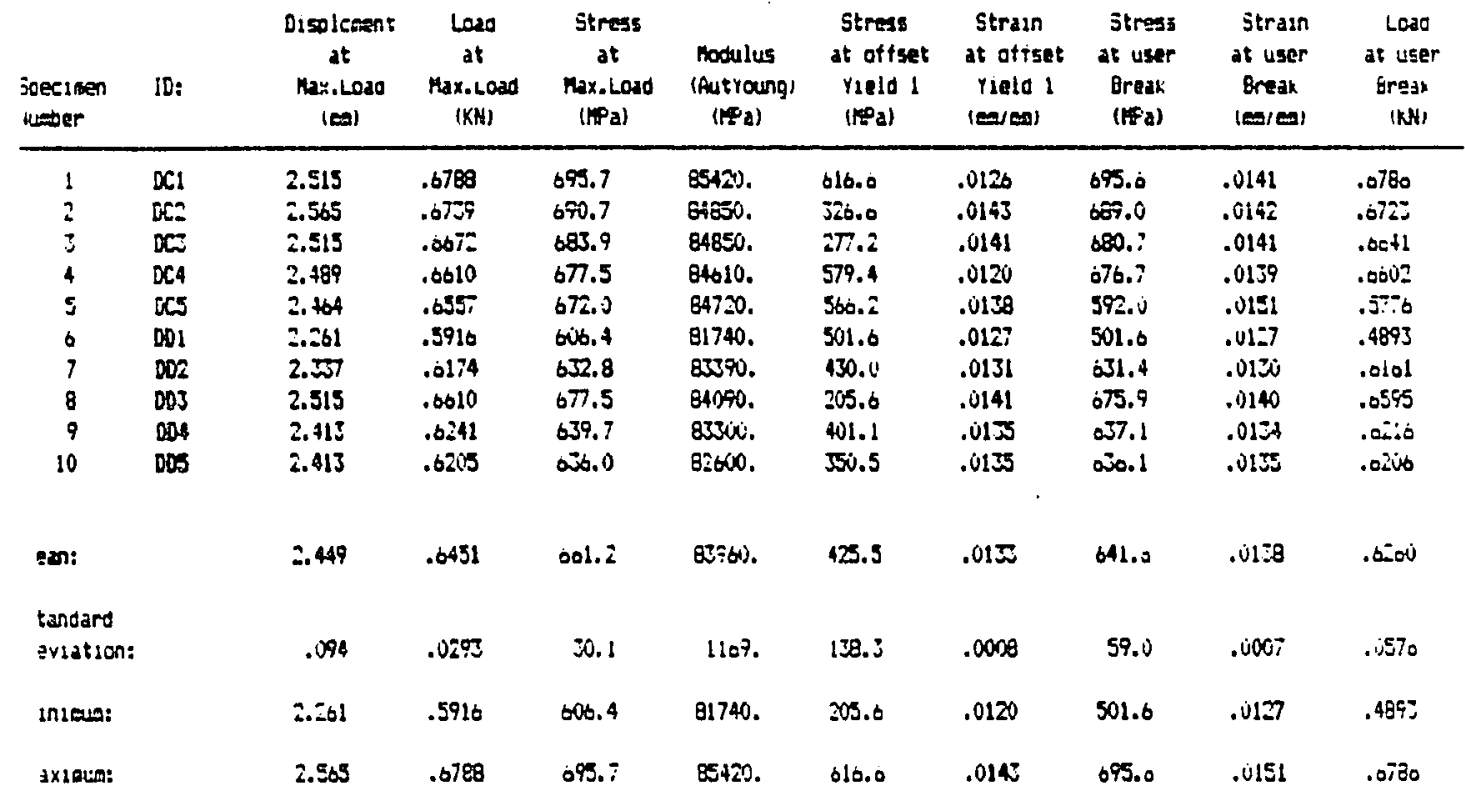




\title{
APPENDIX A: INSTRUEENTED HECHANICAL \\ TEST DATA FOR ALL SPECIAENS
}

(continued)

\author{
LOAHEE MISEILES $:$ SPACE CO.

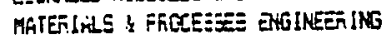 \\ DEFT. TE-jo \\ : Folnt Cocoressive Test-j.i. Inits. Faw Data
}

Test tipe: ioaoressive
Soerator nape: CHafer

Eaecie Ldentification: Ei-b

Interrace Tyce: 4500 jeries

Macnine Faramaters or test:

$$
\begin{aligned}
& \text { Sanole iate roeg/seci: } 10 . \dot{v 0} \\
& \text { irosinead joeed learein :: 1.270 }
\end{aligned}
$$

Instren Eorooration

Series IX furdeated Materials iesting Evstem 1.:0 Test Uate: of Fet IOF $^{2}$

Sucole Type: istrt

Heresesty 1: 1: 50

Tewerature iagg. Fi: $Z$

EEXEGTUR DNW IHFEI

Eivensions:

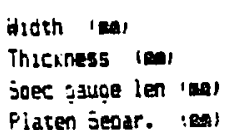

Soec. I joec. 2 joec. : Soec. + Soec. I soec. o Sore. I Spec. 8

$\begin{array}{llllllll}12.700 & 12.700 & 12.700 & 12.700 & 12.700 & 12.700 & 12.700 & 12.760\end{array}$

$\begin{array}{llllllll}2.34(0) & 2.3400 & 2.3400 & 2.3400 & 2.3400 & 2.3400 & 2.3400 & 2.3400\end{array}$

$\begin{array}{lllllllllll}50.800 & 50.800 & 50.800 & 50.800 & 50.800 & 50.800 & 50.800 & 50.800\end{array}$

$101.00101 .00 \quad 101.00,101.00101 .00101 .00101 .001101 .601$

\begin{tabular}{|c|c|c|c|c|c|c|c|c|c|c|}
\hline $\begin{array}{l}\text { Soecinen } \\
\text { hurper }\end{array}$ & ID: & 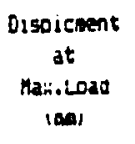 & $\begin{array}{l}\text { Load } \\
\text { at } \\
\text { Max.Load } \\
\text { (KN) }\end{array}$ & $\begin{array}{l}\text { Stress } \\
\text { at } \\
\text { Hax.Load } \\
\text { (Mal }\end{array}$ & $\begin{array}{l}\text { Modulus } \\
\text { (Autroung) } \\
\text { (IPa) }\end{array}$ & $\begin{array}{l}\text { Stress } \\
\text { at offest } \\
\text { yield } 1 \\
\text { (YPa) }\end{array}$ & $\begin{array}{l}\text { Strain } \\
\text { at oftset } \\
\text { Yieid } 1 \\
1 \mathrm{ma} / \mathrm{mol}\end{array}$ & $\begin{array}{l}\text { Stress } \\
\text { at user } \\
\text { Break. } \\
\text { (fFal }\end{array}$ & $\begin{array}{c}\text { Stra!n } \\
\text { at user } \\
\text { Break } \\
\text { (anos }\end{array}$ & $\begin{array}{l}\text { Load } \\
\text { at User } \\
\text { Ereak } \\
\text { (Y.S\} }\end{array}$ \\
\hline 1 & Ei: & 2.597 & .7179 & 770.4 & 82040. & 21.02 & .0167 & 768.0 & $.010^{-}$ & $.715:$ \\
\hline 2 & EE? & 3.079 & .7718 & 928.2 & 84530. & 36.95 & .0173 & 825.7 & .0173 & .7204 \\
\hline$:$ & EST & ${ }_{3}^{3.4448}$ & .7571 & 812.4 & 84070. & 34.31 & .0171 & 811.6 & 40.48. & .505 \\
\hline 4 & EEA & 3.109 & .7749 & 831.5 & 84570. & 41.74 & .0173 & 200.9 & $.01 \pi$ & .7934 \\
\hline 5 & E[S & 3.67 & .7634 & 818.2 & 84580. & 25.38 & .0171 & 817.t & .0171 & .7017 \\
\hline - & EDI & $\therefore .3 N$ & .7718 & 829.2 & 8204ij. & 815.70 & .0170 & 827.2 & .0178 & . \\
\hline$i$ & EF: & 2.972 & $.748:$ & 802.7 & essious. & 19.00 & .0100 & 802.4 & . Otico & $.747^{\circ}$ \\
\hline 8 & E33 & 2.740 & $.74 \%$ & 750.2 & $854 \%$. & J.00 & .0165 & 794.8 & .0165 & $\therefore$ alice \\
\hline 7 & ENA & $3.15 i$ & . & 855.4 & 84830. & 31.15 & .0170 & 854.7 & . U176 & .7905 \\
\hline 10 & EDS & $\therefore .277$ & .9247 & 805.0 & 85150. & 809.70 & .0180 & 884.6 & .0183 & $E=4 ;$ \\
\hline Hean: & & $3.08 b$ & . & 822.7 & 84420 & 193.30 & .0172 & 821.6 & .0175 & .7050 \\
\hline $\begin{array}{l}\text { Standard } \\
\text { Gev:ation: }\end{array}$ & & .103 & $.0=99$ & 31.7 & 1200. & 312.00 & . i00s & 52.1 & . vijo & $.0=99$ \\
\hline Hinzoum: & & 2.946 & $\therefore 179$ & 770.4 & 82040. & 19.60 & .0165 & 768.0 & .0165 & .7157 \\
\hline Ma:1 qua: & & 3.378 & $.8 i \neq 7$ & 895.; & Esirs. & 869.70 & $.016\rangle$ & 884.0 & . vlaz & $.824:$ \\
\hline
\end{tabular}

Dut of lis soeeswens. is exciudeed. 


\title{
APPENDIX A: INSTRUMENTED MECHANICAL TEST DATA FOR ALL SPECIMENS \\ (continued)
}

\author{
LOCH HEEI MISSTILE \& FFHEE CO.

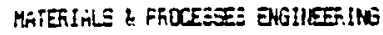 \\ IEFT. IQ-iv

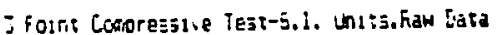

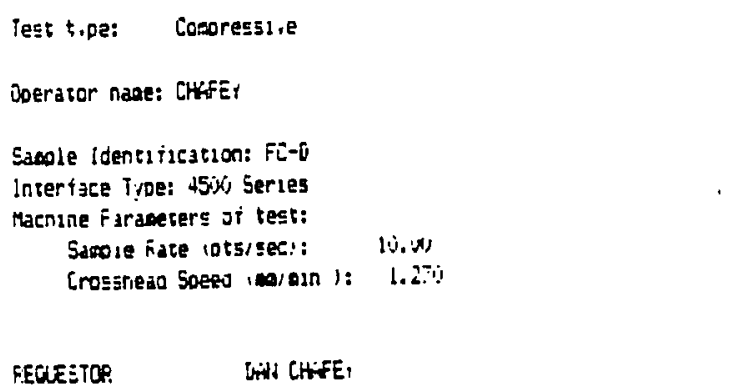

Instron Corsoration

Serles Ix Autosated Materials Testung Systen i, wo

Test Date: if reg 1993

Susole iype: ASTM

Heandsty : : : 5 S

Tenoerature ldeq. F:

Cieensions:

Width (ea)
Thicknesz (ea)
joec paguge ien ias
flaten jepar. Ial

Eorc. I Spec. I Soec. : Spec. 4 Snec. 5 Spec. D Soec. I Soec. I

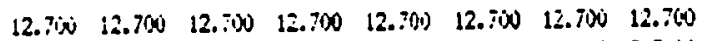

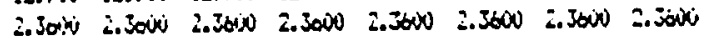

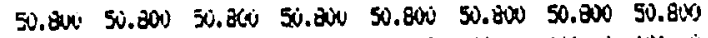

101.00 101.00 101.00 101.00 101.00101 .00101 .00101 .00

Out of 11 specimens. is exciudes.

\begin{tabular}{|c|c|c|c|c|c|c|c|c|c|c|}
\hline $\begin{array}{l}\text { Eoeclinen } \\
\text { huroer }\end{array}$ & ID: & $\begin{array}{l}\text { U1solcoent } \\
\text { at } \\
\text { Max.Load } \\
1001\end{array}$ & $\begin{array}{c}\text { Lowo } \\
\text { at } \\
\text { Mdin.Load } \\
\text { (KN) }\end{array}$ & $\begin{array}{l}\text { Stress } \\
\text { at } \\
\text { Max.Lozo } \\
\text { !ral }\end{array}$ & $\begin{array}{l}\text { Modulus } \\
\text { (Autroung) } \\
\text { (tf s) }\end{array}$ & $\begin{array}{l}\text { Stross } \\
\text { at offset } \\
\text { nelo } 1 \\
\text { 16ral }\end{array}$ & $\begin{array}{l}\text { Strain } \\
\text { at offset } \\
\text { icelo I } \\
\text { Imieal }\end{array}$ & $\begin{array}{l}\text { Stress } \\
\text { at ueer } \\
\text { Ereak } \\
\text { (pipal }\end{array}$ & $\begin{array}{l}\text { Straun } \\
\text { at uger } \\
\text { Break. } \\
\text { (Renias) }\end{array}$ & $\begin{array}{l}\text { Loado } \\
\text { at 'user } \\
\text { Ergak } \\
\text { IRfil }\end{array}$ \\
\hline 1 & $\mathrm{FCl}$ & 2.551 & .0441 & ': & 228ij. & 145. ivi & .0145 & 62.5 & .0144 & .0428 \\
\hline$\Sigma$ & $F_{i i}$ & $\therefore .464$ & $.01+i$ & 0.54 .1 & 24020. & 072.40 & .0137 & 036.4 & .0137 & oivis \\
\hline$j$ & $F[\bar{Z}$ & 2.571 & .0495 & 571.5 & Esliv. & 240.80 & .0145 & $069 . i$ & .0144 & . \\
\hline 4 & FCt & 2.616 & . odva & 702.9 & E3570. & 161.00 & .0147 & 700.2 & .0146 & .0581 \\
\hline$\Xi$ & FE' & i.olo & .0028 & 905.2 & BA65ij. & $312 . a \dot{v}$ & .0145 & 704.8 & .0145 &.$\infty 0^{\circ}$ \\
\hline 0 & $\mathrm{Fb!}$ & 2.546 & $.743 i$ & $; \% 1.4$ & $8505 i$. & 71.47 & .0164 & 790.4 & .016i & .7 .75 \\
\hline 7 & FD: & 2.718 & . & 724.0 & 8498:. & 117.30 & .0152 & 722.9 & .0152 & $.67=4$ \\
\hline 8 & F:3 & $2.87 \mathrm{v}$ & .7382 & 774.8 & 86130. & IE2.40 & .0161 & $\pi 2.7$ & .0160 & .7202 \\
\hline 7 & FO4 & 2.940 & .7455 & $7<7.5$ & 8553. & .3 .110 & .0164 & $79 \% .0$ & .0164 & $.74=1$ \\
\hline 10 & Fos & $\therefore .754$ & . ilos & $: b=.5$ & 65490. & $173.7 \mathrm{i}$ & . 1150 & 761.0 & .0150 & PiE: \\
\hline Mean: & & 2.715 & .0551 & ?29. & 34850. & $313.0 \mathrm{v}$ & .0152 & 725.1 & . i)15: & . veEt \\
\hline $\begin{array}{l}\text { St andard } \\
\text { Deriaticn: }\end{array}$ & & .18 & .4405 & 49.4 & tings. & 100.30 & . Uंrsa & $52 .:$ & $.000^{\circ}$ & $\therefore 4=1$ \\
\hline Minıoun: & & $\therefore 407$ & .0147 & 054.1 & a2äiv. & $71.4 ?$ & . & 039.4 & ה1517 & . \\
\hline Ma.toun: & & $\therefore .946$ & .7475 & 797.5 & Bo!:00. & 6.38 .10 & .0104 & 797.15 & .0164 & $.74=!$ \\
\hline
\end{tabular}




\title{
APPENDIX A: IASTRUMENTED MECHANICAL \\ TEST DATA FOR ALL SPECIMENS
}

(continued)

\author{
WONED MISSILES \& SACE \\ FATERIALS : FROCESSES BWIIVERITE \\ DEPT. $78-30$
}

3 Point Compressive Test-S.I. Units, fian Data

Test type: Compressive

Doerator naces: Chafey

Sascle Identification: $x C-D$

Intertace Type: 4500 Series

Huchine Paraoeters of test:

Suole Rate (pts/sec): $\quad 10.00$

Crosshead soesd leavain it 1.270
Instron Corporation

Series IX putonated materials Testing System 1.08 Test Dater of Feb 1993

Suple Types ASTH

Nendity $(8)$ so

Temperature (dang. F): $T 3$
PEAESTOR . DAN CHFEY

Diamsionsi

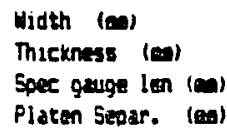

Spec. 1 Sper. 2 sper. 3 Spec. 1 Sorc. 5 spec. 6 Spec. 7 Spec. I

$\begin{array}{llllllll}12.700 & 12.700 & 12.700 & 12.700 & 12.700 & 12.700 & 12.700 & 12.700\end{array}$

$\begin{array}{llllllll}2.4100 & 2.4100 & 2.4100 & 2.4100 & 2.4100 & 2.4100 & 2.4100 & 2.4100\end{array}$

$\begin{array}{lllllllllllll}50.800 & 50.800 & 50.800 & 50.800 & 50.800 & 50.800 & 50.800 & 50.800\end{array}$

$101.60101 .60101 .60 \quad 101.60101 .60 \quad 101.60101 .60101 .60$

Out of 10 soecraens. 0 excluder.

\begin{tabular}{|c|c|c|c|c|c|c|c|c|c|c|}
\hline $\begin{array}{l}\text { Specisen } \\
\text { nuster }\end{array}$ & ID: & $\begin{array}{c}\text { Displcaent } \\
\text { at } \\
\text { Kax.Lasd } \\
\text { (as) }\end{array}$ & $\begin{array}{l}\text { Losd } \\
\text { at } \\
\text { Max.Lowd } \\
\text { (W.) }\end{array}$ & $\begin{array}{l}\text { Streas } \\
\text { at } \\
\text { Max.low } \\
\text { (Pra) }\end{array}$ & $\begin{array}{l}\text { Podulus } \\
\text { (Autrang) } \\
\text { (Pa) }\end{array}$ & $\begin{array}{l}\text { Streess } \\
\text { at offeet } \\
\text { Yiuld I } \\
\text { (IPa) }\end{array}$ & $\begin{array}{l}\text { Stram } \\
\text { at offert } \\
\text { Yield I } \\
(a, \infty)\end{array}$ & $\begin{array}{l}\text { Stress } \\
\text { at user } \\
\text { Break } \\
\text { (IPa) }\end{array}$ & $\begin{array}{l}\text { Strain } \\
\text { at user } \\
\text { Break } \\
\text { (mai mal }\end{array}$ & $\begin{array}{l}\text { Load } \\
\text { at usser } \\
\text { Break } \\
(\mathrm{KN})\end{array}$ \\
\hline 1 & EI & 2.413 & .6081 & 653.6 & 81110. & $2 \pi 7.4$ & .0135 & 631.6 & .0135 & .6061 \\
\hline 2 & 2 & 2.093 & .5342 & 55.6 & $\cos 9$. & 290.0 & .0117 & Es.7 & .0116 & .5324 \\
\hline 3 & $\cos$ & 2.235 & .5671 & 590.9 & 82830. & 139.6 & .0125 & 567.8 & .0124 & .5642 \\
\hline 4 & Exh & 2.362 & .6041 & 629.4 & 820200. & 162.4 & .0152 & 628.0 & .0132 & .6035 \\
\hline 5 & 00 & 2.362 & .6072 & 652.7 & 8000. & 528.8 & .0132 & 52.8 & .0152 & .5506 \\
\hline 6 & $\theta 1$ & 2.37 & .5916 & 616.4 & E0ะ0. & 259.4 & .0131 & 614.4 & .0130 & .5897 \\
\hline 7 & 602 & 2.456 & .6219 & 640 & 25iso. & 179.3 & .015 & oto.: : & $\therefore:=$ & .02002 \\
\hline 8 & $\cos$ & 2.616 & .6721 & 700.3 & $80 \% 0$. & 172.2 & . vito & $6 i 5.8$ & .0140 & .0706 \\
\hline 9 & Ei4 & 2.413 & .6076 & ! & do:-3. & 184.0 & .0134 & as.6 & .0154 & .6071 \\
\hline$: 0$ & $3 x$ & $\therefore 3 E:$ &.$\$ 743$ & 019.2 & ald10. & 219.4 & $.0132^{\circ}$ & 617.4 & $.01: 1$ & S?: \\
\hline $\mathrm{r}_{4 \mathrm{i}: \mathrm{:}}$ & & 2.30" & .6000 & 620.0 & E46. & 243.7 & .0135 & alte.s & $.01:=$, & $.5 \div ! 7$ \\
\hline \multicolumn{11}{|l|}{ Standard } \\
\hline Deviation: & & .138 & .10355 & 37.0 & 115. & 118.9 & .0100 & 42.4 & .0018 & $.441 ?$ \\
\hline Finimus: & & 2.063 & .5342 & 550.0 & Busar. & 139.0 & .0117 & 552.8 & .0110 & \\
\hline Ma::1euns: & & 2.016 & .0.:21 & : & 2520. & 552.8 & .0146 & 698.8 & .0140 & .6700 \\
\hline
\end{tabular}




\title{
APPENDIX A: INSTRUMENTED MECHANICAL TEST DATA FOR ALL SPECIMENS
}

\section{(continued)}

\author{
LOCH HES MISSILES : SPACE M. \\ MATEFITLS \& FROCEEEES PRGINEE ING \\ LEFT. $78-30$
}

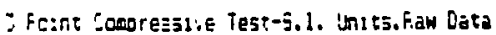

iest :;ce: Coopresenve

Coerator nase: CHHFEY

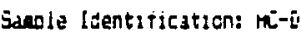

interrace Tyoe: 45 in jertes

Macnune farmesers or test:

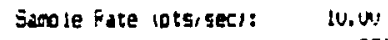

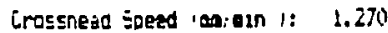

Instron Lorscration

Series ik turtoeated Materials iesting justem 1.05 Test iste: Wot Fet 190?

Sanole Type: risip

Huadesty i: :s sit

Tesperature ideq. F:: TE

FEUAETIOF TH CHSFEt

Dieterszons:

\begin{tabular}{|c|c|c|c|c|c|c|c|c|}
\hline Wiath & $12 . .00$ & 12.700 & $12.0 \%$ & 12.000 & 12.700 & 12.700 & 12.700 & 12.700 \\
\hline Thicrnef: (ent) & $\begin{array}{l}2.4000 \\
50.800\end{array}$ & $\begin{array}{l}2.4600 \\
30.800\end{array}$ & $\begin{array}{l}\therefore+H(w) \\
50.80 x\end{array}$ & $\begin{array}{l}2 .+1600 \\
50.800\end{array}$ & 2.4600 & $2 .+6 \sin$ & $\begin{array}{l}2.4600 \\
50.800\end{array}$ & $\begin{array}{l}2 .+6000 \\
3 j .80 i j\end{array}$ \\
\hline (n) & 101.50 & 101.50 & 101.01 & 101.00 & 101.00 & נúl.o' & 101.00 & $101.01)$ \\
\hline
\end{tabular}

Int of liv soecinens. "y eacluapo.

\begin{tabular}{|c|c|c|c|c|c|c|c|c|c|c|}
\hline $\begin{array}{l}\text { Soes:isen } \\
\text { Huster }\end{array}$ & IE: & $\begin{array}{c}\text { Di=0ledent } \\
\text { at } \\
\text { (aid }\end{array}$ & $\begin{array}{c}\text { Lodo } \\
\text { at } \\
\text { Max:.Load } \\
(t . M)\end{array}$ & $\begin{array}{l}\text { Stress } \\
\text { at } \\
\text { Hax.Loso } \\
\text { (iffa) }\end{array}$ & $\begin{array}{l}\text { Mootulus } \\
\text { (Autroung) } \\
\text { (1fo) }\end{array}$ & $\begin{array}{l}\text { Stress } \\
\text { at offsat } \\
\text { reld } 1 \\
\text { infal }\end{array}$ & 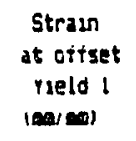 & $\begin{array}{c}\text { Stress } \\
\text { at user } \\
\text { Breax } \\
\text { (IP2) }\end{array}$ & $\begin{array}{c}\text { Strass } \\
\text { at user } \\
\text { Breis } \\
\text { (amion) }\end{array}$ & $\begin{array}{l}\text { Lod: } \\
\text { dt -ser } \\
\text { Bres: } \\
\text { iN) }\end{array}$ \\
\hline 1 & $\times 1$ & 2. tot & Lis. & 081.1 & BoiTo. & 448.6 & .0151 & 678.: & .0150 &.$\infty \Delta d$ \\
\hline 2 & $\mathrm{HC2}$ & 2.357 & .0343 & 447.5 & 86070. & $268 . j$ & . نे131 & $6+6.9$ & . v131 & ת: \\
\hline Z & $\mid I^{\prime}$ & $2 .+13$ & .0010 & 674.7 & 8720. & 190.5 & S.015 & bil.s & .013 & ד:-80. \\
\hline 4 & HA & $\therefore$ ¿.261 & .0179 & 029.8 & B771u. & 352.8 & . 0120 & 038.0 & 650.01. &.$=156$ \\
\hline 5 & HCS & 2.37 & 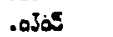 & 049.8 & $8725 j$. & 283.0 & .0131 & $\Delta 47 . j$ & : & jor. \\
\hline 6 & 101 & 2.738 & .0423 & 655.? & Eogix). & 209.2 & .0136 & क. & .0105 & $.0+23$ \\
\hline$?$ & Hoi & $\therefore .50$ & . & 689.3 & boosi. & 130.2 & .0142 & 687.0 & .0141 & $0 \% 0$ \\
\hline 8 & 403 & 3.464 & .6574 & 071.1 & Estor), & 378.2 & .0153 & a 70.2 & .0137 & .0500 \\
\hline 7 & Find & 2.69 & $.0 / 35$ & 687.5 & 87020 & 259.3 & .0139 & 686.0 & $.015:$ & s:: \\
\hline 10 & Hos & 2.389 & .0552 & 040.4 & ES440. & 357.4 & .0133 & 646.8 & .0102 & . \\
\hline Mean: & & 2.413 & $.050 j$ & 003.5 & $B \in T S \dot{0}$. & 285.8 & .0235 & Ebl.o & .0154 & 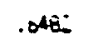 \\
\hline $\begin{array}{l}\text { jtandaro } \\
\text { Deviation: }\end{array}$ & & .084 & .01196 & 20.0 & 874. & 95.7 & ك.000s. & 19.8 & . vWoje & $\ldots 174$ \\
\hline Mun:sun: & & 2.zal & .6170 & $6: 9.8$ & 25400. & 130.2 & .0126 & ¿28.6 & . & 15.0.8. \\
\hline Maxioum: & & 2.54 ) & .0752 & 689.5 & $8773 j$. & 448.8 & .0142 & 687.0 & .0141 & $.0 .=$ \\
\hline
\end{tabular}




\title{
APPENDIX A: INSTRUMENTED MECHANICAL \\ TEST DATA FOR ALL SPECIMENS \\ (continued)
}

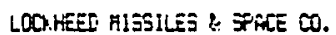

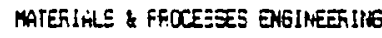 \\ DEFT. ?E-30 \\ ¿ ferrt Somorestive iest-j.l. units.ina Lasa
}

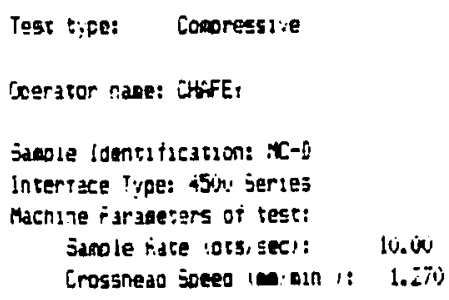

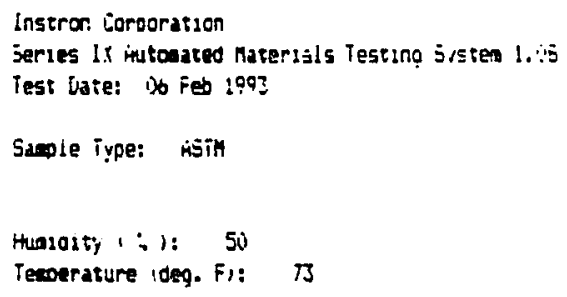

Out at li इpeciaens, " exchuoed.

\begin{tabular}{|c|c|c|c|c|c|c|c|c|c|c|}
\hline $\begin{array}{l}\text { soecion } \\
\text { inumper }\end{array}$ & tD: & $\begin{array}{c}\text { Disol ceant } \\
\text { at } \\
\text { Mar.cosd } \\
\text {. }\end{array}$ & $\begin{array}{c}\text { Losd } \\
\text { al } \\
\text { Fax.Lax } \\
\text { (kN) }\end{array}$ & $\begin{array}{l}\text { Stress } \\
\text { at } \\
\text { Max.Load } \\
\text { (HFa) }\end{array}$ & $\begin{array}{l}\text { nooulus } \\
\text { (Rutroungl } \\
\text { IPPa) }\end{array}$ & $\begin{array}{l}\text { Stregs } \\
\text { at offent } \\
\text { yeid I } \\
\text { (IFral }\end{array}$ & $\begin{array}{l}\text { Straun } \\
\text { at oirset } \\
\text { rielo } 1 \\
\text { imial }\end{array}$ & $\begin{array}{l}\text { Stress } \\
\text { at user } \\
\text { Breas } \\
\text { (Fifal }\end{array}$ & $\begin{array}{c}\text { Strain } \\
\text { et user } \\
\text { Brakx } \\
\text { ina / ag }\end{array}$ & $\begin{array}{l}\text { Lose } \\
\text { at user } \\
\text { srea" } \\
\text { (llu }\end{array}$ \\
\hline 1 & $\mathrm{KI}$ & $\therefore \dot{\theta}$ & .0019 & 710.3 & 8480. & 310.40 & . & 709.8 & .0149 & $.001 t$ \\
\hline$\vdots$ & $x_{2}$ & 2.743 & .0984 & 749.4 & 50450. & 10.20 & . ن154 & 747.7 & . 0153 & .0905 \\
\hline ; & $\mathrm{KC}$ & $5.97 \%$ & .7385 & 792. & 84750. & 25.34 & olsion. & 791.2 & .0105 & ; \\
\hline 4 & $\mathrm{HCA}$ & $\therefore .46 t$ & .067 & 654.4 & 837iv. & 111.80 & .0137 & 65.7 & .0137 & . OUEZ \\
\hline 5 & nos & 2.771 & .0825 & $i 32 . i$ & eslix. & ذ. ن. & $.015 i$ & $T$ TS. 0 & .0156 & .0821 \\
\hline j & ntor & i.87i & .2117 & 703.8 & 84000 . & 297.70 & . Jlal & 701.5 & .0100 & .010 \\
\hline$\cdot$ & $\nabla_{i}$ & $2 . .94$ & .050 & 750.0 & Eotai. & 422.30 & .0156 & 754.4 & . & 0000 \\
\hline a & 103 & 3.023 & $.47 \pi$ & $80 \% .4$ & EA2bU. & 47.26 & .0169 & 801.1 & .0109 & .7465 \\
\hline 9 & 124 & 2.890 & 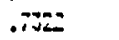 & 785.: & $854+0$. & $29 . \ddot{0}$ & .0102 & 782.0 & .0161 & 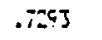 \\
\hline 10 & vas & 2.591 & .0441 & 691.2 & 82210. & 76.83 & .0149 & 089.0 & . 1145 & .0423 \\
\hline Mean: & & 2.751 & .095 & 743.7 & 84560. & 15.20 & .0150 & 782.2 & .0155 & ع \\
\hline \multicolumn{11}{|l|}{ Etanoaro } \\
\hline Deviation: & & .172 & $.044 !$ & 47.4 & L419. & 149.90 & .0010 & $47 .:$ & .0010 & .0440 \\
\hline Minisua: & & $=.764$ & .0099 & 654.4 & B2siv. & 10.20 & .0157 & 652.7 & .0157 & .tigs \\
\hline Ma:c1 eus: & & $\dot{S}_{4} \cdot \dot{v i s j}$ & $.74 \pi$ & 802.4 & 26780. & 422.30 & .0167 & 801.1 & . v16i & $.746 \equiv$ \\
\hline
\end{tabular}




\title{
APPENDIX A: INSTRUMENTED MECHANICAL TEST DATA FOR ALL SPECIMENS
}

\section{(continued)}

\author{
LOCNEED MISSILES \& SPALE CD. \\ HATEIRLS \& PROCESSES ENGINERING \\ CEPT. $79-30$
}

3 Point Cosoressive Tegt $-5, i$, Units, Fän Data

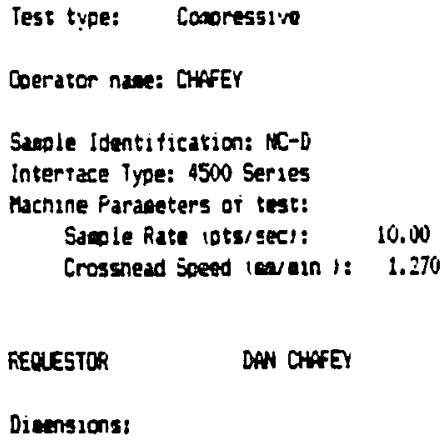

out of 10 soecipens. 4 excluded.

\begin{tabular}{|c|c|c|c|c|c|c|c|c|c|c|}
\hline $\begin{array}{l}\text { Soeciaen } \\
\text { Nueber }\end{array}$ & 10: & $\begin{array}{c}\text { Disolesent } \\
\text { 2t } \\
\text { Max.Load } \\
1=1\end{array}$ & $\begin{array}{l}\text { Load } \\
\text { at } \\
\text { Max.Loat } \\
\text { (BA) }\end{array}$ & $\begin{array}{c}\text { Stress } \\
\text { at } \\
\text { Max.Load } \\
\text { (MPa) }\end{array}$ & $\begin{array}{l}\text { (Autroung) } \\
\text { (Fea) }\end{array}$ & $\begin{array}{l}\text { Stress } \\
\text { at offeat } \\
\text { rield } 1 \\
\text { (roa) }\end{array}$ & $\begin{array}{l}\text { Strasn } \\
\text { at oftent } \\
\text { rislo I } \\
\text { (exura }\end{array}$ & $\begin{array}{l}\text { Stress } \\
\text { at ueser } \\
\text { Breax } \\
(\mathrm{PPA})\end{array}$ & $\begin{array}{l}\text { Strain } \\
\text { de uspr } \\
\text { Break } \\
\text { isay }\end{array}$ & $\begin{array}{l}\text { Load } \\
\text { at user } \\
\text { Break } \\
(\mathrm{KN})\end{array}$ \\
\hline 1 & $\mathrm{Cl}$ & 2.616 & .6405 & 684.5 & 82000. & 217.7 & .0146 & 694.5 & .0146 & .6405 \\
\hline 2 & $M=2$ & 2.591 & .6359 & $6 \pi .3$ & 82640. & 244.4 & .0145 & 676.5 & .0144 & .6331 \\
\hline 3 & $\mathrm{kes}$ & 3.607 & .6566 & 701.6 & 02720. & 250.7 & .0148 & 698.9 & .0148 & $.054 !$ \\
\hline 4 & $\mathrm{NC4}$ & 2.845 & .6998 & 746.7 & 84470. & 300.6 & .0158 & 745.7 & .0159 & .6978 \\
\hline 5 & Mes & 2.469 & .6112 & 653.1 & 82740. & 246.2 & .0140 & 651.0 & .0139 & .6093 \\
\hline 6 & $\mathrm{NDI}$ & 2.489 & .6219 & 604.5 & 83040. & 140.0 & .0140 & $\infty 2.1$ & .0139 & .0196 \\
\hline$i$ & 102 & 2.042 & .0506 & 695.4 & EeTso. & 119.5 & .0147 & 092.9 & .0146 & .0464 \\
\hline$\theta$ & $\tan$ & 2.591 & .0343 & 677.8 & G0010. & 580.1 & .0126 & 675.4 & .0144 & .6321 \\
\hline 9 & No4 & 2.007 & .6481 & 692.5 & 27530. & 243.4 & .0148 & 691.5 & .0148 & .6471 \\
\hline 10 & Nos & 2.718 & .0068 & 712.5 & 84390. & 255.9 & .0151 & 709.6 & .0150 & .0040 \\
\hline Means & & 2.631 & $.646 j$ & 690.0 & 68990. & 258.7 & .0145 & 609.8 & .0146 & $.64+6$ \\
\hline \multicolumn{11}{|l|}{ Standard } \\
\hline Deviation: & & .100 & .0246 & 26.3 & 1029. & 127.0 & .0009 & 26.4 & .00066 & .0247 \\
\hline Minicua: & & 2.489 & .0112 & 653.1 & 80910. & 119.5 & .0126 & 651.0 &.$\dot{1} 139$ & .0093 \\
\hline Maxiauan: & & 2.843 & .0988 & 746.7 & 84470. & 388.1 & .0158 & $745 . i$ & .0158 & .0978 \\
\hline
\end{tabular}




\title{
APPENDIX A: INSTRUMENTED MECHANICAL
}

\section{TEST DATA FOR ALL SPECIRENS}

\author{
(continued)
}

\author{
LOCAREDD MISSILES \& FPHCE CO. \\ MATERILLS \& PROCEĖES ENGINEERING \\ DEST. TE-JO
}

¿ Foint Coosuressive Test-j. L. Units, Kam Data

Test type: Coesressive

Coerator naet: QuFFEY

Saople Identification: $\alpha-1$

Intertace Type: 4500 Series

Machine Parmeters of test: Samole Rate 10t5isec1: 10.00 irossnesd jpeed 1eemern 1: 1.270
Instron Corporation

Series IX hutonted Materials Testing Jystea 1.168 Test Date: 09 Feb 1993

Sapple Type: ASTh

Huandoity 1: 1: 50

iemperature (deg. F): $\quad 3$

REQUESTOR DAN CHFFE:

Ditensions:

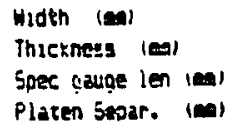

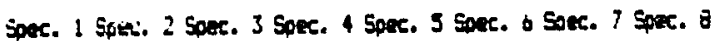

$\begin{array}{lllllllll}12.700 & 12.700 & 12.700 & 12.700 & 12.700 & 12.700 & 12.700 & 12.700\end{array}$

$\begin{array}{llllllll}2.3400 & 2.3400 & 2.3400 & 2.3400 & 2.3440 & 2.3400 & 2.3400 & 2.3400\end{array}$

$\begin{array}{llllllllllll}50.800 & 50.800 & 50.800 & 50.800 & 50.800 & 50.800 & 50.800 & 50.800\end{array}$

101.00101 .00 101.00 101.60 101.00101 .00101 .60101 .60

Out of 10 soecioms, is excluded.

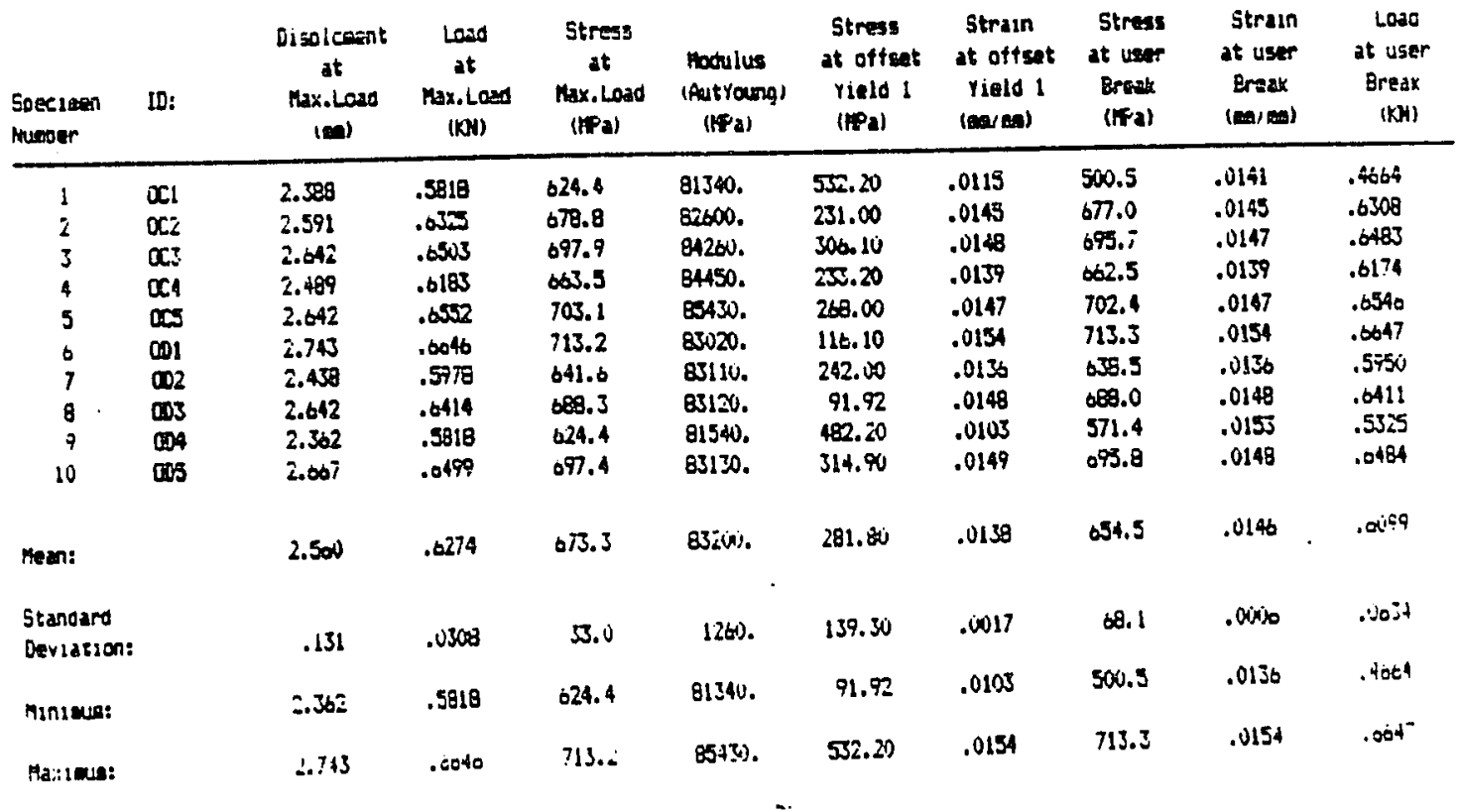




\title{
APPENDIX A: INSTRUMENTED MECHANICAL TEST DATA FOR ALL SPECIA⿵NA \\ (continued)
}

\author{
LOCHEED MISSILES \& SPACE CO.

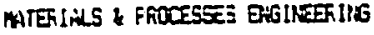 \\ DEFT. 7E-3i \\ 3 foint Comoressive iest-5.1. Units. Ram Data
}

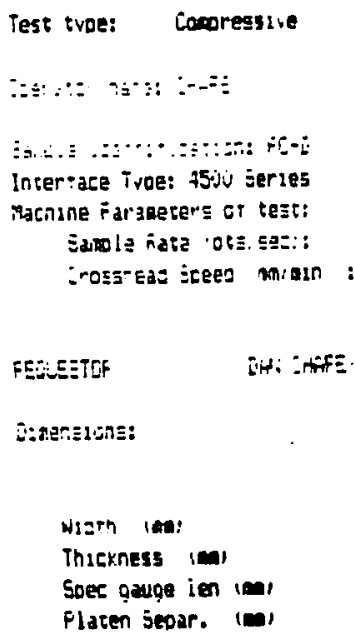

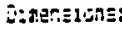

\begin{tabular}{|c|c|c|c|c|c|c|c|c|c|c|}
\hline $\begin{array}{l}\text { Speciaen } \\
\text { pueder }\end{array}$ & ID: & $\begin{array}{l}\text { Disolesent } \\
\text { at } \\
\text { hax.L020 } \\
\text { (as) }\end{array}$ & $\begin{array}{l}\text { Losd } \\
\text { at } \\
\text { Max.Loxd } \\
\text { (kH) }\end{array}$ & $\begin{array}{l}\text { Stress } \\
\text { at } \\
\text { hax. } \\
\text { (KPa) }\end{array}$ & $\begin{array}{l}\text { moculus } \\
\text { (Autroung) } \\
\text { (Fi a) }\end{array}$ & $\begin{array}{l}\text { Stress } \\
\text { at offset } \\
\text { yield } 1 \\
\text { (Fa) }\end{array}$ & $\begin{array}{l}\text { Strain } \\
\text { at offset } \\
\text { rield I } \\
\text { teares }\end{array}$ & $\begin{array}{l}\text { Stress } \\
\text { at usot } \\
\text { Breash } \\
\text { (tfal }\end{array}$ & 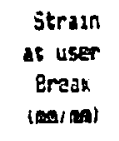 & $\begin{array}{l}\text { Load } \\
\text { at user } \\
\text { Break } \\
(k N)\end{array}$ \\
\hline 1 & $\mathrm{FCl}$ & 2.515 & .6272 & 653.5 & 81730. & 291.4 & .0140 & $65 . .7$ & .0140 & .0265 \\
\hline 2 & Fi2 & 2.515 & .0380 & $t \leq 5.6$ & B294u. & 555.5 & .0141 & 648.3 & .0162 & .623 \\
\hline 3 & PCJ & 2.413 & .6174 & 643.5 & 02190. & 502.2 & .0155 & 302.2 & .0135 & .5895 \\
\hline 4 & $P C 4$ & 2.438 & .0272 & 653.5 & 82500. & 465.8 & .0098 & 650.9 & b13b & .6247 \\
\hline 5 & PCS & 2.042 & $.574 i$ & 598.8 & T98\%O. & 499.0 & .0122 & 396.7 & .0147 & . 5720 \\
\hline 0 & POI & 2.515 &.$\Delta 22$ & 653.5 & Blau. & 500.3 & .0140 & 650.0 & .0140 & .6238 \\
\hline 7 & $P D 2$ & 2.413 & .6072 & b32.: & 80010. & 2505.8 & .0135 & \$1.9 & .0135 & .0004 \\
\hline 8 & PDJ & 2.667 & .6846 & 713.3 & $24 j 3 i$. & 194.5 & .0150 & 711.3 & .0149 & .6826 \\
\hline 9 & $P X$ & 2,565 & . & 096.0 & उ360. & 299.4 & .0144 & 693.9 & .0143 & . \\
\hline 10 & POS & 2.413 & .6147 & 640.5 & B⿺辶一兀0. & 38.1 & .0134 & 657.0 & .0154 & .0121 \\
\hline Mesn: & & 2.510 & .6288 & 655.1 & $2 \mathrm{NO}_{0} 2 \mathrm{O}$. & 378.3 & .0134 & 643.6 & .0142 & .0177 \\
\hline $\begin{array}{l}\text { Stznoard } \\
\text { Deviation: }\end{array}$ & & .093 & . issco & 32.1 & 1555. & 155.0 & .0014 & 42.0 & .0009 & . \\
\hline Minzeua: & & 2.412 & .5747 & 598.8 & TPari. & 194.5 & .0098 & 502.2 & .0134 & .5395 \\
\hline Maxisue: & & $2 . \infty 7$ & 648. & 713.3 & (5)(1). & $5 \sin .2$ & $.015 j$ & 711.3 & .0162 & .6625 \\
\hline
\end{tabular}

5sec. : Eser. : Joer. : soec. 4 Soec. 5 joec. o Soec. 7 Soec. a

$\begin{array}{llllllll}12.700 & 12.700 & 12.700 & 12.700 & 12.700 & 12.700 & 12.700 & 12.700\end{array}$

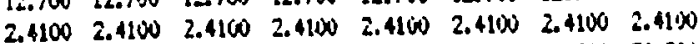

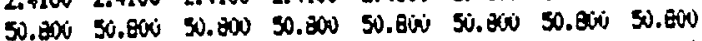
$101.01 \quad 101.00101 .00101 .00101 .00101 .00 \quad 101.00101 .00$ 


\title{
APPENDIX A: INSTRUMENTED MECHANICAL TEST DATA FOR ALL SPECIMENS \\ (continued)
}

\author{
LCCYYED MISSILEE \& SPHCE CO. \\ MATEFIALS \& FFOCEZEES ERGINEETING \\ DEF'T. ' $8-30$
}

इ Fount Cororessi.e Test-5.1. Units. Ran Lata

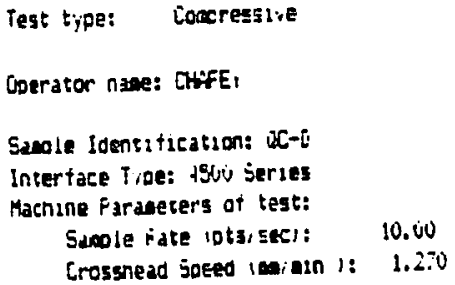

Disensions:

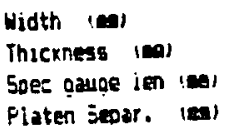

\begin{tabular}{|c|c|c|c|c|c|c|c|c|c|c|}
\hline $\begin{array}{l}\text { Soeciaen } \\
\text { Riveber }\end{array}$ & 10: & $\begin{array}{c}\text { Disolenene } \\
\text { at } \\
\text { Maxiloas } \\
\text { (cos) }\end{array}$ & $\begin{array}{l}\text { Load } \\
\text { at } \\
\text { Max.Loso } \\
\text { (KN) }\end{array}$ & $\begin{array}{l}\text { Stress } \\
\text { at } \\
\text { Man.load } \\
\text { (tfal }\end{array}$ & $\begin{array}{l}\text { Modulus } \\
\text { (itutrounạ) } \\
\text { (Ffa) }\end{array}$ & $\begin{array}{l}\text { Stress } \\
\text { at otrset } \\
\text { neld I } \\
\text { (nfa) }\end{array}$ & $\begin{array}{l}\text { Strain } \\
\text { at ofteat } \\
\text { rield I } \\
\text { (mavel }\end{array}$ & 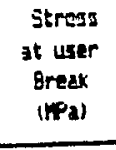 & $\begin{array}{c}\text { Strasn } \\
\text { at user } \\
\text { Brear. } \\
\text { Isay ana }\end{array}$ & 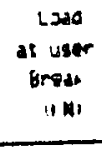 \\
\hline 3 & $\infty^{3}$ & i. 485 & $\begin{array}{l}.6577 \\
.6601\end{array}$ & 667.7 & $\begin{array}{l}82630 . \\
8330.1 .\end{array}$ & $\begin{array}{l}365.2 \\
496.9\end{array}$ & $\begin{array}{l}.0139 \\
.0139\end{array}$ & $600 .:-$ & . & . \\
\hline 4 & $\infty$ & i. 485 & $\begin{array}{l}.6641 \\
.084 t 0\end{array}$ & 668.4 & $\begin{array}{l}2336.1 . \\
02500 .\end{array}$ & $\begin{array}{l}496.9 \\
554.1\end{array}$ & $\begin{array}{l}.0139 \\
.0144\end{array}$ & 542.0 & $\begin{array}{l}.0151 \\
.01+4\end{array}$ & : \\
\hline 5 & $\infty$ & 2.505 & .0840 & $\begin{array}{l}693.2 \\
\infty 67.1\end{array}$ & $\begin{array}{l}\text { Q3500. } \\
\text { E2170. }\end{array}$ & $\begin{array}{l}354.1 \\
331.9\end{array}$ & $\begin{array}{l}.0144 \\
.0141\end{array}$ & 082.6 & $\begin{array}{l}.0144 \\
.0141\end{array}$ & $.00+4:$ \\
\hline$i$ & 201 & 2.515 & $\begin{array}{l}.09598 \\
.092 !\end{array}$ & $\begin{array}{l}\infty 7.1 \\
700.8\end{array}$ & $\begin{array}{l}82170 . \\
84050 .\end{array}$ & $\begin{array}{l}331.9 \\
387.8\end{array}$ & $\begin{array}{l}.0141 \\
.0143\end{array}$ & $\infty 0^{2} .2$ & . & $\begin{array}{l}.0280 \\
.0700\end{array}$ \\
\hline $\bar{i}$ & $\begin{array}{l}0.2 \\
0.03\end{array}$ & $\begin{array}{l}2.505 \\
2.464\end{array}$ & $\begin{array}{l}.082 ! \\
.6500\end{array}$ & $\begin{array}{l}700.8 \\
064.8\end{array}$ & $\begin{array}{l}84055^{\circ} . \\
83870 .\end{array}$ & 352.3 & $\begin{array}{l}.0143 \\
.0151\end{array}$ & $\begin{array}{l}079.3 \\
603.9\end{array}$ & .0157 & רol \\
\hline 9 & ass & 2.645 & .540 & ai.j & 3ुsक. & 550 & .015 & oci. 8 & .0159 & : \\
\hline 10 & 201 & $2.6 \$ 2$ & .7028 & 711.0 & $8<070$. & 247.1 & .0147 & 710.7 & .0147 & \\
\hline Means & & 2.500 & $.60 \dot{ }$ & 676.9 & 83100. & $396 . \div$ & .0137 & 652.2 & $.41+5$ & $.24+1$ \\
\hline Stanaard & & & & & & & & & & \\
\hline Deviacacn: & & .122 & .0256 & 26.0 & 1155. & 101.9 & .0008 & 67.7 &.$i w i j$ & $\ldots \infty:$ \\
\hline Minieua: & & $=.413$ & .0170 & 624.7 & 80670. & 247.1 & .0118 & 515.7 & .015 & $\therefore:=$ \\
\hline & & $\therefore 245$ &. & ;11.s & $340 \% \%$ & 550.0 & $\therefore 7^{\circ}$ & $: 10 .:$ & $.015=$ & . $1:$ \\
\hline
\end{tabular}

Instron ioroorarion Series IX futomateo haterials iesting̣ justea 1.08 Test Dase: 10 feb loq3 $^{2}$

Sacole Trpo: ASTH

Heasosty 1:: : 50 Texperature (ceq. F): is
Soec, 1 Soer. 2 ipec. 3 soec. 4 ipec. 5 5oer. o Soec. 7 Soec. 8

$\begin{array}{llllllll}12.700 & 12.700 & 12.700 & 12.700 & 12.700 & 12.700 & 12.700 & 12.700\end{array}$

$\begin{array}{llllllll}2.4800 & 3.4800 & 2.4800 & 2.4800 & 2.4600 & 2.4800 & 2.4800 & 2.4800\end{array}$

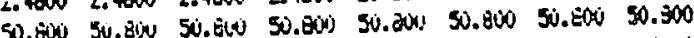

$101.0101 .00101 .00 \cdot 101.00101 .00$ lúl.00 101.00101 .00 


\title{
APPENDIX A: INSTRUMENTED MECHANICAL TEST DATA FOR ALL SPECIMENS \\ (continued)
}

\author{
LOCKEET MISSILES \& SFAE CD. \\ MATEEIALS \& FRCCESES QRSIRERIHG \\ IEFT. TE-jo \\ : Fount ionoresミi.e Teet-j.j. Unıtj, fan Lata
}

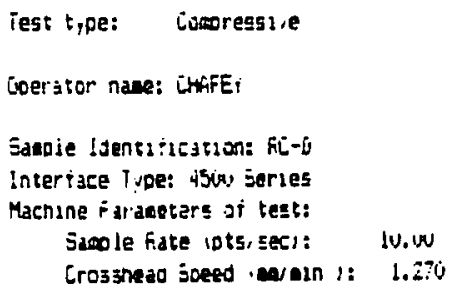

Gisensım:

\begin{tabular}{|c|c|c|c|c|c|c|c|c|}
\hline width & 12. 700 & 12.700 & 12.700 & 12.700 & 12.700 & 12.700 & 12.700 & $1=.30$ \\
\hline Cxne3s & 2.3400 & 2.3400 & 2.3400 & $\therefore 3400^{\circ}$ & 2.3400 & 2.3400 & $\therefore 3400$ & $2.3+200$ \\
\hline (m) & 50.800 & 50.800 & 30.800 & 50.800 & 50.2000 & Siv. 300 & 50.800 & 50.800 \\
\hline :an & 101.00 & 101.60 & 101.60 & lu1.0U & 101.00 & 101.91 & 101.00 & 101.00 \\
\hline
\end{tabular}

Cut of 10. soecideens. is exciuder.

Sacole ccoments: vi: FE, FILL DIFECTIDA SAPLES

\begin{tabular}{|c|c|c|c|c|c|c|c|c|c|c|}
\hline $\begin{array}{l}\text { Scosinen } \\
\text { mumber }\end{array}$ & ID: & $\begin{array}{l}\text { Disolcsent } \\
\text { at } \\
\text { Max.Losd } \\
\text { :eo }\end{array}$ & $\begin{array}{l}\text { Load } \\
\text { at } \\
\text { Mas.Lo2o } \\
\text { (KH) }\end{array}$ & $\begin{array}{l}\text { Stress } \\
\text { at } \\
\text { Max.Lodo } \\
\text { (Mreal }\end{array}$ & $\begin{array}{l}\text { nodulus } \\
\text { (Autrounge! } \\
\text { (If a) }\end{array}$ & $\begin{array}{l}\text { Stress } \\
\text { at offset } \\
\text { relo } 1 \\
\text { iral }\end{array}$ & $\begin{array}{l}\text { Strain } \\
\text { at otiset } \\
\text { tweid ! } \\
\text { reacen }\end{array}$ & $\begin{array}{l}\text { Stress } \\
\text { at user } \\
\text { Erean } \\
\text { (tra) }\end{array}$ & $\begin{array}{c}\text { Strian } \\
\text { at user } \\
\text { ireak. } \\
\text { (soico) }\end{array}$ & $\begin{array}{c}\text {-odo } \\
\text { at user } \\
\text { Break } \\
\text { (|H) }\end{array}$ \\
\hline 1 & $\mathrm{FCl}$ & j.3iv & $.76 \pi$ & 623.4 & 8193ن. & 811.00 & .0170 & e2.? & .0178 & . \\
\hline 2 & FE: & 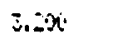 & .7902 & 654.5 & 54310 & 24.21 & .0179 & 850.4 & .0179 & .7952 \\
\hline$?$ & FC: & 3.51 & 年. & 60.7 & 84020. & 813.00 & .0173 & BSt.J & .0182 & 年. \\
\hline 4 & $\mathrm{RCI}$ & 3.251 & .8150 & 875.5 & asstiv. & 49.07 & .0181 & 873.2 & .uेl8! & .8128 \\
\hline 5 & FES & j. & .8008 & 867.3 & Bostij. & $828.0 \mathrm{w}$ & .0171 & 864.3 & 政. & ? \\
\hline - & ROI & $3.2 \pi$ & .8154 & 995.1 & 86960. & 24.29 & $.018:$ & Qivt.o & .0192 & .8430 \\
\hline 7 & $F D=$ & 3.124 & $.80 \pi$ & 863.1 & 65200. & 23.72 & .0175 & 859.1 & .0174 & .8015 \\
\hline 8 & 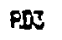 & $2.05 ?$ & .7713 & 827.7 & 87340. & 48.23 & .0167 & 820.9 & $.016 i$ & .77is \\
\hline 9 & Fin & 3. & $.794 j$ & 852.1 & 85730. & 109. ii & . & 849.0 & $.01 \%$ & : \\
\hline 10 & FOS & $3.27 ?$ & . & 890.7 & Bolsi. & 134.20 & .0182 & 893.6 & 苂181 & $.5=57$ \\
\hline He:an: & & 3.168 & . & BSz. 0 & EsT.u. & 200.00 & .0176 & 860.2 & .0178 & .8016 \\
\hline \multicolumn{2}{|l|}{ jtanoard } & & & & & & & & & \\
\hline \multicolumn{2}{|l|}{ De.tatien: } & رب9. & . 2243 & 26.1 & 1000. & 380.20 & $.0 x i s$ & 3.8 & .0005 & $.1) \leq+i$ \\
\hline \multicolumn{2}{|l|}{ M1ก1 aนd: } & 2.537 & $\therefore$ & & 81:30. & 23.92 & .0167 & 82.9 & $.016 ?$ & .7068 \\
\hline Mz:istum: & & $3.2 \pi$ & .845t & 900.1 & $8 \pi, 40$. & 828.00 & .0182 & 904.0 & $.018 i$ & $.04 \pi$ \\
\hline
\end{tabular}




\title{
APPENDIX A: INSTRUMENTED MECHANICAL TEST DATA FOR ALL SPECIMENS
}

\section{(continued)}

\author{
LOCXHEED MISSILES \& SPALE CO. \\ MATEFIHLS \& FFOCESEES BUGINEETING \\ DEFT. 78-30 \\ ¿ Fant Leopressive Test-5.l. Unats.Fia Data

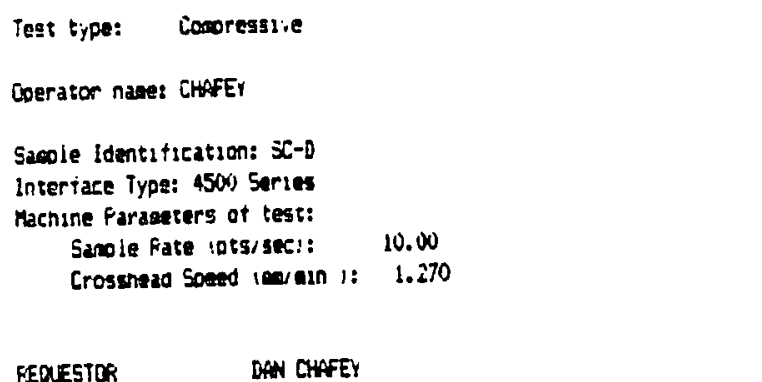

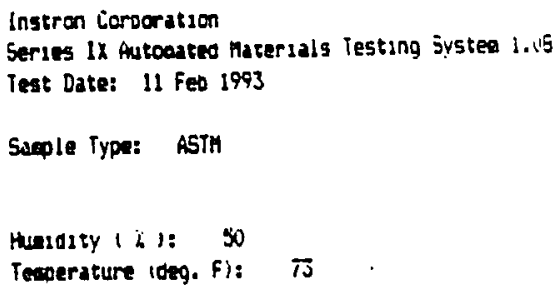 \\ FEOLSTDR DAN CHAFEY
}

Diensions:

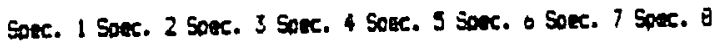

\begin{tabular}{|c|c|c|c|c|c|c|c|c|}
\hline \multirow{3}{*}{ 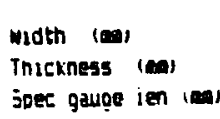 } & & & & & & & & \\
\hline & 2.37000 & . 57000 & 2 & $\infty 0$ & $2.5700)$ & 2.5700 & 2.5700 & 2.5700 \\
\hline & 50.800 & 50.8000 & 30.800 & $\infty$ & $(x$ & 50.800 & 50.200 & 50.2000 \\
\hline & & & & & & & & \\
\hline
\end{tabular}

Out of 10 soeciens. is excluaed.

sanole coesents: $\therefore .18 \%$ FEF, FIL DIFECTION SNFLES

\begin{tabular}{|c|c|c|c|c|c|c|c|c|c|c|}
\hline $\begin{array}{l}\text { Soecigen } \\
\text { Nheoser }\end{array}$ & 10: & $\begin{array}{l}\text { Displement } \\
\text { at } \\
\text { Max.Losd } \\
\text { Iad }\end{array}$ & $\begin{array}{l}\text { Losd } \\
\text { at } \\
\max . \text { Losd } \\
\text { (KN) }\end{array}$ & $\begin{array}{l}\text { Streas } \\
\text { at } \\
\text { Max.Load } \\
\left(F_{2}\right)\end{array}$ & $\begin{array}{l}\text { Hoculus } \\
\text { (Pautrourg) } \\
\text { (PPa) }\end{array}$ & $\begin{array}{l}\text { Stress } \\
\text { at offeat } \\
\text { Yield } 1 \\
\text { (FFa) }\end{array}$ & $\begin{array}{l}\text { Strain } \\
\text { at offeet } \\
\text { field } 1 \\
\text { imimal }\end{array}$ & $\begin{array}{l}\text { Stress } \\
\text { at user } \\
\text { Break } \\
\text { (fira) }\end{array}$ & $\begin{array}{c}\text { Strain } \\
\text { at user } \\
\text { Break } \\
\text { Inas iso }\end{array}$ & $\begin{array}{l}\text { Loado } \\
\text { at user } \\
\text { Ereak } \\
(k \mathrm{~N})\end{array}$ \\
\hline 1 & $x$ & 2.464 & .0259 & 663.1 & 81810. & 51.7 & .0156 & 42.8 & .0178 & $.6=56$ \\
\hline 2 & $5 C 2$ & 2.616 & .6580 & 698.0 & 83600. & 170.0 & .0186 & 698.8 & .0145 & .6551 \\
\hline 3 & $s$ & 2.042 & .5689 & 602.8 & soveo. & 497.7 & .0122 & 000.5 & .0147 & $.500 i$ \\
\hline 4 & $\subseteq 4$ & 2.413 & .0085 & 644.7 & 83110. & 264.2 & .0135 & 642.4 & .0134 & .6063 \\
\hline 3 & 505 & 2.043 & .0993 & 740.9 & 80000. & 266.0 & .0153 & 738.8 & .0152 & .0975 \\
\hline 0 & 501 & 2.769 & .7050 & 747.0 & 86520. & 192.3 & .0155 & 743.9 & .0154 & .7021 \\
\hline 7 & 502 & 2.571 & .6518 & 889.5 & E2410. & 305.0 & .0144 & $\Delta 89.0$ & .0194 & $.05 \mathrm{ij}$ \\
\hline 8 & 503 & 2.972 & .7477 & 792.3 & 850001. & $\infty 3.7$ & .0165 & 663.7 & .0165 & .0264 \\
\hline 9 & 54 & 2.643 & .7255 & $708 .:$ & $838 i$. & 170.8 & .0159 & 767.1 & .0157 & .2240 \\
\hline 10 & 303 & 2.010 & $.065 i$ & 704.0 & Bsilu. & 386.0 & .0146 & 703.3 & .0146 & .0038 \\
\hline Men: & & 2.067 & .0653 & 708.2 & 84290 & 317.6 & .0146 & 070.6 & .0148 & $.551 E$ \\
\hline $\begin{array}{l}\text { Stanaard } \\
\text { Deyzation: }\end{array}$ & & .169 & . & 59.5 & 3560. & 158.1 & .0013 & 50.7 & .0109 & $.04 \pi^{\circ}$ \\
\hline Arnieun: & & 2.413 & .5689 & 602.8 & 80080. & 170.0 & .0122 & 600.5 & .0174 & .5607 \\
\hline Maximas: & & 2.972 & .7477 & $792 .:$ & $\operatorname{secico.}$ & 663.7 & .0165 & 767.1 & .0165 & .7:H \\
\hline
\end{tabular}




\title{
APPENDIX A: INSTRUMENTED MECHANICAL \\ TEST DATA FOR ALL SPECMENS \\ (continued)
}

\author{
LOOHEED MISSILES $\&$ FALE CO.

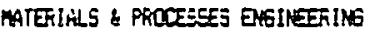 \\ DEFT. 79-30
}

3 Point Cosoressive Test-s. L. Inits, Fam Iiata

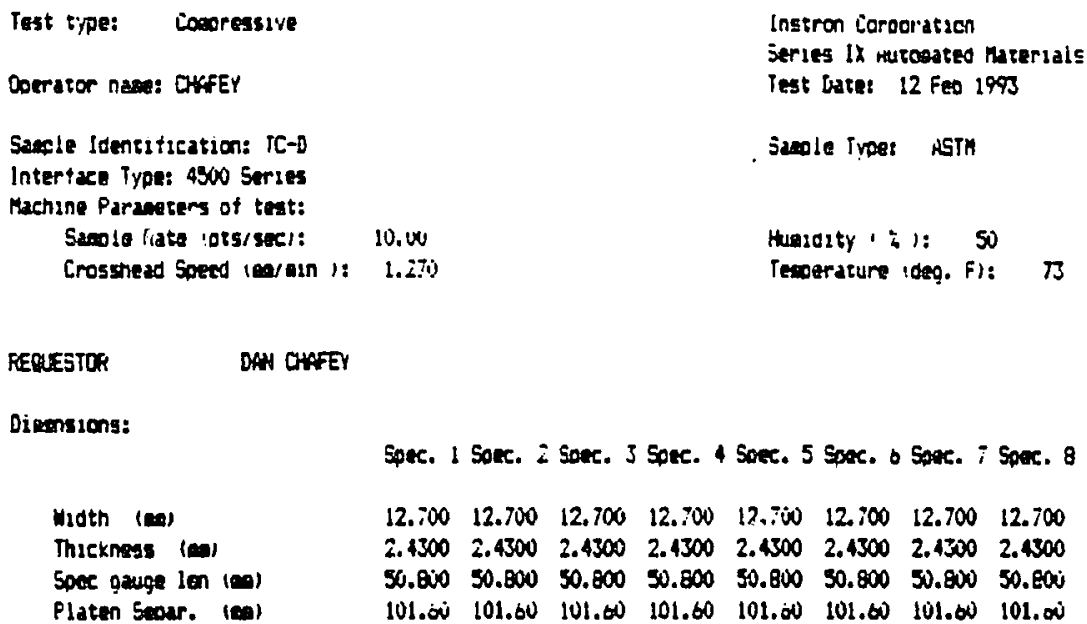

Out of 10 soceimens. 0 excluosed.

Sarole coments: 4.08\% FEP, FILL DIFECTION SAPLES

\begin{tabular}{|c|c|c|c|c|c|c|c|c|c|c|}
\hline $\begin{array}{l}\text { Sptecinas } \\
\text { Heser }\end{array}$ & 10: & $\begin{array}{l}\text { Disolcomt } \\
\text { at } \\
\text { hax.Land } \\
\text { (ص) }\end{array}$ & $\begin{array}{l}\text { Losd } \\
\text { at } \\
\text { Mx.Loxd } \\
\text { (kH) }\end{array}$ & $\begin{array}{l}\text { Strass } \\
\text { at } \\
\text { Max.Lodo } \\
\text { (roa) }\end{array}$ & $\begin{array}{l}\text { Moctulus } \\
\text { (Attroung) } \\
\text { (PPa) }\end{array}$ & $\begin{array}{l}\text { Stress } \\
\text { at offset } \\
\text { yield } 1 \\
\text { (10a) }\end{array}$ & $\begin{array}{l}\text { Strain } \\
\text { at oftret } \\
\text { rield I } \\
\text { lemes }\end{array}$ & $\begin{array}{l}\text { Stress } \\
\text { di user } \\
\text { Breax } \\
\text { (1Fa) }\end{array}$ & $\begin{array}{c}\text { Strain } \\
\text { at usar } \\
\text { Break } \\
t=0 / 01\end{array}$ & $\begin{array}{l}\text { Loso } \\
\text { at user } \\
\text { Brear } \\
\text { (kN) }\end{array}$ \\
\hline 1 & $\pi$ & 2.413 & .0525 & 653.0 & 84050. & 381.5 & .0135 & 544.1 & .0194 & .5205 \\
\hline 2 & $i n$ & 2.362 & . & 644.7 & 39556. & 369.2 & .0132 & 55.0 & .0190 & $.5 i 73$ \\
\hline 3 & ICS & 2.642 & .6997 & 725.1 & 204600 & 200.5 & .0147 & 719.0 & $.01 \&_{b}$ & .0504 \\
\hline 4 & TCA & 2.692 & .7211 & 745.1 & 86470. & 377.1 & .0150 & 745.0 & .0150 & .7209 \\
\hline 5 & $T E$ & 2.515 & . 8939 & 717.1 & $87 \times 90^{\circ}$ & 524.9 & .0141 & 714.2 & .0140 & .6912 \\
\hline$b$ & TDI & 2.616 & .0961 & $? 19.4$ & 86900 . & 162.7 & .0147 & 717.2 & .0146 & .0941 \\
\hline 7 & $\mathrm{TD2}$ & 2.607 & .7148 & 733.7 & 86370 & 261.7 & .0149 & $T 37.2$ & .0149 & .7134 \\
\hline$\theta$ & TOS & 2.616 & .6917 & 714.8 & 88010. & 216.0 & .0146 & 713.5 & .0146 & .6904 \\
\hline 9 & TDA & 2.389 & .6179 & 638.5 & 83040. & 579.2 & .012 & 036.2 & ت 015. & .6150 \\
\hline 10 & TOS & 2.515 & .6583 & 60.3 & 34s5i. & 242.8 & .0141 & 077.4 & .0140 & .0550 \\
\hline ורש: & & 2.543 & .6750 & 677.5 & 85820. & $368 .:$ & .0141 & $6 \pi 3.9$ & .0153 & .6322 \\
\hline \multicolumn{11}{|l|}{ Standard } \\
\hline Deviations & & .126 & .0388 & 39.8 & 1722 & 124.1 & .0009 & $\pi .3$ & .0021 & .0748 \\
\hline Hinioun: & & 2.362 & .0179 & 638.5 & 83040. & 210.6 & .0122 & 530.0 & .0133 & .5179 \\
\hline Maxioua: & & 2.692 & .7211 & 785.1 & 88010. & 579.3 & .0130 & 745.0 & .0194 & .7209 \\
\hline
\end{tabular}

